The quality of this microform is heavily dependent upon the quality of the original thesis submitted for microfilming. Every effort has been made to ensure the highest quality of reproduction possible.

If pages are missing, contact the university which granted the degree.

Some pages may have indistinct print especially if the original pages were typed with a poor typewriter ribbon or if the university sent us an inferior photocopy.

Reproduction in full or in part of this microform is governed by the Canadian Copyright Act, R.S.C. 1970, c. C-30, and subsequent amendments.
La qualité de cette microforme dépend grandement de la qualité de la thèse soumise au microfilmage. Nous avons tout fait pour assurer une qualité supérieure de reproduction.

S'il manque des pages, veuillez communiquer avec l'université qui a conféré le grade.

La qualité d'impression de certaines pages peut laisser à désirer, surtout si les pages originales ont été dactylographiées à l'aide d'un ruban usé ou si l'université nous a fait parvenir une photocopie de qualité inférieure.

La reproduction, même partielle, de cette microforme est soumise à la Loi canadienne sur le droit d'auteur, SRC 1970, c. C-30, et ses amendements subséquents. 
TOXICITY TESTING OF REFINERY WASTEWATER

USING MICROTOX

\author{
A Thesis \\ Submitted to the Faculty of Graduate Studies and Research \\ In Partial Fulfillment of the Requirements \\ for the Degree of \\ Master of Applied Science \\ in Regional Environmental Systems Engineering \\ University of Regina
}

by

John Antony Aruldoss

Regina, Saskatchewan

June, 1995

(C) Copyright 1995: J.A.Aruldoss 
The author has granted an irrevocable non-exclusive licence allowing the National Library of Canada to reproduce, loan, distribute or sell copies of his/her thesis by any means and in any form or format, making this thesis available to interested persons.

The author retains ownership of the copyright in his/her thesis. Neither the thesis nor substantial extracts from it may be printed or otherwise reproduced without his/her permission.
L'auteur a accordé une licence irrévocable et non exclusive permettant à la Bibliothèque nationale du Canada de reproduire, prêter, distribuer ou vendre des copies de sa thèse de quelque manière et sous quelque forme que ce soit pour mettre des exemplaires de cette thèse à la disposition des personnes intéressées.

L'auteur conserve la propriété du droit d'auteur qui protège sa thèse. Ni la thèse ni des extraits substantiels de celle-ci ne doivent être imprimés ou autrement reproduits sans son autorisation. 


\section{UNIVERSITY OF REGINA}

\section{FACULTY OF GRADUATE STUDIES AND RESEARCH \\ PERMISSION TO USE POSTGRADUATE THESES}

TITLE OF THESIS: $\quad$ Toxicity Testing of Refinery W-atewater Using Microtox

NAME OF AUTHOR: John Antony Aruldoss

FACULTY: $\quad$ Faculty of Graduate Studies and Research

DEGREE: Master of Applied Science

In presenting this thesis in partial fulfillment of the requirements for a postgraduate degree from the University of Regina, I agree that the Libraries of this University shall make it freely available for inspection. I further agree that permission for extensive copying of this thesis for scholarly purposes may be granted by the professor or professors who supervised my thesis work, or in their absence, by the Head of the Department or the Dean of the Faculty in which my thesis work was done. It is understood that any copying, publication or use of this thesis or parts thereof for financial gain shall not be allowed without my written permission. It is also understood that due recognition shall be given to me and to the University of Regina in any scholarly use which may be made of my material in my thesis.

SIGNATURE:

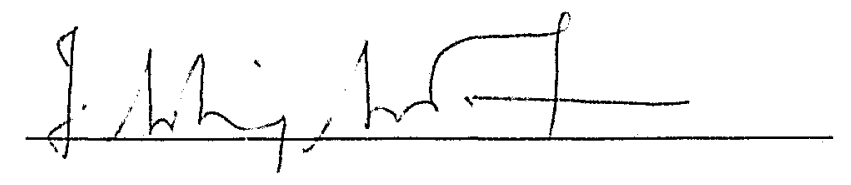

DATE:

$28 / 6 / 95$


UNIVERSITY OF REGINA

FACULTY OF GRADUATE STUDIES AND RESEARCH

CERTIFICATION OF THESIS WORK

We, the undersigned, certify that John Antony Aruldoss, candidate for the Degree of Master of Applied Science has presented a thesis on Toxicity Testing of Refinery Wastewater Using Microtox, that the thesis is acceptable in form and content, and that the student demonstrated a satisfactory knowledge of the field covered by the thesis in an oral examination held on June 28, 1995.

External Examiner:

Internal Examiners:

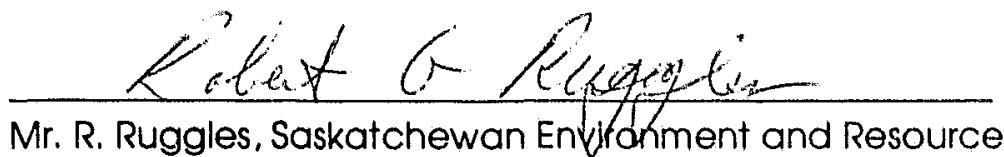

Management

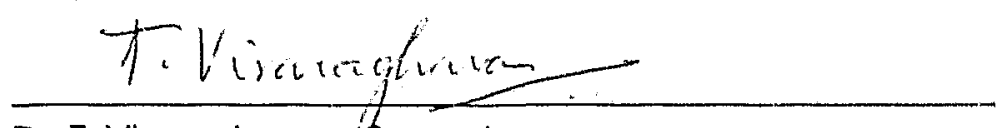

Dr. T. Viraraghavan, Supervisor

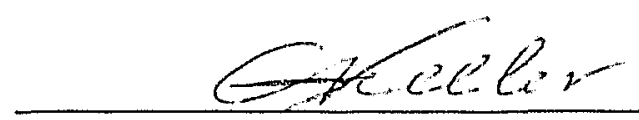




\begin{abstract}
\end{abstract}
'Toxicity' removal from wastewater is one of the manv, but important criteria set by the regulatory authorities with respect to discharge of wastewater into receiving bodies.Although bioassays are regularly used in the identification and monitoring of wastewater, certain difficulties are associated with them. A surrogate for these bioassays would be beneficial in a quick identification of the toxic streams that require immediate attention. Therefore an attempt was made to determine such a surrogate, which is most likely to be one of the wastewater parameters. Due to its composition, lethal nature and the attention provided by regulatory agencies refinery wastewater was selected for this study. Three different type of wastewaters- influent and effluent of American Petroleum Institute (API) separator(a and b) and secondary treated effluent (c) were regularly collected from a nearby refinery (Consumers' COOP refinery Ltd, Regina) and tested for a period of 11 weeks. Microtox which uses a photoluminescent bacteria as a toxicity indicator was used in toxicity identification.Generally, the inhibiting concentrations are expressed as $\mathrm{IC}_{50}$ or $\mathrm{EC}_{50}$ or $\mathrm{LC}_{50}$ represents the concentration that causes mortality and sublethal effects in $50 \%$ of the organisms. $\mathrm{IC}_{50}$ is the concentration at which $50 \%$ of the specified effect gets reduced. As per Canadian regulations, $\mathrm{IC}_{50}$ is used in this bioassay. Specified effect is the respiratory activity of Microtox bioassay, measured as light. Wastewaters associated with API separators were found to be highly toxic. API separator's contribution in toxicity reduction was found to be minimal and inconsistent. $30 \mathrm{~min} \mathrm{IC}_{50}$ wastewater (a) varied between 0.7404 to a maximum of 4.8915 percent of wastewater, whereas 0.8595 to 7.0068 percent was the $30 \mathrm{~min} \mathrm{IC}_{50}$ of wastewater(b). Toxicity of the wastewater (c) was found to be inconsistent. One sample exhibited $30 \mathrm{~min} \mathrm{IC}_{50}$ of 12.7889 percent, which raised some concern. Based on the 1,15 and $30 \mathrm{~min} \mathrm{IC}_{50} \mathrm{~s}$ and trend of wastewater characteristics, organics were predicted to be the toxicity contributors of the final effluent. Statistical analysis between wastewater characteristics and $\mathrm{IC}_{50} \mathrm{~s}$ for tested wastewaters showed 
significant relationships for a few parameters of wastewaters a and c. Chemical oxygen demand, total suspended solids and total dissolved solids are the wastewater parameters that showed significant relationship with $\mathrm{IC}_{50}$ values. This led to the conclusion that these parameters could be considered as surrogates for refinery process wastewater toxicity. 


\section{Acknowledgement}

I am highly indebted to my supervisor Dr.T.Viraraghavan for having given me the oppurtunity to work under him. I am thankful for his invaluable guidance and immense support throughout, in the successful completion of this work and record my whole hearted sense of gratitude to hirn. I would like to thank Dr.P.J.Catania, and Dr.G.A.Fuller for their help in reviewing this thesis.

I appreciate the cooperation of personnel, particularly Mr.Larry Knezacek at Consumers' Co-operative Refineries Limited, Regina for collection and supply of refinery wastewater samples.I acknowledge the help and support of Ms.Helene-Henning Hill, Environmental Engineering Division for this study through a supply of wastewater samples.

This study was supported by an operating grant from the Natural Sciences and Engineering Research Council of Canada (NSERC) to Dr.T.Viraraghavan.I am thankful to the Faculty of Graduate Studies and Research for financial support through the award of teaching assistantship from Jan.1995 to Apr.1995. I would like to thank Dr.Peter Howard, Dept. of Biology, University of Regina for allowing the use of the cold storage room. Work of this type, no matter the magnitude, involve so many people to whom my deep appreciation is due My sincere thanks to Mr.D.McLeod, Mr.R. Sapach, Mr.R.Konduru and Mr.A.Kapoor. Mr.T.V.Swaminathan's help and support during the entire period is greatly appreciated.

At this moment I gratefully acknowledge the help, support, encouragement I had from my parents, brother and sister. My thanks are also due to many teachers who reposed confidence in me and showed me the path. 


\section{Table of Contents}

Abstract $\quad$ i

Acknowledgement iii

Table of Contents iv

List of Tables vi

List of Figures vii

$\begin{array}{ll}\text { Nomenclature } & \text { ix }\end{array}$

1 Introduction 1

1.1 General 1

1.2 Regulatory activities 1

$\begin{array}{ll}1.3 \text { Biological testing } & 3\end{array}$

1.4 Characteristics of petroleum refinery wastewater 4

1.5 Microtox 5

1.6 Surrogate parameters $\quad 7$

$\begin{array}{ll}1.7 \text { Objectives of the study } & 8\end{array}$

$\begin{array}{ll}1.8 \text { Scope of the study } & 8\end{array}$

2 Review of Literature $\quad 9$

2.1 General 9

2.2 Acute toxicity testing of refinery effluents $\quad 10$

2.3 Chronic toxicity testing of refinery effluents 15

2.4 Microtox as an assay in industrial wastewaters 20

2.5 Comparison of Microtox and other bioassays 21

3 Materials and Methods 23 
$\begin{array}{ll}3.1 \text { Wastewater } & 23\end{array}$

$\begin{array}{ll}3.2 \text { Microtox } & 24\end{array}$

3.3 Toxicity studies using Microtox 25

$\begin{array}{lr}3.4 \text { Analytical procedure } & 28\end{array}$

$\begin{array}{ll}3.5 \text { Methods adopted } & 28\end{array}$

4 Results and Discussions 31

4.1 Characteristics of COOP refinery wastewater 31

4.2 Trends observed in refinery wastewater characteristics 31

4.3 Toxicity of refinery wastewater samples 34

4.4 Statistical analysis of $\mathrm{IC}_{50}$ and refinery wastewater characteristics 37

4.5 Discussion on refinery wastewater toxicity 56

4.6 Discussion on statistical analysis of $\mathrm{IC}_{50}$ vs. refinery wastewater 57 parameters

5 Summary, Conclusions and Further Research Needs 62

5.1 Summary 62

$\begin{array}{ll}5.2 \text { Conclusions } & 63\end{array}$

5.3 Further research needs $\quad 63$

$\begin{array}{ll}\text { References } & 64\end{array}$

Appendix .i Microtox data for sample $11(a, b$, and $c) \quad 70$ 


\section{List of Tables}

1.1 Examples of concentrations of refinery wastewater pollutants before and after biological treatment

$4.1 \mathrm{pH}$ of the refinery wastewater samples 32

$4.2 \mathrm{COD}$ of the refinery wastewater samples 32

4.3 TSS of the refinery wastewater samples $\quad 32$

4.4 TDS of the refinery wastewater samples 33

$4.5 \mathrm{NH}_{3}{ }^{+} \mathrm{N}$ of the refinery wastewater samples 33

4.6 TPH of the refinery wastewater samples 33

4.7 Light levels $\left(\mathrm{I}_{\mathrm{t}}\right)$ of refinery wastewaters, using $2 \%$ screening test. 35

$4.8 \mathrm{IC}_{50}$ (in \%) of the refinery wastewater samples 36

4.9 Distribution analysis of the toxicity of refinery wastewater samples 45

4.10 Distribution analysis of the characteristics of refinery wastewater samples $\quad 46$

4.11 Application of wastewater quality parameters for predicting toxicity response (Influent to API separator) $\quad 47$

4.12 Application of wastewater quality parameters for predicting toxicity response (Effluent from API separator) $\quad 48$

4.13 Application of wastewater quality parameters for predicting toxicity response (Effluent from stabilization pond) 


\section{List of figures}

3.1 Wastewater collection and treatment system in COOP refinery ltd, Regina. $\quad 24$

3.2 A photograph showing experimental setup of the present study 26

4.1 Trend in $\mathrm{pH}$ of wastewater samples $\quad 38$

4.2 Trend in COD of wastewater samples $\quad 38$

4.3 Trend in TSS of wastewater samples 39

4.4 Trend in TDS of wastewater samples 39

4.5 Trend in AMM.N of wastewater samples 40

4.6 Trend in TPH of wastewater samples 40

4.7 $\mathrm{IC}_{50}$ for influent to API separator $\quad 41$

4.8 $\mathrm{IC}_{50}$ for effluent from API separator $\quad 42$

$4.9 \mathrm{IC}_{50}$ for effluent from stabilization pond 43

4.10(a) $\mathrm{pH}$ vs. Toxicity values $\mathrm{IC}_{50}$ at contact times $\mathrm{T}=1,15$ and $30 \mathrm{~min}$. for influent to API separator $\quad 50$

4.10(b) $\mathrm{pH}$ vs. Toxicity values $\mathrm{IC}_{50}$ at contact times $\mathrm{T}=1,15$ and $30 \mathrm{~min}$. for effluent to API separator

4.10(c) $\mathrm{pH}$ vs. Toxicity values $\mathrm{IC}_{50}$ at contact times $\mathrm{T}=1,15$ and $30 \mathrm{~min}$. for effluent from stabilization pond

4.11(a) COD vs. Toxicity values $\mathrm{IC}_{50}$ at contact times $\mathrm{T}=1,15$ and $30 \mathrm{~min}$. for influent to API separator

4.11(b) $\mathrm{COD}$ vs. Toxicity values $\mathrm{IC}_{50}$ at contact times $\mathrm{T}=1,15$ and $30 \mathrm{~min}$. for effluent to API separator

4.11(c) COD vs. Toxicity values $\mathrm{IC}_{50}$ at contact times $\mathrm{T}=1,15$ and $30 \mathrm{~min}$. for effluent from stabilization pond

4.12(a) TSS vs. Toxicity values $\mathrm{IC}_{50}$ at contact times $\mathrm{T}=1,15$ and $30 \mathrm{~min}$. for influent to API separator 
4.12(b) TSS vs. Toxicity values $\mathrm{IC}_{50}$ at contact times $\mathrm{T}=1,15$ and $30 \mathrm{~min}$. for effluent to API separator

4,12(c) TSS vs. Toxicity values $\mathrm{IC}_{50}$ at contact times $\mathrm{T}=1,15$ and $30 \mathrm{~min}$. for effluent from stabilization pond

4.13(a) TDS vs. Toxicity values $\mathrm{IC}_{50}$ at contact times $\mathrm{T}=1,15$ and $3 \mathrm{C}$. influent to API separator

4.13(b) TDS vs. Toxicity values $\mathrm{IC}_{50}$ at contact times $\mathrm{T}=1,15$ and $30 \mathrm{~min}$. for effluent to API separator

4.13(c) TDS vs. Toxicity values $\mathrm{IC}_{50}$ at contact times $\mathrm{T}=1,15$ and $30 \mathrm{~min}$, for effluent from stabilization pond

4.14(a) $\mathrm{NH}_{3}{ }^{+} \mathrm{N}$ vs. Toxicity values $\mathrm{IC}_{50}$ at contact times $\mathrm{T}=1,15$ and $30 \mathrm{~min}$. for influent to API separator

4.14(b) $\mathrm{NH}_{3}{ }^{+} \mathrm{N}$ vs. Toxicity values $\mathrm{IC}_{50}$ at contact times $\mathrm{T}=1,15$ and 30 min. for effluent toAPI separator

4.14(c) $\mathrm{NH}_{3}{ }^{+} \mathrm{N}$ vs. Toxicity values $\mathrm{IC}_{50}$ at contact times $\mathrm{T}=1,15$ and 30 min.for effluent from stabilization pond

4.15(a) TPH vs. Toxicity values $\mathrm{IC}_{50}$ at contact times $\mathrm{T}=1,15$ and $30 \mathrm{~min}$. for influent to API separator

4.15(b) TPH vs. Toxicity values $\mathrm{IC}_{50}$ at contact times $\mathrm{T}=1,15$ and $30 \mathrm{~min}$. for effluent to API separator

4.15(c) TPH vs. Toxicity values $\mathrm{IC}_{50}$ at contact times $\mathrm{T}=1,15$ and $30 \mathrm{~min}$. for effluent from stabilization pond 


\section{Nomenclature}

\begin{tabular}{|c|c|}
\hline ARM & Arbitrary reference mixture \\
\hline AOX & Adsorbable organic halogens \\
\hline ASP & Activated sludge process \\
\hline BOD & Biochemical oxygen demand, 5 day, $20^{\circ} \mathrm{C}$ \\
\hline BPT & Best practicable technology \\
\hline COD & Chemical oxygen demand \\
\hline CWA & Clean water act \\
\hline DO & Dissolved oxygen \\
\hline $\mathrm{EC}_{20}$ & Effective concentration causing 20 percent light reduction \\
\hline $\mathrm{EC}_{50}$ & Effective concentration causing 50 percent light reduction \\
\hline EPS & Environmental protection service \\
\hline G6PDH & Glucose-6-phosphate dehydroenose \\
\hline $\mathbf{I}_{0}$ & Initial light reading \\
\hline $\mathbf{I}_{\mathrm{t}}$ & Final light reading \\
\hline$I_{o c}$ & Light level (1) at incubation time(t) of the control (c) \\
\hline $\mathrm{I}_{\mathrm{tc}}$ & Light level (1) at incubation zero time $(0)$ of the control (c) \\
\hline $\mathrm{IC}_{50}$ & Inhibiting concentration causing 50 percent light reduction \\
\hline $\mathrm{LC}_{50}$ & Lethal concentration causing 50 percent mortality \\
\hline NOEC & No observed effective concentration \\
\hline NPDES & National pollutant discharge elimination system \\
\hline $\mathbf{R}_{\mathbf{t}}$ & Correction factor \\
\hline TDS & Total dissolved solids \\
\hline TIE & Toxicity identification evaluation \\
\hline TL & Tolerance limit \\
\hline TOC & Total organic carbon \\
\hline TSS & Total suspended solids \\
\hline TPH & Total petroleum hydrocarbons \\
\hline USEPA & United States Environmental Protection Agency \\
\hline WET & Whole effluent testing \\
\hline $\mathrm{NH}_{3}{ }^{+} \mathrm{N}$ & Ammonia nitrogen \\
\hline$\Gamma$ & Gamma \\
\hline$\% \Delta$ & percent light loss \\
\hline
\end{tabular}




\section{Chapter One}

\section{INTRODUCTION}

\subsection{General}

Discharge of acceptable quantities of effluents from municipal and industrial waste treatment facilities into surface water has long been recognized as a reasonable method for the disposal of wastewaters. The capacity for receiving waters to assimilate such waste without subsequent degradation of water quality is on the decline. It is due to the nature and increase in the quantity of such wastes. Regulatory agencies, aware of the growing public concern over ever increasing environmental hazards started imposing strict regulatory limits on the effluent quality.Mostly, traditional approaches in effluent testing involved specific-chemical analyses. In recent years, the use of biological organisms as an alternative to chemical analysis to determine toxicity of an effluent is on the rise.The reasons are their simplicity, accuracy and above all, cost effectiveness.

\subsection{Regulatory activities}

An important objective of the wastewater toxicity testing is to protect receiving waters (or) treatment plants which use biological processes from adverse impacts. In Canada, for 
many years, the federal and provincial governments regulated discharge limits of industrial effluents, based on fish toxicity testing. In the mid-60s, the province of British Columbia started implementing toxicity standards in pulp and paper mill discharges (Walden et al., 1976). Mostly the effluent toxicity limits were "technology based". That is they were based on data characterizing toxicity of wastes from well operated, treated effluent plants (Walden et al., 1976; Pessah and Cornwall, 1980). Over the years, a point of flexibility in the tests has been observed. From an original limit of $100 \%$ survival in $65 \%$ effluent through a 96-h non static test, for pulp and paper mills (Canada Department of the Environment, 1972) it has been reduced to 80\% survival for the same effluent, by 1972 . Also, toxicity limits were produced for other types of industries. Through the years, test demands were relaxed and by 1980 , the flow through requirements were changed to allow use the of static tests (Pessah and Cornwall, 1980).

In the United States, very few permits with specifications regarding individual components based on effluent toxicity testing have been issued. From early to mid-70s, permits containing toxicity limits for complex effluents have been issued by states such as California and Washington. Till the advent of Clean Water Act (CWA) in 1977, the United States Environmental Protection Agency (USEPA) never issued a permit specifying a complex effluent toxicity target or limit. The CWA made the United States Environmental Protection Agency take up protection of water from discharge of industrial wastewaters and associated pollutants. After the reauthorization of CWA in 1987, the United States Environmental Protection Agercy through the National Pollutant Discharge Elimination System (NPDES) started implementing and enforcing effluent limitations and guidelines, for every point source discharge. 


\subsection{Biological testing}

Chemical specific approach, in combination with models can provide more complete insight into such things as chemical reactivity, biological availability, physiological and toxicological effects (Stumm and Morgan, 1981). It has prevented significant amounts of toxic chemicals from being discharged into water bodies. Also, it has several problems such as:

- The large number and variety of toxic substances potentially present in wastewaters;

- Limited knowledge base such as toxicological data for all those compounds identified in wastewater;

- The difficulty in detecting and monitoring these compounds; and

- The technical feasibility to predict their interactive effect.

Use of bioassays as an alternative to chemical-specific approach, has been promoted only in the last few years. The reason for increased use of bioassays is that toxicity is determined readily.Then toxicity becomes a general pollutant category such as biochemical oxygen demand (BOD) or total suspended solids (TSS). Wall and Hanmer (1987) cited the reason for use of toxicity, because general pollutants are already used to regulate water quality. For toxicity, effluent composition is the basis, whereas water quality criteria do not exist for many chemicals.

Hart et al. (1945) using fresh water fishes discussed about the techniques for evaluating effluent toxicity. Upto this date, using fishes for testing effluents is in practice. The very fact, that fathead minnows (Pimephales promelas), a type of fish has been included as one of the three species in USEPA bioassay procedures for toxicity determination of complex effluent implies its importance (Weber, 1989)

As stated earlier, other than fish bioassay procedures, many techniques involving algae,

protozoa, bacteria and invertebrates have been developed and are in use (Bringmann and 
Kuhn, 1980; Cairns et al,, 1976). In recent times, number of bacterial based bioassay techniques have been developed and tested. One of the reasons was the insistence by NPDES in incorporating toxicity assessment within permit renewals. Another reason for development of these bacterial tests are their quick response to the toxicity of wastewater components.

The following are bacterial based bioassays which include evaluation of the following:

- Photoluminescence using Photobacterium phosphoreum (Bulich, 1986.);

- Radio labeled C 14 $^{14}$ uptake using mixed cultures (Larson and Schaeffer, 1982);

- Growth using mixed cultures (Alsop et al., 1980);

- Respiration using enriched nitrifiers (Alleman, 1986);

- Respiration using mixed cultures (Organization of European Community Development, 1987; Klecka and Landi, 1985; and Yoshioka et al., 1986); and

- Growth using Pseudomonas fluorescens (Dutka and Kwan, 1983).

Most of these options, require fairly high capital costs or/and highly trained laboratory personnel. Expenses with respect to regular usage, in comparison are cheaper than a single chemical specific test.Therefore more number of samples could be tested. Some disadvantages are also associated with these tests. For example, reproducibility of a generic mixed culture with uncertain growth and pattern, for the same test at another location is minimal. Similarly, the same could be said of single cultures, too. The reproducibility of single cultures within single cultures is also doubtful. Inspite of such drawbacks, the use of bioassays in water and wastewater analysis is on the rise.

\subsection{Characteristics of petroleum refinery wastewater}

Petroleum refineries have become an inevitable part in the industrial world. Products of petroleum refinery industry are a complex mixture of chemical compounds such as phenol, benzene, napthene and their derivatives. Due to their multivaried products and demand, 
significant differences in the quantity and quality in different wastewater streams within a refinery are encountered. There will also be large differences in parameters such as $\mathrm{pH}$ and temperature between streams. In addition to hydrocarbons, crude oils contain sulfur and nitrogen (each approximately 0.5 to $3 \%$ by mass), certain heavy metals and inorganic salts such as sodium chloride. This type of complexity has brought an increasing concern regarding the carcinogenic or mutagenic potential of specific compounds (and ionic species) and group of compounds, even when present in low (trace) concentrations (Dold, 1989: Konar et al, 1992). It was one of the factors that convinced the USEPA to compile a list of priority pollutants. Rice et al. (1976) reviewed the various works about the uptake and effect of oil and refinery compounds in several species of test animals of a marine system. It was reported that toxicity contribution of refined oils was considered to be higher than crude oils.

The composition of a typical waste stream before and after biological treatment reported by Rebhun and Galil (1987) is provided in Table 1.

\subsection{Microtox}

The Microtox is a bacterial bioassay which is based on monitoring changes in natural light emissions from luminescent bacterium (Photobacterium phosphoreum) upon exposure of a toxic substance. Toxicity and end point is measured as the effective concentration of a test sample that causes a $50 \%$ decrease in light output. Microtox has been described as a simple, inexpensive and rapid bacterial bioassay by its inventor (Bulich et al., 1979) and endorsed by many workers (Curtis et al., 1982; Qureshi et al., 1982; Indorato et al., 1984 ; Blum and Speece. 1991; Arbuckle et al., 1992). It has been found applicable in a wide variety of uses -such as toxicity identification of chemical substances and effluents, monitoring the performance of wastewater treatment plants and hazard assessment of effluents. Also it serves as a prescreening tool in assessing relative toxicity for other 
bioassays such as invertebrates-Daphnia species, vertebrates-rainbow trout, bacterianitrifiers and so on (Vasseur et al., 1984; Wolaver et al., 1993; Alleman et al.,1986).

Table1.1: Examples of concentrations of refinery wastewater pollutants before and after biological treatment (Rebhun and Galil, 1987)

\begin{tabular}{lcccc}
\hline \multirow{2}{*}{ Component } & \multicolumn{2}{c}{ Influent $^{1}$} & \multicolumn{2}{c}{ Effluent $^{1}$} \\
\cline { 2 - 5 } & R \& G & Literature & Literature & R \& G \\
\hline $\mathrm{pH}$ & 8.14 & $6.2-10.6$ & 7.85 & $6.7-7.9$ \\
Total suspended solids & 98 & $15-85$ & 47 & $6-112$ \\
Volatile suspended & 65 & & 26 & \\
solids & & & & \\
COD-total & 625 & $140-3340$ & 230 & $80-300$ \\
COD-soluble & 443 & & 165 & \\
BOD-total & 268 & $7-230$ & 19 & $4-100$ \\
BOD-soluble & 143 & & 7 & \\
Hydrocarbons & 40 & $23-200$ & 4.8 & $0.5-9.0$ \\
Ammonia(as N) & 21 & $0-120$ & 13 & $0-43$ \\
Chlorides & & $19-1080$ & & \\
Sulphides & & $0-38$ & & \\
\hline
\end{tabular}

1. concentrations in $\mathrm{mg} / \mathrm{l}$ except for $\mathrm{pH}$

2. R\&G-Rebhun and Galil

3. COD-Chemical oxygen demand 


\subsection{Surrogate parameters}

There are some questions, in spite of the increasing use of bioassays and its wide spread applicability. That is, an aquatic bioassay does not measure the "strength" of those pollutants. Rather it is found to be for the most part subjective. With recent emphasis on priority pollutants, and to bioassay, the inclination towards conventional parameters such as BOD, COD and phenols to determine treatment standards were questioned. This was reflected by Huber et al. (1979), as a significant correlation between effluent toxicity with parameters such as ammonia, oil and BOD could not be obtained for coastal refinery effluent toxicity data. It was attributed to the complex compounds seen in refinery effluents and the numerous interactions between them. Still, Maynard (1989) indicated that surrogate parameters could be identified as, and used to assess the changes in the degree of effluent quality. A major difficulty is in developing a large database, in the event surrogate parameters are used in effluent quality determination. Also, establishing statistical correlations between surrogate parameters and level of specific contaminant or bioassay does not work with all effluents. This was realized in studies conducted on refinery effluents, by the Petroleum Association for Conservation of the Canadian Environment (PACE)(1985a). Later, Bảckman and Firth (1990) established a significant statistical relationship between a bioassay- using rainbow trout and an effluent parameterlow molecular weight adsorbable organic halogens (AOX), in paper and pulp mill effluent. 


\subsection{Objectives of the study.}

The objectives of the study were as follows:

1. to evaluate the toxicity of refinery effluent using Microtox as bioassay;

2. to compare the results of Microtox with wastewater parameters such as chemical oxygen demand (COD), $\mathrm{pH}$, total dissolved solids(TDS), total suspended solids (TSS), total petroleum hydrocarbons (TPH) and ammonia-nitrogen $\left(\mathrm{NH}_{3}{ }^{+} \mathrm{N}\right)$;

3. to establish a relationship between these wastewater characteristics and toxicity values $\left(\mathrm{IC}_{50}\right)$ statistically; and

4. to examine the effectiveness of the API separator and stabilization pond used in treatment of refinery wastewater in a local refinery in toxicity reduction.

\subsection{Scope of the study}

The scope of the study included a review of literature on toxicity studies of refinery effluents, through various biclogical assays including the usefulness of Microtox as a screening tool in assessing toxicity of various types of wastewaters. Laboratory studies were conducted to evaluate the toxicity (Microtox assay) of refinery effluent collected at three sampling points- before and after API separator and after stabilization pond, from Consumers' COOP Refineries Ltd, Regina. Simultaneously the treated effluents were analyzed for wastewater parameters, identified for this study. Both results were analyzed, statistically. 


\section{Chapter Two}

\section{REVIEW OF LITERATURE}

\subsection{General}

Toxicity identification has an advantage over specific chemical analysis of complex effluents. It can indicate the need for additional characterization of effluent. Depending on the purpose and type of usage, toxicity test results can be combined with chemical contaminant analyses. One of those is establishing a statistical correlation between toxicity and chemical parameters of treated and untreated effluents. It has been found to be a reasonable indicator, in assessing the strength of other contaminants. These relationships are found to be quite useful, in the case of industrial effluents such as petroleum refinery effluents. This tendency is likely to be observed in other type of effluents, too. Among so many bioassays, Microtox toxicity system has been used in several identification tests. Its simplicity and reproducibility are the major factors. 


\subsection{Acute toxicity testing of refinery effluents}

Monitoring of effluents is necessary to protect aquatic life and quality of water. Though a difference in composition exists between treated domestic and industrial wastewaters, the impact of them in terms of lethality on aquatic life is not much different. Because, other than the presence of complex chemicals, a treated municipal effluent may contain a disinfectant such as chlorine, which is toxic to aquatic organisms. Presence of ammonia is likely to raise a concern. A not so fully treated effluent such as a partially nitrified effluent that contains sufficient concentrations of ammmonia may be toxic to aquatic life. Sometimes industrial wastes discharged to municipal treatment system could add toxic chemicals in sufficient quantities thereby increasing the lethality of the domestic effluent. Impact of these two effluents on organisms could be acute or chronic and both will be discussed here.

Impact of refinery effluents on aquatic organisms has been reported by Clemens et al.(1953). Static toxicity tests with five different vertebrate species were conducted with a refinery effluent that had been treated with only mechanical separators. Lethal concentration causing 50 percent inhibition $\left(\mathrm{LC}_{50}\right)$ values ranged between $17-33 \%$ of effluents. Armant et al. (1980) performed acute toxicity tests using an in-vitro enzyme, 6phosphate dehydrogenase(G6PDH). After an incubation period of 30 minutes in test solution the enzyme activity was monitored spectrometrically. At the same time static animal bioassays using Daphnia and gold fish (Carassius auratus) were performed on a refinery effluent. Effluent was collected before and after secondary treatment. Untreated effluent was found to be quite toxic as observed from $\mathrm{LC}_{50}$ values, to Daphnia. They were 3.57 and $0.37 \%$ of effluent at 24 and 48 hours respectively. It exhibited toxicity to goldfish at concentrations of 18 percent and above, whereas the activity of enzyme was inhibited by $18 \%$. Treated effluent was not found to be toxic to Daphnia and gold fish. 
Enzyme activity was reduced by 12 percent at this stage. As expected, the complete arbitrary reference mixture (ARM) was found to inhibit enzyme activity by $86.1 \%$. Likewise, some compounds of ARM such as sulfide, oil and kaolinite exhibited equal amount of toxicity to G6PDH enzyme. In fact, kaolinite, a particulate inorganic constituent of ARM inhibited more of enzyme activity, say by 92.4 percent, than complete ARM or any individual components.It indicated that the enzyme would have adsorbed kaolinite from ARM, whereas not TSS of refinery effluent. This discrepancy was attributed to the chemistry of these two components. TSS of refinery effluent and kaolinite were identified to be principally organic and inorganic particulate substances. Therefore, it was a surprise when the particulate complex-total suspended solids (TSS) by its presence or absence in refinery effluent did not alter inhibition rate by a great extent. Another surprising factor was the reactivity of phenol. Individually or deleted from ARM, phenol exhibited no appreciable amount of toxicity to G6PDH enzyme, when tested. Presence of chromium and ammonium were found to negate the effect of kaolinite, as greatest reduction in inhibition was observed, when the three constituted a group. Influence of ammonium over certain substances inhibitory effect was quite complex. It reduced the lethality of kaolinite while slightly modified the inhibition of the same substrate when chromium was present. Reaction patterns observed from this study led to the conclusion that there are three types of substances in ARM. They are inhibitors like -kaolinite, inert material-phenol and modifiers of inhibition-ammonia and chromium. Also, the complex interactions that occurred between ARM components were not different from the refinery effluent toxicity results, observed earlier in this study.

Sprague et al. (1978) conducted a series of 4-day screening bioassay tests of flow through type with a refinery effluent. Effluent chemical measurements were within or almost exactly at the regulatory limits (Environment Canada, 1974). Species used were rainbow trout (Salmo gairdneri). An average highest temperature of $15.3^{\circ} \mathrm{C}$ and a pH of 7.4 were maintained at test conditions. Average dissolved oxygen concentration (DO) 
concentration varied from control to full strength at about 9.9 to $7.7 \mathrm{mg} / \mathrm{l}$. At 100 percent concentration of the effluent, mortalities in most of the tests were low or absent. It was attributed to aggression of fish and not to effluent. Distribution of aeaths also indicated that the strength of effluent plays a vital role in aggressivity of fish. It was observed from the death distribution from control to full- strength as shown by $5 / 10$ to $1_{i}^{\prime} 10$.

Pessah et al, (1973) conducted acute toxicity tests on rainbow trout and fathead minnows, by exposing them to multiple effluent concentrations. Static and flow through $(90 \%$ solution replacement within 15 hours) conditions were maintained during the tests. Also, acute bioassays were performed with formulated "effluent". Effluents collected after secondary treatment from six refineries were used as samples. Formulated effluent was prepared using the concentrations of ammonia, oils, phenols and sulphides as recommended by Environmental Protection Service (EPS) and attainable by best practicable treatment (BPT) in a refinery. The effluents were used in tests, without any $\mathrm{pH}$ adjustment. Of the six effluents, four (\#1, 2,3 and 4) exhibited lethality to the species. $\mathrm{LC}_{50}$ of the first three samples were $21 \%, 40 \%$ and between 75 and $100 \%$ effluent concentrations. At 100\% effluent concentration \# 4 effluent produced a partial mortaiity. Remaining two effluents did not produce mortality at any concentration. Ammonia (160 $\mathrm{mg} /$ l) was identified to be the contributor of toxicity in \#1 refinery effluent. Similarly phenols $(3.3 \mathrm{mg} / \mathrm{l})$ were found to be the major ccntributor to lethality in refinery $\# 2$ effluent. On many occasions all toxic contributors in an effluent were not identified. This was demonstrated by the results of refinery effluent \#4. Although the individual constituent levels of this effluent were well below effluents that exhibited acute toxicity and produced no mortality, contributors to the mortality in \#4 effluent were not clearly identified. Therefore it was presumed that the caustive agent would be an unmeasured constituent or the synergism among various chemicals. Degree of waste treatment plays a major role in toxic characteristics of wastewater. Among the two effluents, which did not 
cause mortality, refinery \#6 had the highest degree of purificatiol. Refinery effluents \#2 and 3 had inadequate secondary treatment and it was observed in their lethality to trout fish. Despite the presence of secondary treatment, \#1 effluent exhibited greatest lethality. This was attributed to the inadequate functioning of sour water stripper and subsequent increase in ammonia concentration. Test conditions were also found to influence the mortality rate of species. Mortality rate of rainbow trout in $100 \%$ effluent of refinery $\# 4$ at flow through was consistently higher than static conditions. Because, concentration of toxic elements would deplete due to absorption by fish and side of the vessels (glass, plastic or Type 316 stainless steel) and by biodegradation or volatilization. This is quite conimon in static bioassays. Among the test species, rainbow trout was found to be more sensitive than fathead minnows.

Matthews and Myers (1976) conducted a series of studies to compare the effectiveness of various treatment schemes for reducing effluent toxicities. Test organisms used were redear sunfish (Lepomis microphus) of length 20-50 millimeters. A two-phase study was conducted. In the first phase about 50 samples were collected from 17 refineries. To prevent evaporation of many volatile constituents in refinery effluent, samples were not aerated. Further, the test period was restricted to 24 hours. Samples were tested at dilutions of $1.0,1.8,3.2,5.6$ and $10 \%$. Percentage volume of wastewater in respective samples was used to calculate $\mathrm{TL}_{50}$ the inhibitory values. Of all the samples tested, only 20 of them exhibited toxicity. TL 50 value of those sampies varied from $0.04-13.5 \%$. More than one sample of three refineries were found to be more toxic than indicated by results of chemical analysis. It was suggested that toxic nature of the samples could have been contributed by toxic hydrocarbon compounds. In first phase, four different symptoms such as erratic swimming, hyperactivity and slow circular swimming were observed in the dying and distressed fish. In phase II, about 12 samples from 5 refineries were tested for toxicity. Samples collected after American Petroleum Institute (API) separator exhibited 
toxicity. The 24 hour $\mathrm{TL}_{50}$ of these samples varied from $4-50 \%$. All effluent samples collected after activated sludge process (ASP) system exhibited a reduction in toxicity levels. Fishes did not show any symptoms such as stress or mortality when tested in final clarifier effluents. Among the final clarifier effluents, one effluent exhibited a toxicity of $20 \%$. This was identified partly to ammonia and partly to some unidentified biodegradable toxicants. Fishes tested in the remaining effluent samples which were at 100 percent concentration, did not show any symptoms such as stress or mortality.

Different species of same vertebrate would establish differences in resistance or susceptibility to a toxic effluent. The difference was found to depend mostly, on conditions of fish, to be used as a bioassay. Douglas et al (1963) conducted fish bioassay studies to identify the existence of such a relationship. Sixteen species of fish were used as test specimens. Effluent was collected from before and after a holding pond, confined within the refinery. To establish the test concentrations of effluent for bioassays, an exploratory test with wide dilutions were made.Sampling pattern was designed suitably to compare long-term effects of more toxic wastes with effects of treated effluents of low toxicity. A total volume of 10 litres of diluted refinery effluent was used for each test. To avoid any fish death due to respiration, each container was applied with sufficient quantity of oxygen. Results were recorded at time intervals of lhour, 6, 12, 24, 48 and 96 hours. $\mathrm{TL}_{50} \mathrm{~m}$ values were determined from graphs plotted between strength of effluents and percentages of survival at corresponding time intervals. According to literature, in this study the 24-hour results were considered to be most applicable and significant. Statistical populations were developed through Duncan new multiple range test. These four populations contain species of different resistivity, to the refinery effluent. Statistical populations of both $24 \mathrm{~h}$ TL $50 \mathrm{~m}$ and $96 \mathrm{~h} \mathrm{TL} 50 \mathrm{~m}$ values were found to be almost equal. Authors reported that difference between most resistant and least resistant species to toxicity of refinery effluent was very close. 
Acute toxicity tests of $96-\mathrm{h}$ duration to evaluate the effects of diesel oil, crude oil and refinery effluent were conducted by Das et al. (1988). Organisms used were a cladoceranD. magna; a mollusc-Viviparus bengalensis; a fish-Tilapia mossambica and a chironomid larvae. Fish was exposed to crude oil and refinery effluent. Lethal concentrations $\mathrm{LC}_{5}$, $\mathrm{LC}_{50}$ and $\mathrm{LC}_{95}$ at $95 \%$ confidence limits were calculated statistically. Abnormalities such as uncoordinated movements were observed in Daphnia and insect larvae after initial exposure of diesel oil and oil refinery effluent. In the case of mollusc, huge secretion of mucus and retraction of mantle into shell was observed. Apart from erratic movements, suffocation followed by lethargic movements were noted in fish. A comparison of lethal concentration $\left(\mathrm{LC}_{\mathrm{X}}\right)$ values indicated that diesel oil was more toxic than refinery effluent to the species. For fish, crude oil was found to be more toxic than oil refinery effluent. Among the three species, that were exposed to diesel oil Daphnia was found to be more sensitive. The $\mathrm{LC}_{50}$ values of Daphnia, mollusc and chironomid larvae were 20.0, 254,0 and $346.0 \mathrm{mg} / 1$ respectively. Similarly $\mathrm{LC}_{50}$ values for oil refinery effluent indicated that the zooplankton Daphnia was most sensitive amongst tested species. This higher sensitivity was reasoned to the soft, uncovered body and lack of detoxifying enzyme system of Daphnia.

\subsection{Chronic toxicity testing of refinery effluents}

Graham et al.(1968) conducted chronic toxicity studies on fish to investigate the effect of refinery effluents, for extended periods. Test animals used were the species fathead minnows (Pimephales promelas). From four refineries, total effluerits were collected and used as samples. Among them, effluents $\mathrm{A}$ and $\mathrm{B}$ exhibited high toxicity whereas, $\mathrm{C}$ and D were relatively low in toxicity. An exposure period of 32 days was selected for this chronic toxicity tests. Results indicated that lethality of high toxicity effluents at sub acute concentrations did not cause a great harm to fish life, as there were not any differences, in behaviour or appearance between the control and test specimens. Survival rate after 16 
and 32 day periods for refinery effluents A and B at effluent concentrations of $20 \%$ and $9 \%$ varied between 65 and $100 \%$. In low toxicity refinery effluents $\mathrm{C}$ and $\mathrm{D}$, a total of 11 experiments were conducted. These effluents contained planktonic organisms and green algae. Effluents were tested at concentrations of $40,60,80$ and 100 percent. Tests included both (96h) and continuos renewal (upto 32 days). In the long term tests, different responses in fish were observed. In all 100 percent concentration solutions and other concentrations fish distress periods of 20 to $72 \mathrm{~h}$ and 12 to $24 \mathrm{~h}$ were observed. Symptoms such as loss of appetite and erratic swimming were obseved. Fish death in 100 percent effluent samples started occuring between the 9 to 25 th day. Mortality in routine tests varied between 0 to $10 \%$ whereas $25-100 \%$ mortality was observed in continuos tests. At the end of 32 nd day in 100 percent concentration, the survival varied between 10 to $100 \%$. This 100 percent survival was observed in an effluent collected where the catalytic crackers were not in operation. Storage effect on the toxicity strength of effluents was observed in some effluents. An appreciable change of about 20 percent (from 60 to $80 \%$ ) was observed in experiment 10 during 16 day storage. Most of the low toxicity effluent samples were collected after stabilization period. One of the reasons identified for this toxic effect was the presence of components like cyanide and metal salts. It was observed that a tretaed refinery effluent with no acute toxicity could produce chronic toxicity due to prolonged exposure. Also,it was suggested that a dilution ratio of 1:4 was necessary to reduce chronic toxicity concentration of these effluents.

Buikema et al. (1976) conducted toxicity tests on Daphnia species to assess their suitability. Initially the species were tested in an arbitrary reference mixture (ARM) made with six specific chemicals, usual constituents of a refinery effluent. Both Daphnia pulex and Daphnia magna were used as specimens. Further the species were tested with six refinery effluents, too. Results with ARM, indicated that the presence or absence of oil as a constituent did not affect the reproducibility of tests, although oil itself has been found 
to be toxic to the crustacean. Mean $\mathrm{LC}_{50}$ values at 8, 24, 48 and 96 hours for ARM were $0.18,0.11,0.07$ and 0.03 respectively. Likewise, the $\mathrm{LC}_{50}$ values at $8,24,48$ and 96 hours for ARM without oil were 3.84, 1.76, 0.96 and 0.42 respectively. Tests performed at refineries with refinery effluents, proved to be reproducible, though variations were expected in refinery processes among refineries. For each refinery effluent, 5 to 8 tests were conducted. Refinery effluent \#B proved to be non toxic at all intervals. $\mathrm{LC}_{50}$ values for the refinery effluents in particular at 48 hour intervals, ranged from non toxic to $102 \%$ of effluent.

Sprague et al. (1978) in an advanced tier testing, investigated the sub lethal effects of refinery effluents. The sub lethal effects selected were effects on growth, survival and reproduction. Specimens used were, rainbow trout, flagfish and a crustacean Daphria pulex. Effluent was collected after complete chemical and biological treatment. Specimens were tested at different concentrations of effluent. Threshold concentration for effect on growth, in the case of rainbow trout was found to be $9.4 \%$. Irrespective of the feeding rate an effluent concentration of $30 \%$ was found to affect severely the growth of rainbow trout. Other effects at this concentration include erosion of caudal fins, difficulty in maintaining stability against a modest current and no response upon the appearance of fish net. Likewise, threshold concentration in the case of tropical flagfish with respect to survival, growth and reproduction was about $9.1 \%$. At this concentration, some notable effects were observed on final size of males of the starting generation. "Coughing" and respiratory rate of trout were found to increase with rise in concentrations of effluent. Relative locomotor activities were found to increased with 10 percent effluent concentration, whereas such activities decreased at 30 percent effluent concentration. The activities include number of entries into tank, spatial pattern of entries and time spent in various parts of the tank. Also, higher effluent concentration was found to affect only the number of entries. The water flea Daphnia-pulex was found to be more sensitive, 
approximately 2.5 times than rainbow trout, observed from the $48-\mathrm{h} \mathrm{LC}_{50}$ values. About $5 \%$ of Daphnia pulex failed to reproduce at $0.52 \%$ concentration, which was found to be the "safe" level.

Nikunen (1985) conducted toxicity tests to identify the impact of effluents from a petrochemical industry into the receiving waters. The main plant is a petroleum refinery in this industrial complex. Three different species -fish (Salmo gairdneri), cladoceran (D. magna) and bacteria (Salmonella typhimurium), collected from different tropical places were used. In acute toxicity tests involving D. magna, none of the tested wastewater samples showed any detectable acute lethal effects. In long-term tests, both fish and $D$. magna responded with some significant changes. At an effective concentration causing $\mathrm{EC}_{50}$ of $3 \%$, a significant change in reproduction rate was observed. With some individuals, even a concentration of $30 \%$ did not hinder the reproductive ability. Therefore a large deviation in sensitivity to the effluent by this species was observed. Of the various parameters chosen to indicate metabolic changes in fish, the detoxication enzyme system proved to be the most sensitive indicator of combined effluent's toxicity. Increase in the activity of enzymes coupled with protein synthesis in liver stimulation were the changes caused, due to effluent exposure. The effluent also evoked a negative response in Ames test, both with and without metabolic activation.

Adversity of petroleum effluent reaches higher proportions, if it combines with other pollutants. Konar et al. (1992) found that petroleum effluents at sub lethal concentrations with non-ionic detergent pollutants produced severe effects on aquatic life. They conducted 7-day chronic tests on fish Tilapia mossambica, using a constant level of nonionic detergent concentration $(11.88 \mathrm{mg} / \mathrm{l})$. Different levels of petroleum effluent such as $0.87,1.75,3.50$ and $7.0 \%$ were used. The endpoints observed include behavioral patterns, growth rate, total yield, fecundity, maturity index, condition factor and gastrosomatic index. From the results, it was observed that the severity was more due to the mutual 
presence of each pollutant. At higher concentrations an increase in lethargic activity and reduced vitality were observed. Reduction in growth rate was attributed to the loss of olfactory power. The presence of both pollutants resulted in a reduction in maturity index and fecundity of fish.Similarly, a damage to the digester system resulted in an increase in gastronomic index (GSI). Reduction in fecundity was related to the tendency of fish to accumulate hydrocarbons. This supported the earlier findings that refinery effluent alone, could not change the maturity index of male fish- T. mossambica.

Apart from the adverse effects, the refinery effluents also exert subtle, still deleterious long-term effects on aquatic system. Sherry et al. (1994) conducted a battery of tests, which included acute, chronic and subchronic tests. Test specimens were collected from bacterial, algal, plant, cladoceran and fish communities. Effluent samples collected from two refineries namely 'A' and 'B' were used in these tests. Acu'e toxicity tests with cladoceran (Daphnia) and fish (Rainbow trout) indicated that the degree of effluent treatment provided was reasonably well in these refineries. Therefore, chronic and sublethal toxicity tests were conducted on fish (Pimephales promelas), cladoceran (Ceriodaphnia dubia), algae (Selenastrum capricormutum), plant (Lemna gibba), Laciuca sativa seeds and the nematode (Panagrellus redivivus). Tests were conducted according to standard procedures. Responses monitored in the specimens were mostly survival, growth and germination. For fish, cladoceran, algae and plant specimens, the refinery effluent 'B' proved to be non-toxic. The same was observed with sample \#1 of refinery 'A' except for affecting growth of fathead minnow larvae (No observed effective concentration, NOEC 25\%) and survival of Ceriodaphnia. Sample \#2 of refinery effluent 'A' exhibited a slight lethality to nematode. It also inhibited the growth of selenastrum (inhibition concentration-IC 50 of $59.9 \%$ ) and lemna $\left(\mathrm{IC}_{25}\right.$ of $\left.73.3 \%\right)$. In some of the toxicity tests, effluent concentrated upto $25 \mathrm{x}$ were used. Impact was more, as observed from the response of nematode. 


\subsection{Microtox as an assay in industrial wastewaters}

Use of Microtox as an assay for environmental samples has been well recorded (Bulich, 1979; DeZwart et al, 1983). Either individually or along with other species Microtox has been increasingly used in assessing the toxic nature of municipal and industrial wastewaters (Qureshi et al.,1982; Backman et al., 1990). This increased use was due to the sensitivity of Microtox and its closely associated results with other bioassays (Strosher, 1984).

Several complex effluent samples including two samples from oil refineries were tested for toxicity by Qureshi et al. (1982). The study was undertaken to compare the performance of Microtox test in terms of sensitivity with that of a bacterium (Spirillum volutans), a crustacean (Daphnia magna) and rainbow trout (Salmo gairdnerri). Microtox 100\% effluent procedure was used to test the effluent. Additionally, a $50 \%$ effluent was also tested in the same test. From results, it was noticed that greatest sensitivity among bioassays was exhibited by Microtox to the refinery effluents. For one refinery effluent $\mathrm{OR}, \mathrm{A} 1$, the $\mathrm{IC}_{50}$ as observed from microtox test was $6.5 \%$ vol./vol. Fish and Daphnid bioassays registered a 96 and 48 hour $\mathrm{LC}_{50}$ of $71 \%$ and $78 \%$ for the same effluent. Microtox recorded a $\mathrm{IC}_{50}$ of $<50$, for another refinery effluent, whereas the effluent did not create any impact to fish. Microtox exuded a toxic response, to all effluents, that were toxic to other bioassays, used in this test.

Ankley et al. (1990) used sucrose as an osmotic adjustor instead of $\mathrm{NaCl}$, in Microtox tests to identify toxicity of 44 effluent samples. These samples include twelve collected from oil treatment facilities. Two standard test species fathead minnow (Pimephales promelas) and cladoceran (Ceriodaphnia dubia), other than Microtox were used. Survival of Ceriodapnhia was recorded at 24 and 48 hours and fat head minnow at $24,48,72$ and 
96 hours. In Microtox test, the effluents were tested at concentrations of 7.5, 15, 30 and $60 \%$ along with control. Of the twelve oil treatment samples tested, three of them exhibited toxicity to Microtox tested in $\mathrm{NaCl}$. $\mathrm{EC}_{20}$ values were $36.6,13.1$ and $11.2 \%$ respectively. Only two of these samples, mentioned earlier, were sensitive to Microtox tested in sucrose. Of these three samples that evoked response from fathead minnow, two were toxic to Microtox, tested in both osmotic adjustors. The cladoceran C.Dubia, responded to four of the twelve tested samples. Generally, Microtox was found to be the most sensitive, tested among the three bioassays. A different pattern was observed in results tested with sucrose, than those from $\mathrm{NaCl}$. Still, it was suggested that sucrose should be used only in association with $\mathrm{NaCl}$.

\subsection{Comparison of Microtox and other bioassays}

Hansen (1989) conducted toxicity identification evaluation (TIE) studies at a petroleum refinery in Martinez, California. One of the objectives was to select an effective monitoring tool, for routine screening of the wastewater. Initial tests included feasibility analysis of the conventional parameters COD, BOD and TOC as surrogate indicators of fish toxicity. Statistical analysis yielded low correlation coefficient values between wastewater parameters and fish bioassay such as -0.04 to -0.27 , suggesting elimination of these parameters.

Later, simultaneous bioassays with Microtox and a fish species (threespine stickleback) were performed on a number of waste stream samples. The test results indicated that Microtox could be an effective screening tool, not an exact predictor of fish toxicity. With Microtox, the effluent was monitored for a five month period. Statistical analysis yielded a mean toxicity of $29.0 \%$ effluent $\left(20 \mathrm{~min}\right.$. $\left.\mathrm{EC}_{50}\right)$. During the monitoring period, a maximum and minimum $\mathrm{LC}_{50}$ value of 100 and $1.1 \%$ of effluent were registered. Using an 
adjustment factor, the three spine stickle back(Gasterosteus Aculeatus) $96 \mathrm{~h} \mathrm{LC}_{50}$ results were expressed in terms of microtox $20 \mathrm{~min}$. $\mathrm{EC}_{50}$. It was observed to be $59 \%$ of effluent, with a standard deviation of $30 \%$ effluent.

Backman et al. (1990) evaluated the use of microtox test to screen untreated and treated pulp and paper mill waste wasters. Bioassays were conducted with Ceriodaphnia, rainbow trout and Microtox. With Ceriodaphnia, a 7 day chronic bioassay for eight samples was conducted. At two occasions, on seventeen samples, acute tests using rainbow trout (96h) and Microtox(15 min.) were conducted. Comparisons of acute and chronic toxicity values with Microtox $\mathrm{EC}_{50}$ values were made, from the results. Microtox proved to be a good screen for both bioassays, with correlation coefficients of $r=0.91$ and 0.94 respectively. Among wastewater parameters, the low molecular weight AOX $(<1000$ mol.wt) and $\mathrm{BOD}_{5}$ were found to be best predictors of rainbow trout toxicity. The $\mathrm{r}$ values were 0.94 and 0.8 respectively. An important thing here to be noted was, the values of AOX, related to both treated and untreated waters. In spite of a noteworthy linear relationship between Microtox and Ceriodaphnia bioassay tests, the $\mathrm{EC}_{50}$ values were larger than those of chronic toxicity threshold values (ChV). Among the mill wastewater parameters, except for total $\mathrm{BOD}_{5}$ with a correlation coefficient of 0.73 , none of them could be identified as a good predictor of Ceriodaphnia response. For all the five samples of final effluent, Ceriodaphnia was more sensitive than Microtox. Generally, it was observed, that a linear relationship could be established to predict a bioassay response using Microtox. 


\section{Chapter Three}

\section{Materials and Methods}

\subsection{Wastewater}

Wastewater used in this study was collected at three different locations in the wastewater treatment scheme of Consumers' Co-operative Refinery Ltd, Regina. These locations are (a) influent to American Petroleum Institute (API) separator, (b) effluent from American Petroleum Institute (API) separator, and (c) final effluent discharged to Regina sewer system. The plant wastewater includes the wastewater from processes and occassional storm water flow. The treatment scheme is a combination of pretreatment of oily wastewaters and secondary wastewater treatment. A schematic representation of the treatment processes is shown in Figure 3.1

All wastewater samples used for this study were grab samples collected once a week, (every thursday) and stored in amber glass containers to avert photodegradation of phenols and certain hydrocarbons and ammonia. To analyse the toxicity of wastewater, samples were collected for 11 weeks. All samples except for the sample collected on week \#5, were used in surrogate analysis. Samples are designated as 1(a) or 2(b) or 3(c): the number indicates the week of collection and the alphabet indicates the collection point. 
For example, sample 1(a) indicates that the sample was collected on the first week at the influent to API separator. The collected samples were acidified immediately with concentrated sulfuric acid. For every liter of sample, $2 \mathrm{ml}$ concentrated $\mathrm{H}_{2} \mathrm{SO}_{4}$ was added to adjust the $\mathrm{pH}$ of samples to below 2 .

Acidification of the samples was believed to prevent biological and chemical oxidation of certain hydrocarbons. The acidified samples were stored in a cold storage unit at $4^{\circ} \mathrm{C}$, before conducting the analysis and toxicity tests.

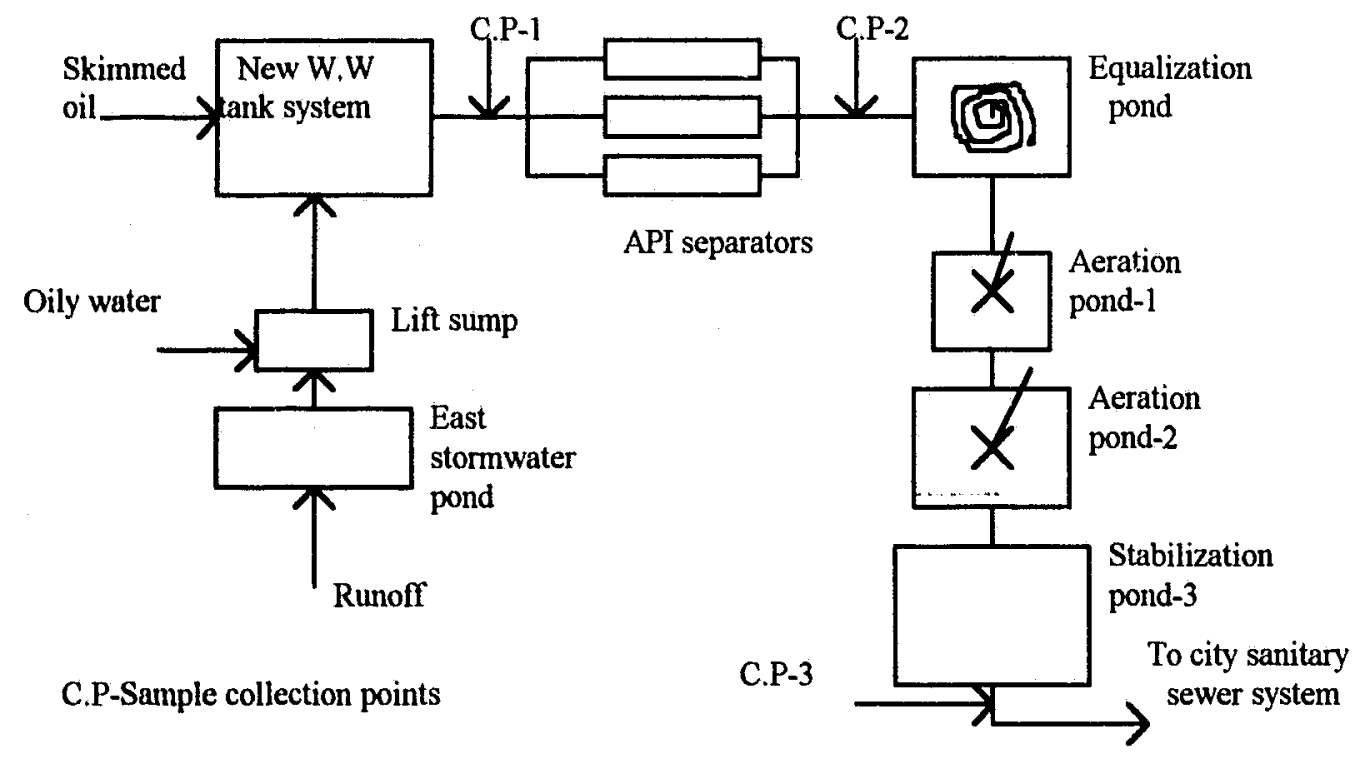

Figure:3.1 Wastewater collection and treatment system in Consumers'COOP refinery Ltd, Regina.

\subsection{Microtox}

The Microtox system used in this study included an incubator, a freeze dried reagent (Photobacterium phosphoreum), Microtox osmotic adjusting solution (MOAS) and diluent and reconstitution sollutions supplied by the Microtox Inc,Carlsbad, California, U.S.A. MOAS is a specially prepared $22 \%$ solution of sodium chloride $(\mathrm{NaCl})$ toxicity- 
free used to provide osmotic protection to the Microtox reagent .The diluent is a specially prepared $2 \% \mathrm{NaCl}$ solution, toxicity-free used for diluting the sample and reagent. Reconstituent solution is a specially prepared toxicity-free distilled water used for reconstituting the reagents. The reagent was stored in a freezer at $-20^{\circ} \mathrm{C}$, while the three solutions were stored in a refrigerator $\left(40^{\circ} \mathrm{F}\right)$.

\subsection{Toxicity studies using Microtox.}

Toxicity studies were conducted using the Microtox analyzer, manufactured by Microbics Inc., Carlsbad, California, USA. Experiments were run according to standard procedures, in this case-duplicate basic test as per the Microbics operating manual (1992). The procedure was found to give more confidence in test results. Therefore it was used to run tests.Output of the experiment was obtained through a printer connected to the analyzercomputer. A photograph and schematic diagram of the experimental set-up is shown in Figure3.2. At the start of experiments the three effluent samples were screened by the condensed $2 \%$ screen test according to the Microbics operating manual. This helps not only to identify the possible toxic range of samples, but also helps to know the requirement of primary dilution of the samples. Except for the stabilization pond effluent sample, the other two samples were prepared by primary dilution(dilution factor 1:10) and adjusted to an initial concentration of $4.5 \%$. The stabilization pond effluent sample was tested at an initial concentration of $45 \%$. All the three samples were concentrated using a centrifuge.This was done to prevent interference of the suspended particles during the bioassay. They are concentrated at a speed of $300 \mathrm{rpm}$ for 3 to 5 minutes. The samples thus obtained were tested using the duplicate basic test procedure. This procedure involve five stages that include (i) analyzer preaparation, (ii) sample preparation, (iii) reagent preparation, (iv) computer preparation and (v) test protocol. In the first stage, cuvettes are placed in rows A, B \& C and reagent well. About $1000 \mu \mathrm{l}$ reconstituition solution is added 

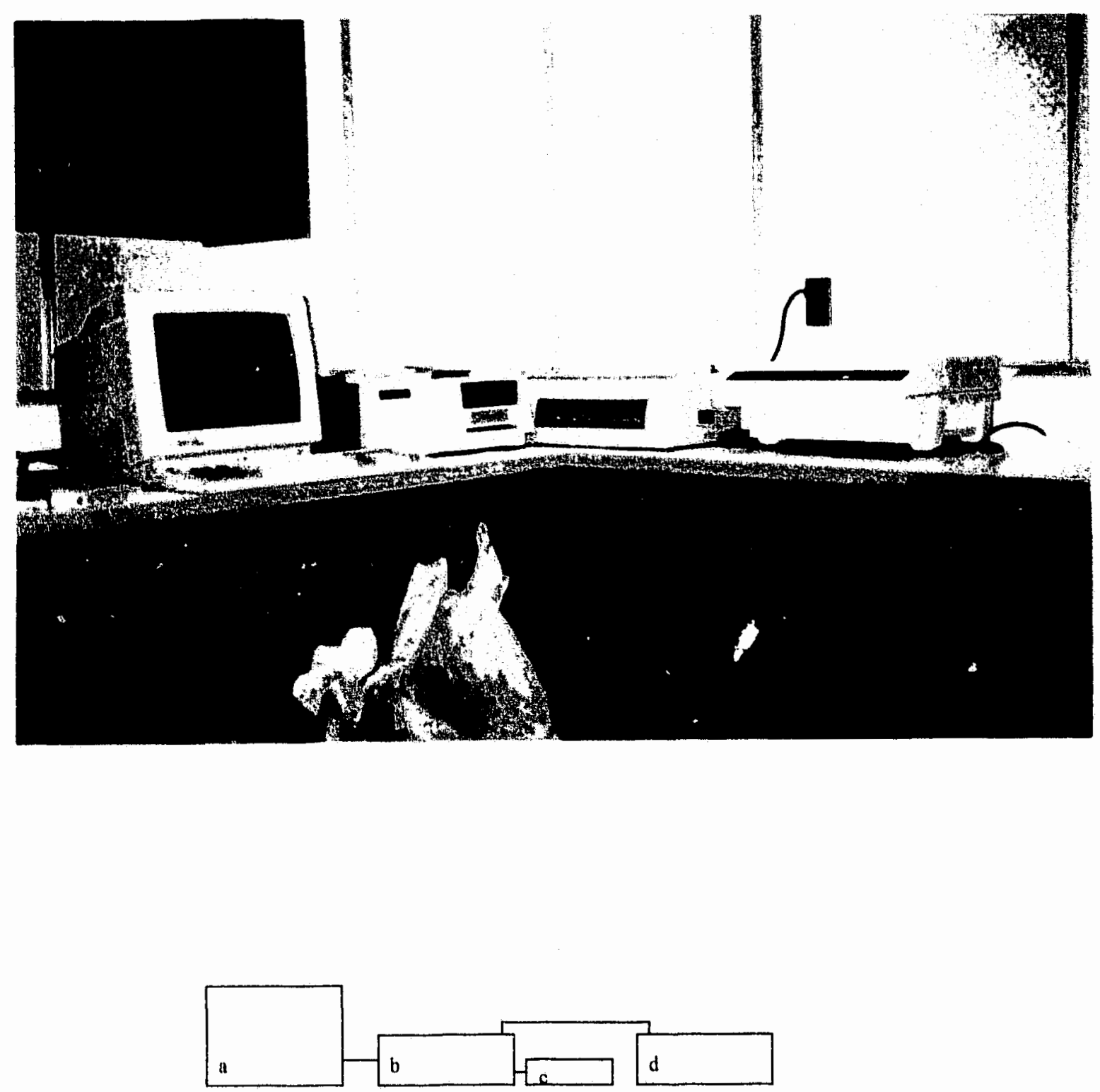
a Monitor
c Printer
b Central processing unit d Microtox analyzer

Figure 3.2 A photograph and schematic diagram of the experimental setup of present study 
to cuvette in reagent well. A volume of $1500 \mu \mathrm{l}$ and $500 \mu \mathrm{l}$ diluent are added to cuvettes A1 to $\mathrm{A} 4$ and $\mathrm{B} \& \mathrm{C}$ rows respectively. Sample preparation stage involve preparaztion of 1:2 serial dilutions. Samples prepared by primary dilution or not are osmotically adjusted using the MOAS to a volume of $2750 \mu \mathrm{l}$. Third stage include the reconstituition of freeze dried reagent with reconstituition solution and transfer of $10 \mu l$ into test cuvettes. After addition, they are allowed to equilibrate for 15 minutes. Installation of basic test protocc in computer is the fourth stage. The final stage involve measuring light levels of Microtox reagent before and after introduction of test samples. At first, initial light output $\left(\mathrm{I}_{\mathrm{O}}\right)$ was recorded on the computer screen, before transferring test samples to test cuvettes. Afier the introduction of samples to these cuvettes, light output was measured at 1,15 and 30 minutes. If the initial light output readings of any test cuvettes was not between 80 and 100 , then that test was aborted. After the completion of tests, Microtox calculations menu from master menu was used to reduce the data and obtain the effective concentration $\mathrm{IC}_{50}$.

Results were presented in a graphical form by plotting log Concen ration vs log Gamma. Gamma is the ratio of light loss by the reagent light remaining after exposure of a toxicant. The IC is calculated in the following manner.

$\mathbf{R}_{\mathrm{t}}=\mathrm{I}_{\mathrm{tc}} / \mathrm{I}_{\mathrm{OC}}$

$\mathbf{R}_{\mathrm{t}}=$ Correction factor (blank ratio or control ratio )

$\mathrm{I}_{\mathrm{tc}}=$ Light level(1) at incubation time $(\mathrm{t})$ of the control $(\mathrm{c})$

$\mathrm{I}_{\mathrm{oc}}=$ Light level( 1 ) at incubation zero time (0) of the control (c)

Gamma $(\Gamma)$ for each sample concentration.

$\Gamma_{\mathrm{t}}=\left[\left(\mathrm{R}_{\mathrm{t}} \times \mathrm{I}_{\mathrm{o}}\right) /\left(\mathrm{I}_{\mathrm{t}}\right)\right]-1$

$\mathrm{I}_{\mathrm{O}}=$ Initial light reading

$\mathbf{I}_{\mathrm{t}}=$ Final light reading

The percent light loss $\% \Delta$ is calculated with Gamma $(\Gamma)$ :

$$
\% \Delta=\Gamma /(1+\Gamma)
$$


The concentration where Gamma is ' 1 ' and the percent light loss is $50 \%$ is the $\mathrm{IC}_{50}$.

\subsection{Analytical Procedure.}

The wastewater analysis involved the determination of $\mathrm{pH}$, suspended solids (SS), total dissolved Solids (TDS), chemical oxygen demand (COD), ammonia nitrogen $\left(\mathrm{NH}_{3}{ }^{+} \mathrm{N}\right)$ and total petroleum hydrocarbons (TPH). The $\mathrm{pH}$ of the wastewater samples was determined using a Fisher Accumet $\mathrm{pH}$ meter (Model 620) manufactured by Fisher Scientific Limited. Ammonia nitrogen was determined using a titrimetric method, after preliminary distillation as recommended in "Standard Methods"(1992). Samples were distilled using a 1002 distillation unit of kjeltec system manufactured by Tecator, Hoganas, Sweden.

Total petroleum hydrocarbons (TPH) were measured by Horiba- 400 Oil Analyzer with an integral extractor (which can automatically extract oily slibstances using a preset time) manufactured by Horiba Instruments Inc., Irvine, California, USA. Details of the methods adopted for each parameter are described below.

\subsection{Methods Adopted}

\subsubsection{TDS,TSS,COD and $\mathrm{NH}_{3}{ }^{+} \mathrm{N}$}

The wastewater was analyzed for total dissolved solids (TDS)and total suspended solids (TSS) as per procedures 2540-C and 2540-D described in "Standard Methods" (1992).Whatman grade 934-AH filter paper of $55 \mu \mathrm{m}$ was used for filtering wastewater samples. Chemical oxygen demand (COD), of the sample was determined using the closed reflux titrimetric method (5220-C) reported in "Standard Methods"(1992).

Ammonia nitrogen determination of the sample was conducted in two steps. As a first step $1.0 \mathrm{~g}$ of $\mathrm{CaCl}_{2}$ and $1.2 \mathrm{~g}$ of $\mathrm{MgO}$ were added to $50 \mathrm{ml}$ of sample in a digestion tube 
and distilled for a few minutes. An Erlenmeyer flask of $250 \mathrm{ml}$ capacity containing $25 \mathrm{ml}$ boric acid was used as an absorbent to collect the distillate. When the total volume in flask reached $125 \mathrm{ml}$, the distillation step was stopped. The second step involved the titration of distillate against sulfuric acid of $0.02 \mathrm{~N}$, to obtain an end product of pale lavender color.

\subsubsection{TPH}

There are some constituents that represent distinct chemical constituents (ions,compounds or groups of compounds) whereas oils and greases are defined by the method used for their determnation. Determination of oil and grease, as otherwise mentioned as total petroleum hydrocarbons "TPH" in this study, involve quantity determination of groups of substances with similar physical characteristics on the basis of their common solubility in an organic extracting solvent (American Public Health Association, 1992). In spite of the availability of several procedures, instruments and solvents for 'extraction' and measurement of oil, the choice of a method and solvent is still an open contention.

For determination of oil and grease, from liquid samples, three methods are mentioned in the "Standard Methods"(5520) with their significance and limitations. They are(i) partition-gravimetric method,(ii) partition-infrared method and (iii) soxhlet method. Due to certain advantages, in recent times partition-infrared method has found an increasing use. Hence it was selected as a method of choice for this study.The advantages of this method include preservation of volatile hydrocarbons in the sample, lack of interference from suspended solids and colored substances and good precicion.In particular, for liquid samples that contain low levels of oil and grease $(<10 \mathrm{mg} / \mathrm{l})$ this method is reasonably accurate. Anomalies in oil and grease analyses of petroleum wastewaters and their implications were discussed by Sun et al. (1987). It was observed that in certain cases the 
variation in oil concentration from a refinery wastewater varied by 200 percent due to interference of soluble organics which were not extracted fully in the partition-gravimetric method (503A) specified in "Standard Methods"(1992).

Instead of Freon-113 as a solvent, carbon tetrachloride $\left(\mathrm{CCl}_{4}\right)$ has been used in view of its high extraction and sensitivity. As mentioned earlier oil and grease are identified as total petroleum hydrocarbons in this study. TPH analysis involved starting up the oil analyzer as per the operating manual. The analyzer is built to operate at two ranges, 50 and 200 ppms respectively. For this study the analyzer was operated at $200 \mathrm{ppm}$ range, keeping in mind the possible TPH content of wastewaters associated with the API separator. After performing zero and span calibrations, a sample volume of $5 \mathrm{ml}$ was introduced alongwith $20 \mathrm{ml}$ of $\mathrm{CCl}_{4}$. A drop of hydrochloric acid [1:1 with distilled water] was added to the sample and agitated for a minute. After this extraction process the sample was allowed to remain for a minute or two, as this would enable the separation of TPH from the wastewater. TPH content of the sample was observed from in-built digital display. This procedure was repeated until consecutive readings were obtained. On certain occassions, depending on the TPH content the wastewaters associated with API separator were diluted to $1: 2$ or 3 dilutions for analysis. 


\section{Chapter 4}

\section{RESULTS AND DISCUSSIONS}

\subsection{Characteristics of Consumers' COOP refinery wastewater}

Samples of refinery wastewaters-influent to and effluent from API Separator and effluent from the stabilization pond were analyzed, for parameters such as $\mathrm{pH}$, COD, TSS, TDS, ammonia nitrogen and TPH. Their concentrations are given in Tables 4.1 to 4.6,

\subsection{Trends observed in refinery wastewater characteristics.}

The $\mathrm{pH}$ of all three wastewaters varied between 5.1 to 7.5. Sample numbers-3a, $3 \mathrm{~b}$ and $3 \mathrm{c}$ were found to be slightly acidic among the collected samples. Most of the samples especially effluents from API separator and stabilization pond were observed to be near the neutral range. COD values of all three types of wastewater samples collected in this study were found to be similar to the ranges reported in literature. Except for sample numbers 2, 4 and 10 , only 15 to 25 percent difference was observed in most samples associated with API separator. About 150 and 200 percent increase were observed for sample nos. 1(b) and 2(b). Such a wide variation was also observed in SS of these samples. This type of variation is common in any large industry. 
Table 4.1: pH of the refinery wastewater samples

\begin{tabular}{ccccc}
\hline $\begin{array}{c}\text { Week } \\
\text { Number }\end{array}$ & $\begin{array}{c}\text { Sample } \\
\text { collected on }\end{array}$ & (a) & (b) & (c) \\
\hline 1 & Jan 17/95 & 6.90 & 6.60 & 6.10 \\
2 & Jan 25/95 & 7.50 & 7.50 & 6.65 \\
3 & Feb 01/95 & 5.10 & 5.20 & 5.80 \\
4 & Feb 09/95 & 5.20 & 5.60 & 6.10 \\
5 & Mar 23/95 & 6.65 & 6.80 & 6.65 \\
6 & Mar 30/95 & 6.30 & 6.50 & 6.65 \\
7 & Apr 06/95 & 5.70 & 6.00 & 6.72 \\
8 & Apr 13/95 & 6.85 & 6.75 & 6.65 \\
9 & Apr 18/95 & 6.60 & 7.05 & 6.70 \\
10 & Apr 27/95 & 6.65 & 6.75 & 6.50 \\
\hline
\end{tabular}

Table 4.2: COD of the refinery wastewater samples (mg/l)

\begin{tabular}{ccccc}
\hline $\begin{array}{c}\text { Week } \\
\text { Number }\end{array}$ & $\begin{array}{c}\text { Sample } \\
\text { collected on }\end{array}$ & (a) & (b) & (c) \\
\hline 1 & Jan 17/95 & 638 & 957 & 120 \\
2 & Jan 25/95 & 439 & 759 & 108 \\
3 & Feb 01/95 & 1595 & 1276 & 120 \\
4 & Feb 09/95 & 638 & 239 & 96 \\
5 & Mar 23/95 & 1113 & 1113 & 143 \\
6 & Mar 30/95 & 2105 & 1946 & 139 \\
7 & Apr 06/95 & 2390 & 1753 & 143 \\
8 & Apr 13/95 & 1748 & 1429 & 95 \\
9 & Apr 18/95 & 2383 & 2145 & 222 \\
10 & Apr 27/95 & 1907 & 953 & 207 \\
\hline
\end{tabular}

Table 4.3: TSS of the refinery wastewater samples (mg/l)
Week
Sample
(a)
(b)
(c)

Number collected on

\begin{tabular}{ccccc}
\hline 1 & Jan 17/95 & 40 & 70 & 10 \\
2 & Jan 25/95 & 70 & 146 & 46 \\
3 & Feb 01/95 & 100 & 40 & 10 \\
4 & Feb 09/95 & 180 & 60 & 20 \\
5 & Mar 23/95 & 200 & 150 & 50 \\
6 & Mar 30/95 & 510 & 368 & 33 \\
7 & Apr 06/95 & 580 & 363 & 30 \\
8 & Apr 13/95 & 590 & 487 & 130 \\
9 & Apr 18/95 & 508 & 533 & 53 \\
16 & Apr 27/95 & 633 & 300 & 30 \\
\hline
\end{tabular}


Table 4.4:TDS of the refinery wastewater samples (mg/)

\begin{tabular}{|c|c|c|c|c|}
\hline $\begin{array}{l}\text { Week } \\
\text { Number }\end{array}$ & $\begin{array}{c}\text { Sample } \\
\text { collected on }\end{array}$ & (a) & (b) & (c) \\
\hline 1 & $\operatorname{Jan} 17 / 95$ & 2663 & 2647 & 2813 \\
\hline 2 & $\operatorname{Jan} 25 / 95$ & 9033 & 6076 & 5103 \\
\hline 3 & Feb $01 / 95$ & 6403 & 8003 & 5690 \\
\hline 4 & Feb $09 / 95$ & 8690 & 8273 & 8090 \\
\hline 5 & $\operatorname{Mar} 23 / 95$ & 2488 & 2097 & 2873 \\
\hline 6 & Mar 30/95 & 2460 & 2373 & 3307 \\
\hline 7 & Apr 06,95 & 2390 & 1753 & 1430 \\
\hline 8 & Apr 13/95 & 11543 & 11480 & 13993 \\
\hline 9 & Apr $18 / 95$ & 2470 & 2770 & 2933 \\
\hline 10 & Apr 27/95 & 3343 & 2470 & 3373 \\
\hline
\end{tabular}

Table 4.5: $\mathrm{NH}_{3}{ }^{+} \mathrm{N}$ of the refinery wastewater samples (mg/)

\begin{tabular}{ccccc}
\hline $\begin{array}{c}\text { Week } \\
\text { Number }\end{array}$ & $\begin{array}{c}\text { Sample } \\
\text { collected on }\end{array}$ & (a) & (b) & (c) \\
\hline 1 & Jan 17/95 & 6.72 & 7.28 & 9.52 \\
2 & Jan 25/95 & 8.96 & 8.96 & 9.50 \\
3 & Feh 01/95 & 6.72 & 6.72 & 10.08 \\
4 & Fu 09/95 & 6.72 & 6.72 & 8.96 \\
5 & Mar 23/95 & 11.2 & 11.7 & 12.8 \\
6 & Mar 30/95 & 12.8 & 13.44 & 12.88 \\
7 & Apr 06/95 & 14.6 & 15.68 & 13.44 \\
8 & Apr 13/95 & 12.32 & 12.32 & 11.76 \\
9 & Apr 18/95 & 12.32 & 11.76 & 14.56 \\
10 & Apr 27/95 & 15.68 & 16.24 & 15.12 \\
\hline
\end{tabular}

Table 4.6: TPY of the refinery wastewater samples (ppm)

\begin{tabular}{ccccc}
\hline $\begin{array}{c}\text { Week } \\
\text { Number }\end{array}$ & $\begin{array}{c}\text { Sample } \\
\text { collected on }\end{array}$ & (a) & (b) & (c) \\
\hline 1 & Jan 17/95 & 131 & 37 & 8 \\
2 & Jan 25/95 & 161 & 51 & 6 \\
3 & Feb 01/95 & 24 & 14 & 6 \\
3 & Feb 09/95 & 126 & 85 & 8 \\
4 & Mar 23/95 & 34 & 76 & 11 \\
5 & Mar 30/95 & 558 & 309 & 13 \\
6 & Apr 06/95 & 519 & 282 & 13 \\
7 & Apr 13/95 & 555 & 426 & 12 \\
8 & Apr 18/95 & 510 & 438 & 5 \\
9 & Apr 27/95 & 552 & 354 & 8 \\
\hline
\end{tabular}


In fact, it was reported that a consistency in quality or quantity of wastewaters was not observed frequently in Consumers' COOP refinery. This inconsistency was reported due to the changes in process patterns, process upsets, equipment failures, rainfall and effects from plant maintenance. Generally a reasonable removal rate of SS is expected to be associated with API separators. Such removals were not frequently observed during the collection period. Except for samples $3 \mathrm{a}$ and $3 \mathrm{~b}$ distinct difference in TDS content was not observed for wastewaters associated with API separator. An increase in TDS content was observed for 50 percent of effluent samples, say-1, 5, 6 and 9 collected from stabilization pond. Random fluctuation in ammonia nitrogen content was observed for all the wastewater samples during the sampling period. For a wastewater of this nature when subjected to biological treatment, a reduction in $\mathrm{NH}^{+}{ }_{3} \mathrm{~N}$ is expected. More than $50 \%$ of effluent samples from stabilization pond had a higher $\mathrm{NH}_{3}^{+} \mathrm{N}$ content than the effluent samples from API separator. Such an inconsistency could be related to capacity of aerators set up in aeration pond. That is the oxygen introduced could have been used mainly for oxidation of carbon compounds, Also, inconsistencies were observed in total petroleum hydrocarbon content between samples colllected from API separator. Trends observed in characteristics of samples are shown in Figures 4.1 to 4.6 .

\subsection{Toxicity of refinery wastewater samples}

As stated earlier,samples were screened to determine the possible toxicity range of samples. Results of the test are presented in Table 4.7. $\mathrm{IC}_{50}$ of the refinery samples are presented in Table 4.8. Microtox data report for samples $11-\mathrm{a}, \mathrm{b}$ and $\mathrm{c}$ are shown in Appendix A.1 to A.6. Three different toxic patterns observed between influent and effluent of the API separator were as follows:

(i) the influent was extremely higher in toxicity than the effluent of the API separator; 
(ii) the effluent was slightly higher in toxicity than the influent; and

(iii) an almost equal toxicity pattern between influent and effluent.

Among the 11 samples numbers $2 a$ and $6 a$ could be cited as examples of the first case. Almost 200 percent lethality was observed for both samples. Samples $\mathrm{Ib}$ and $8 \mathrm{~b}$ were examples of the second case. They exhibited approximately 300 and 175 percent lethality respectively. Remaining samples represented the third case.

Table 4.7 Light levels $\left(I_{t}\right)$ of the refinery wastewaters, using $2 \%$ screening test.

\begin{tabular}{cccc}
\hline Wastewater & a & b & c \\
\hline Light level $\left(\mathrm{I}_{5}\right)$ & 77 & 69 & 88 \\
\hline
\end{tabular}

$\left(\mathrm{I}_{5}\right)$ Light level

100-75
Recommended primary dilution

No primary dilution required

The trend observed in toxic pattern of these wastewaters during the sampling period are shown in Figures 4.7 and 4.8. Three types of responses were observed in the influent and effluent samples of API separator. They are as follows:

(i) a decreasing pattern in the lethality;

(ii) an increasing pattern in the lethality; and

(iii) a sinusoidal pattern of high and low or low and high.

All the three patterns were found to be influenced by contact time ' $T$ '. Samples. $2 a, 2 b, 5 b$, 6a, 7a, 9a, and $11 \mathrm{a}$ exhibited the third type of response. Of the remaining influent samples , majority were found to reflect the first case. 
Table 4.8: IC50 (in \%) of the various refinery wastewater samples

\begin{tabular}{|c|c|c|c|c|c|}
\hline $\begin{array}{c}\text { Week } \\
\text { numbers }\end{array}$ & $\begin{array}{c}\text { Sample } \\
\text { collected } \\
\text { on }\end{array}$ & $\begin{array}{c}\text { Contact } \\
\text { time ' } \mathrm{T} \text { ' } \\
\text { between } \\
\text { reagent and } \\
\text { sample }\end{array}$ & (a) & (b) & (c) \\
\hline \multirow[t]{3}{*}{1} & $\operatorname{Jan} 17 / 95$ & 1 & 4.5285 & 1.4794 & 32.3399 \\
\hline & & 15 & 4.8528 & 1.7182 & 29.9865 \\
\hline & & 30 & 4.8915 & 2.0216 & 30.1830 \\
\hline \multirow[t]{3}{*}{2} & $\operatorname{Jan} 25 / 95$ & 1 & 4.7612 & 7.7452 & 57.9572 \\
\hline & & 15 & 4.3473 & 6.9742 & 47.0726 \\
\hline & & 30 & 4.8915 & 7.0068 & 36.6070 \\
\hline \multirow[t]{3}{*}{3} & Feb 01/95 & 1 & 2.4811 & 3.0316 & 30.8265 \\
\hline & & 15 & 2.7876 & 3.1229 & 27.1552 \\
\hline & & 30 & 3.0482 & 3.4204 & 27.7326 \\
\hline \multirow[t]{3}{*}{4} & Feb 09/95 & 1 & 2.4548 & 2.4519 & 34.7268 \\
\hline & & 15 & 2.6062 & 2.7684 & 27.9211 \\
\hline & & 30 & 2.6542 & 3.3849 & 28.9952 \\
\hline \multirow[t]{3}{*}{5} & Feb $17 / 95$ & 1 & 2.2713 & 2.3022 & 12.7889 \\
\hline & & 15 & 2.2988 & 2.1607 & 25.9329 \\
\hline & & 30 & 2.6003 & 2.5039 & 26.6323 \\
\hline \multirow[t]{3}{*}{6} & Mar 23/95 & 1 & 1.8978 & 3.0224 & 61.8570 \\
\hline & & 15 & 2.7703 & 3.1917 & 57.7519 \\
\hline & & 30 & 2.5808 & 3.4776 & 56.3584 \\
\hline \multirow[t]{3}{*}{7} & Mar 30/95 & 1 & 2.4232 & 3.2128 & 52.6050 \\
\hline & & 15 & 2.6670 & 3.2346 & 55.3821 \\
\hline & & 30 & 2.6054 & 3.5980 & 52.4764 \\
\hline \multirow[t]{3}{*}{8} & Apr 06/95 & 1 & 2.7595 & 1.7371 & 68.3427 \\
\hline & & 15 & 2.5494 & 1.7412 & 61.8968 \\
\hline & & 30 & 2.4848 & 1.9705 & 56.6291 \\
\hline \multirow[t]{3}{*}{9} & Apr $13 / 95$ & 1 & 1.2830 & 1.7747 & 39.0832 \\
\hline & & 15 & 1.4542 & 1.9408 & 20.3159 \\
\hline & & 30 & 1.3965 & 2.2188 & 12.8340 \\
\hline \multirow[t]{3}{*}{10} & Apr $17 / 95$ & 1 & 0.8545 & 0.9835 & 72.7393 \\
\hline & & 15 & 0.7582 & 0.9095 & 71.8942 \\
\hline & & 30 & 0.7404 & 0.8595 & 63.2632 \\
\hline \multirow[t]{3}{*}{11} & Apr 27/95 & 1 & 1.4946 & 1.5694 & 55.4242 \\
\hline & & 15 & 1.3817 & 1.3237 & 52.3195 \\
\hline & & 30 & 1.4910 & 1.4027 & 50.3132 \\
\hline
\end{tabular}


Toxic patterns similar to those of wastewaters associated with API separators was observed for the effluent from stabilization pond. The $\mathrm{IC}_{50}$ values varied between 12 to 73 percent of wastewater samples. More than half of the collected samples produced an $\mathrm{IC}_{50}$ of less than 50 percent, giving an idea of the toxic nature of sample influenced by some unknown components. The usual pattern observed in a majority of samples was a proportional increase in toxicity with time as shown in Figure 4.9 ; because of the sensitivity of the bioassay. It has been reported that the sensitivity of Microtox increased with the exposure time (Indorato et al, 1984: and Vasseur et al,1986).

\subsection{Statistical analysis of $I_{50}$ and refinery wastewater characteristics.}

The collected data were statistically analyzed to identify the existence of any relationship between wastewater characteristics and Microtox $\mathrm{IC}_{50}$ values. A software package 'Statistica' produced by Statsoft ${ }^{\mathrm{TM}}$, Inc. for Windows was used to analyze both data by a simple regression analysis. Also, a distribution analysis of the data was done and it is presented in Tables 4.9 and 4.10. Distribution analysis of wastewater samples showed reasonable consistency in the observed values. Some of the low correlation coefficient(r) values observed could be due to the limited number of samples. Characteristics of all these wastewaters were not found to be symmetric. Barring a few, most of them were found to be skewed to the left. Eventhough, skewness of effluent pond TSS was found to be the highest among all samples, earlier analysis of correlation coefficients proved to be consistent.

Simple distribution analysis of wastewater toxicity also showed a remarkable consistency in the observed values. Wastewaters associated with API separator were found to be skewed to right, whereas effluent pond values were oriented towards left side. In spite of this, profound deviation was not observed.The statistical parameters of interest from this study were correlation coefficient(r), ' $t$ ' statistic, ' $F$ ' statistic and prob $>F$ ( $P$ value for $F$ statistic). 


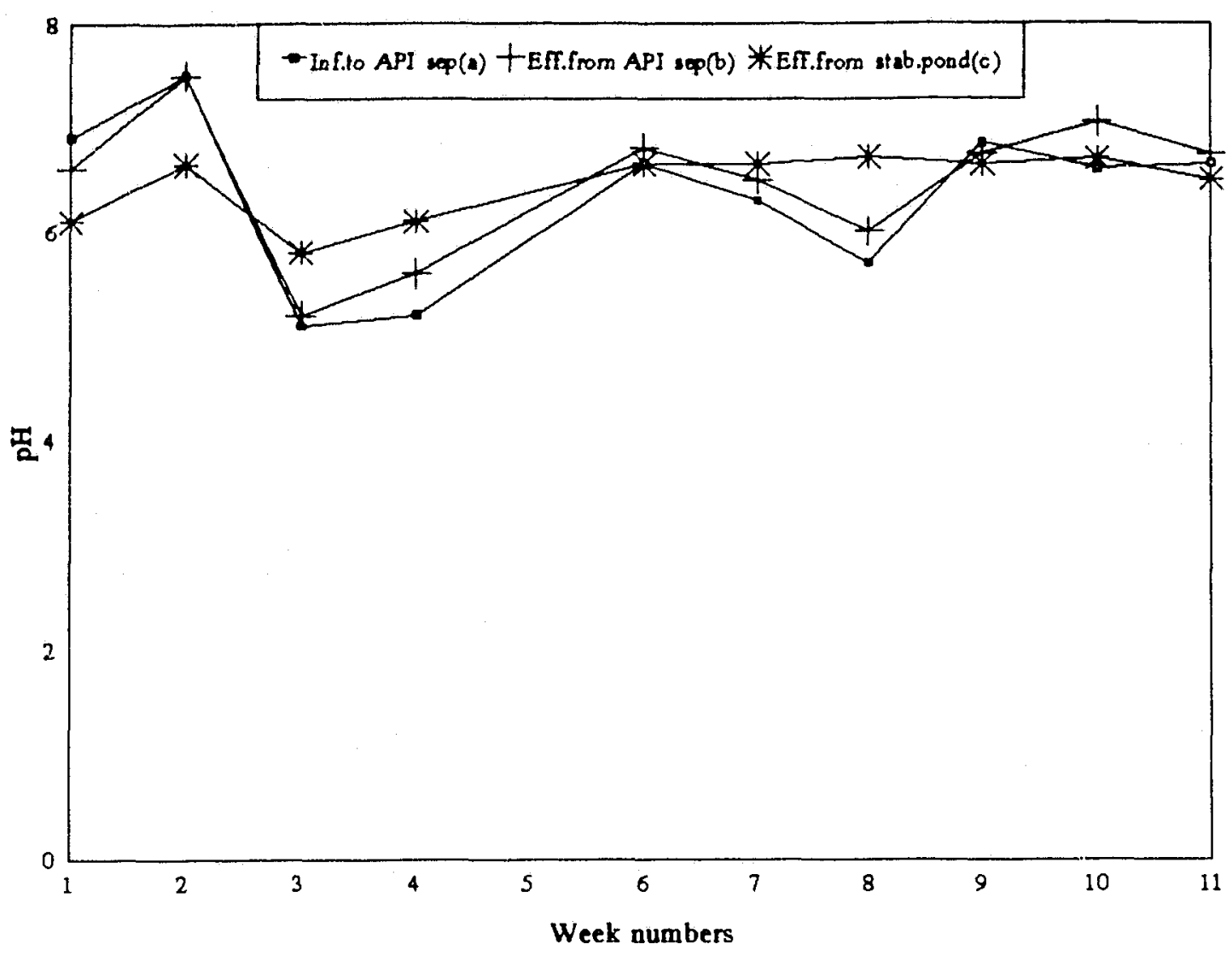

Figure 4.1 Trend in $\mathrm{pH}$ of wastewater samples

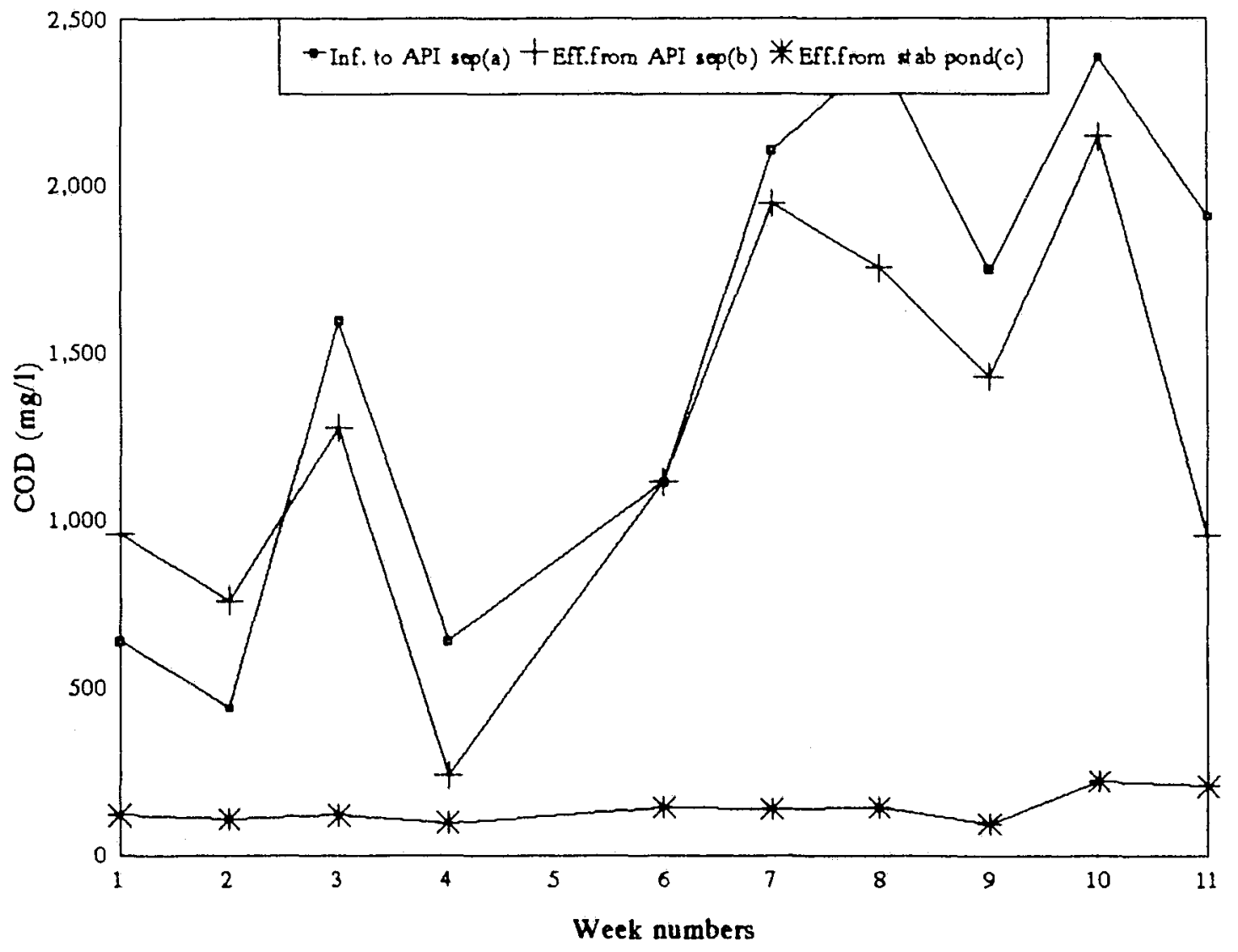

Figure 4.2 Trend in COD of wastewater samples 


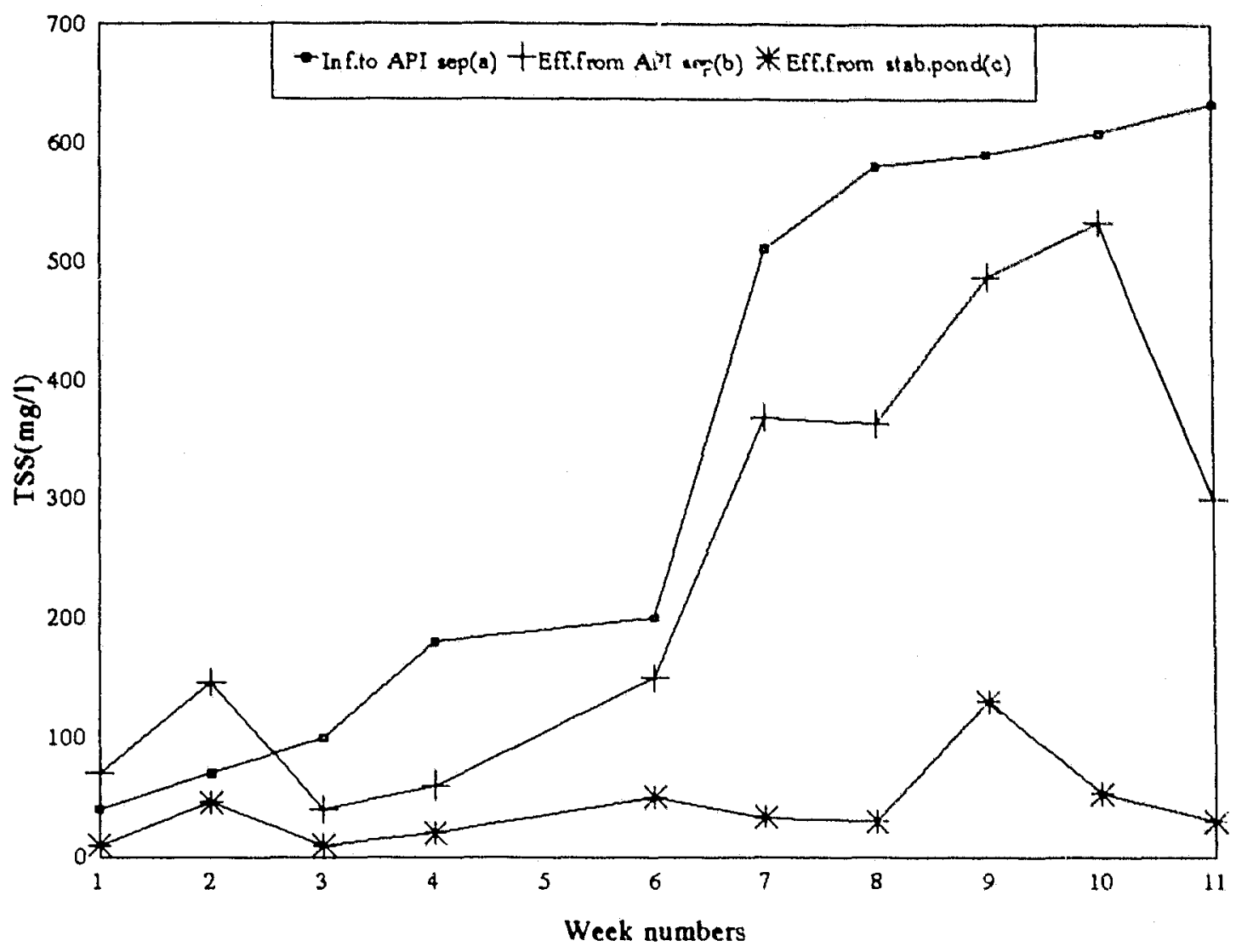

Figure 4.3 Trend in TSS of wastewater samples

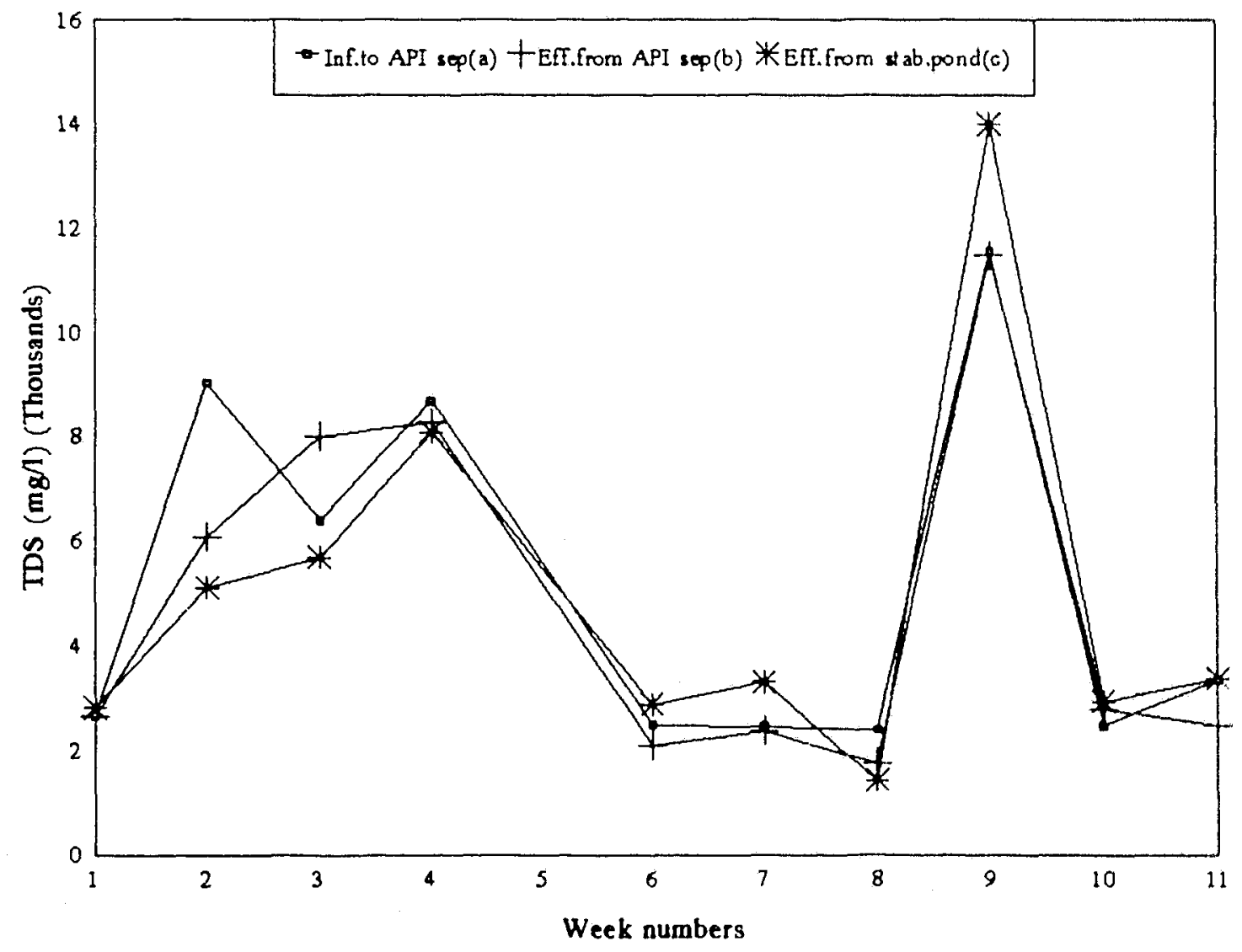

Figure 4.4 Trend in TDS of wastewater samples 


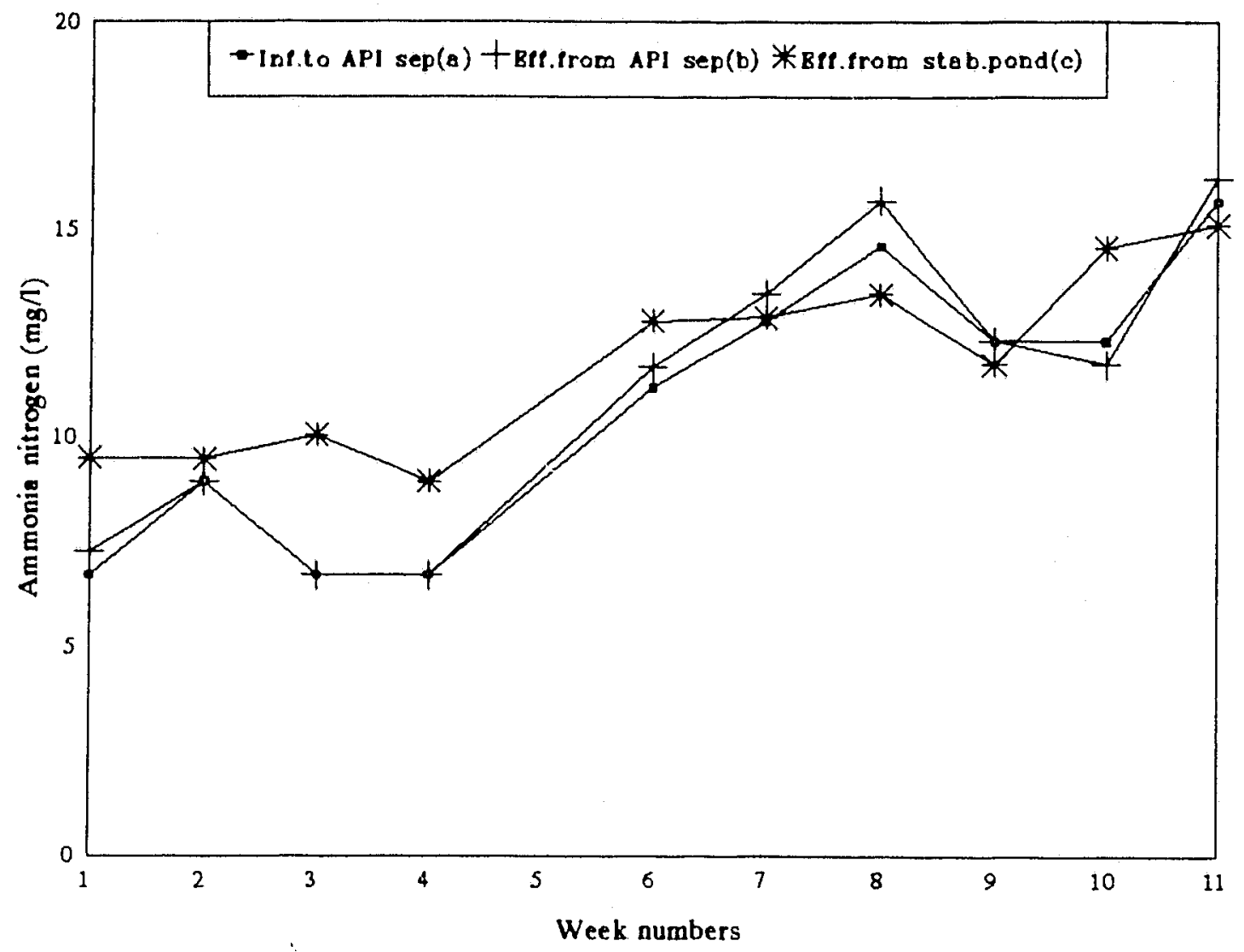

Figure 4.5 Trend in ammonia nitrogen of wastewater samples

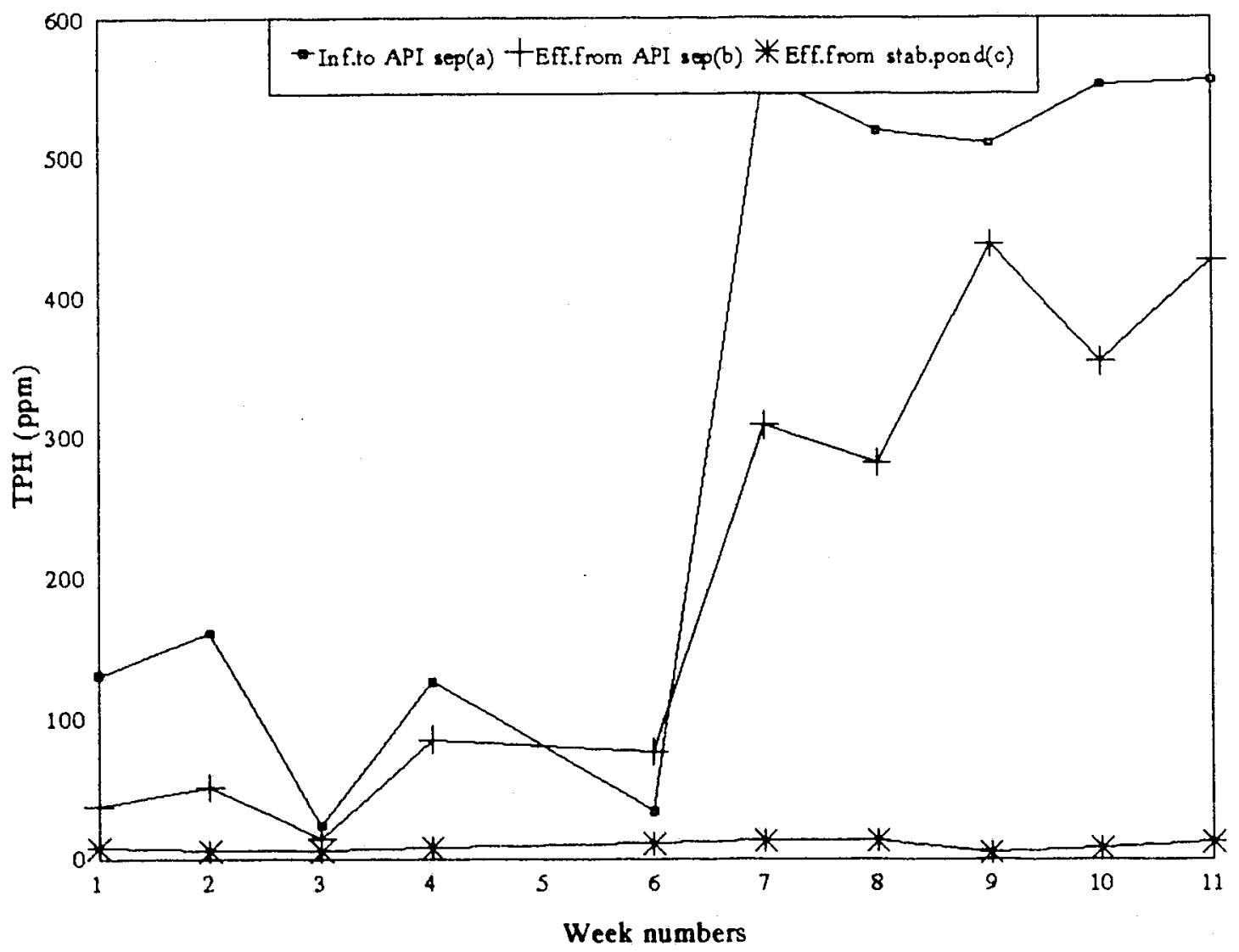

Figure 4.6 Trend in TPH of wastewater samples 


\section{Influent Concentration, \%}

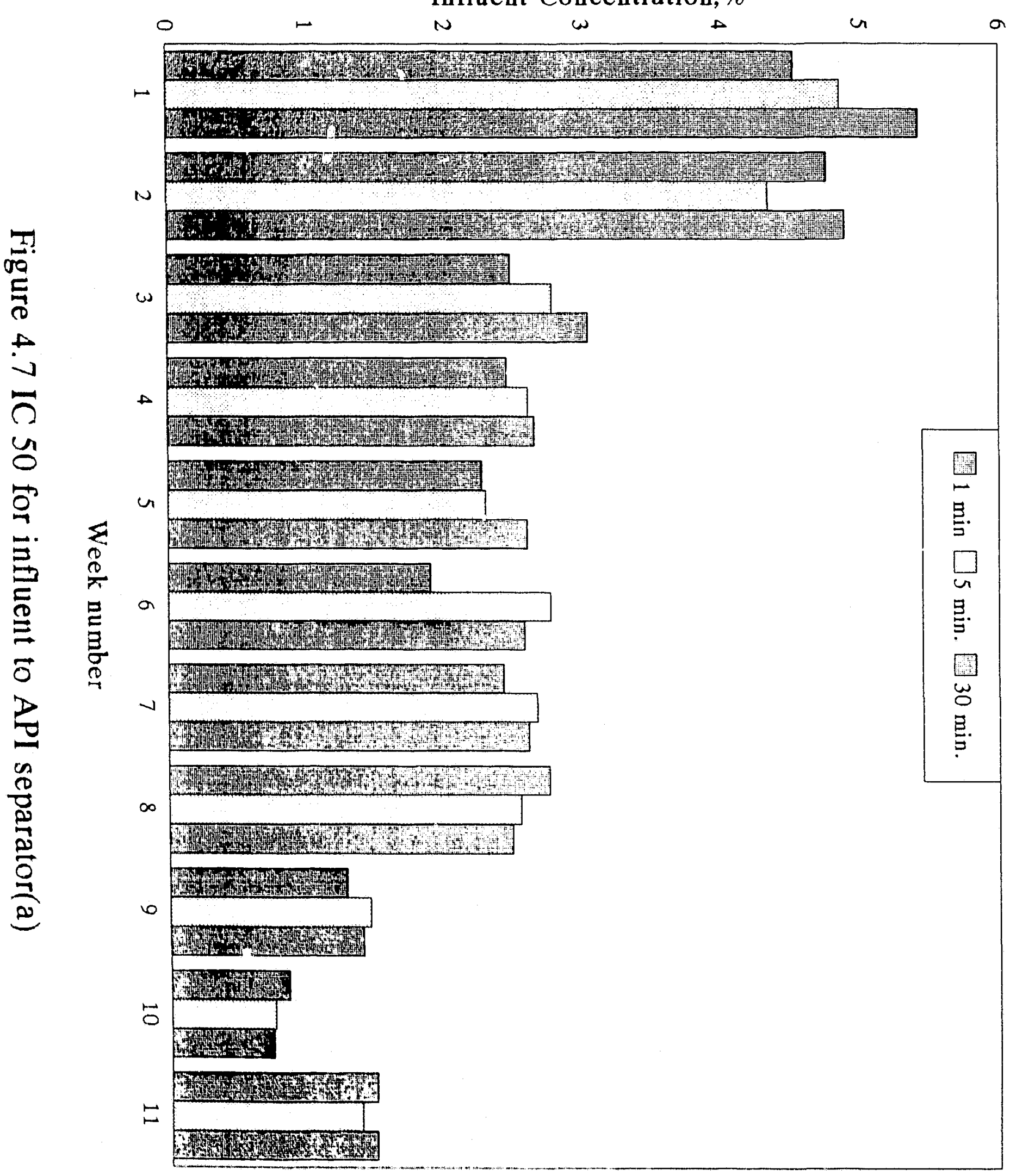




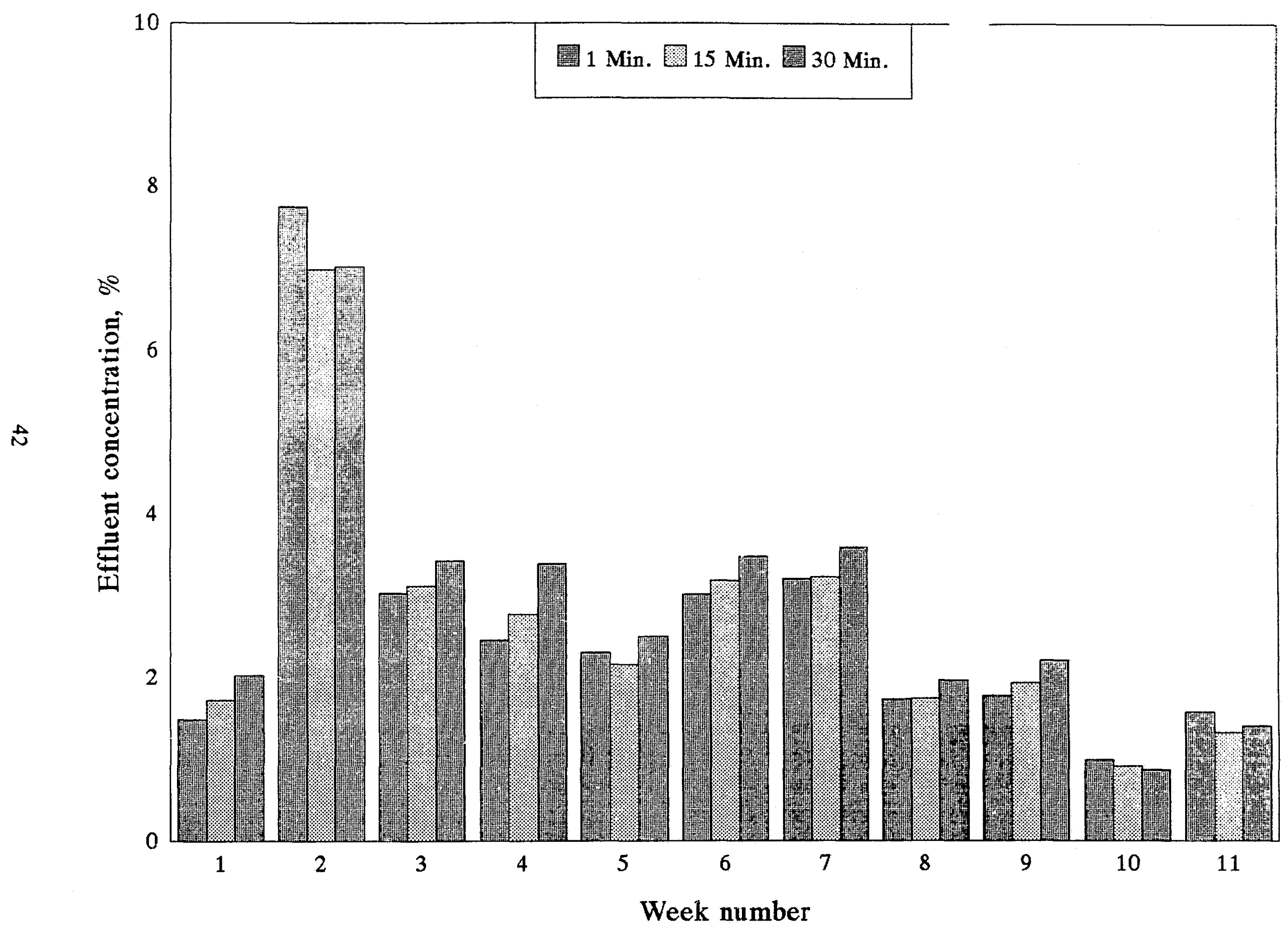

Figure 4.8 IC 50 for effuent from API separator(b) 
Effluent Concentration, \%

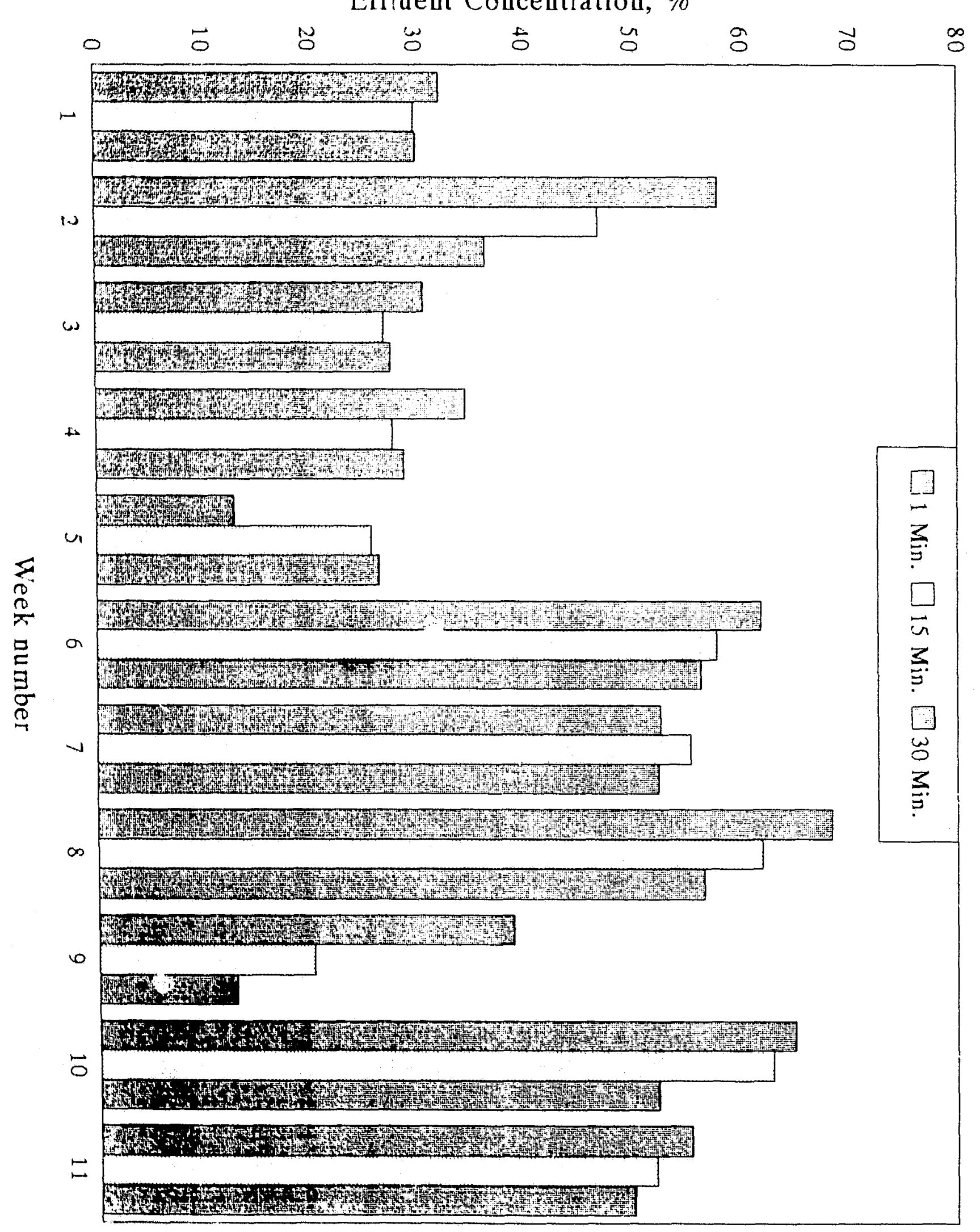


Results obtained from this statistical analysis for all three wastewaters are shown in Tables 4.11 to 4.13. Graphical representation of these analysis expressing the linear relationshipbetween wastewater parameters and toxicity concentrations are shown in Figures 4.10 (a), (b) and (c) to 4.15 (a), (b) and (c). This analysis is based on the linear relationship beteen an independent variable $(\mathrm{X})$ and a dependent variable $(\mathrm{Y})$. In this study, the independent variable happened to be wastewater parameter and dependent variable to be toxicity values $\left(\mathrm{IC}_{50}\right)$. Resultant model of this graphical analysis is of the form $y=\alpha+\beta x$

where ' $\beta$ ' depicts slope of regression line. Nature of relationship between ' $x$ ' and ' $y$ ' is expressed by ' $\beta$ '. Sometimes the difference in unit measurement of variables would lead to a situation, where magnitude of the slope cannot be used to asses the strength of linear relationship. Therefore one more measurement is used to express the degree of association between ' $\mathrm{X}$ ' and ' $\mathrm{Y}$ '. This coefficient has no units of ineasurement associated with it. Thus the magnitude of absolute value of ' $r$ ' expresses the strength of linear association between ' $\mathrm{X}$ ' and ' $\mathrm{Y}$ '. In all cases $-1 \leq \mathrm{r} \geq+1$.

The ' $t$ ' statistic is a test statistic used to estimate the probabilities from a distribution that is normal, symmetrical, unimodal and not a large variance. Where accuracy is desired the ' $t$ ' distribution is generally used. Further, ' $F$ ' test is used to determine, whether the linear association explains significant variability in the ' $\mathrm{Y}$ ' variable or not. Prob $>\mathrm{F}$ is the ' $\mathrm{P}$ ' value for the ' $F$ ' statistic which indicates that there would be a significant linear relationship at 0.05 level of significance.(Dowdy and Wearden, 1985). 
Table 4.9: Distribution analysis of the toxicity of refinery wastewater samples

\begin{tabular}{cccccccc}
\hline $\begin{array}{c}\text { Wastewater } \\
\text { sample }\end{array}$ & $\begin{array}{c}\text { Contact } \\
\text { time ' } \mathrm{T} \text { ' }\end{array}$ & \multicolumn{5}{c}{ Toxicity ' $\mathrm{IC}_{\mathbf{5 0}}$ ' in \%. } \\
\hline & in min. & Mean & Median & Mode & $\begin{array}{c}\text { Standard } \\
\text { deviation }\end{array}$ & Skewness & Kurtosis \\
Influent to & 1 & 2.47 & 2.42 & $\ldots$ & 1.22 & 0.91 & 0.38 \\
API & 15 & 2.59 & 2.61 & $\ldots$ & 1.2 & 0.54 & 0.28 \\
Separator & 30 & 2.67 & 2.60 & 4.892 & 1.3 & 0.62 & 0.19 \\
Effluent & 1 & 2.67 & 2.3 & $\ldots$ & 1.83 & 2.42 & 6.84 \\
from API & 15 & 2.64 & 2.16 & $\ldots$ & 1.64 & 2.01 & 5.17 \\
Separator & 30 & 2.9 & 2.5 & $\ldots$ & 1.64 & 1.57 & 3.7 \\
Effluent & 1 & 47.15 & 52.61 & $\ldots$ & 18.5 & -0.37 & -0.66 \\
from & 15 & 43.42 & 47.07 & $\ldots$ & 17.66 & -0.15 & -1.56 \\
$\begin{array}{c}\text { Stabilization } \\
\text { pond }\end{array}$ & 30 & 40.18 & 36.61 & $\ldots$ & 16.26 & -0.1 & -1.28 \\
\hline
\end{tabular}


Table 4.10: Distribution ar alysis of the characteristics of refinery wastewater samples

\begin{tabular}{|c|c|c|c|c|c|c|c|}
\hline \multirow{2}{*}{$\begin{array}{c}\text { Wastewater } \\
\text { sample }\end{array}$} & \multirow{2}{*}{$\begin{array}{l}\text { Waste } \\
\text { Water } \\
\text { charact- } \\
\text { eristics } \\
\end{array}$} & \multicolumn{6}{|c|}{ Distribution analysis } \\
\hline & & Mean & Median & Mode & $\begin{array}{l}\text { Standard } \\
\text { deviation }\end{array}$ & Skewness & Kurtosis \\
\hline Influent to & $\mathrm{pH}$ & 6.3 & 6.6 & 6.65 & 0.78 & -0.53 & -0.58 \\
\hline API & COD & 1591 & 1748 & $\ldots$ & 717 & -0.58 & -1.01 \\
\hline \multirow[t]{4}{*}{ separator } & TSS & 375 & 508 & $\ldots$ & 231 & -0.27 & -2.17 \\
\hline & TDS & 5148 & 3003 & $\ldots$ & 3474 & 0.98 & 1.90 \\
\hline & $\mathrm{NH}_{3}-\mathrm{N}$ & 10.8 & 11.8 & 6.72 & 3.3 & -0.09 & -1.45 \\
\hline & TPH & 350 & 510 & $\ldots$ & 222.5 & -0.34 & -2.29 \\
\hline \multirow{6}{*}{$\begin{array}{l}\text { Effluent } \\
\text { from API } \\
\text { separator }\end{array}$} & $\mathrm{pH}$ & 6.5 & 6.7 & 6.8 & 0.7 & -0.63 & 0.04 \\
\hline & COD & 1290 & 1276 & $\ldots$ & 605 & -0.25 & -0.41 \\
\hline & TSS & 272 & 300 & $\ldots$ & 181 & 0.09 & -1.5 \\
\hline & TDS & 4794 & 2709 & $\ldots$ & 3420 & -0.34 & 3.85 \\
\hline & $\mathrm{NH}_{3}-\mathrm{N}$ & 11.1 & 11.7 & 6.72 & 3.5 & 0.06 & -1.36 \\
\hline & ТРH & 193 & 85 & $\ldots$ & 170 & 0.53 & -1.76 \\
\hline \multirow{6}{*}{$\begin{array}{c}\text { Effluent } \\
\text { from } \\
\text { stabilization } \\
\text { pond }\end{array}$} & $\mathrm{pH}$ & 6.5 & 6.65 & 6.65 & 0.3 & -1.18 & -0.04 \\
\hline & COD & 141 & 139 & 143 & 46 & 0.96 & -0.16 \\
\hline & TSS & 44.7 & 33 & 30 & 34.9 & 2.10 & 5.32 \\
\hline & TDS & 4960 & 3340 & $\ldots$ & 3693 & -0.36 & 3.85 \\
\hline & $\mathrm{NH}_{3}-\mathrm{N}$ & 11.9 & 12.3 & $\ldots$ & 2.2 & 0.05 & -1.6 \\
\hline & $\mathrm{TPH}$ & 9.3 & 8 & 8.0 & 3.00 & -0.02 & -1.6 \\
\hline
\end{tabular}


Table 4.11: Application of wastewater quality parameters for predicting toxicity response (Influent to API Separator)

\begin{tabular}{|c|c|c|c|c|c|c|}
\hline Linear regression & Waste & er quali & aramets & for infle & it to API & arator \\
\hline $\begin{array}{l}\text { Microtox (acute) } \\
\text { IC }_{50} \\
\text { Imin exposure }\end{array}$ & $\mathrm{pH}$ & $\mathrm{COD}^{\mathrm{b}}$ & TSS $^{\mathrm{C}}$ & TDS $^{\mathrm{d}}$ & $\mathrm{NH}_{3}-\mathrm{N}^{\mathrm{e}}$ & $\mathrm{TPH}^{\top}$ \\
\hline $\mathrm{r}$ & 0.24 & 0.62 & 0.61 & 0.08 & 0.54 & 0.55 \\
\hline F & 0.47 & 4.43 & 4.04 & 0.05 & 3.29 & 3.0 \\
\hline t-ratio & 0.69 & -2.11 & -2.01 & 0.21 & -1.81 & -1.73 \\
\hline $\begin{array}{l}\text { Significant }(\mathrm{p} \leq 0.05)^{\mathrm{g}} \\
15 \mathrm{~min} \text { exposure }\end{array}$ & $\ldots$ & $\cdots$ & $\cdots$ & $\cdots$ & $\cdots$ & $\ldots$ \\
\hline$r$ & 0.19 & 0.69 & 0.73 & 0.02 & 0.62 & 0.68 \\
\hline $\mathbf{F}$ & 0.3 & 6.18 & 8.08 & 0.002 & 5.08 & 5.91 \\
\hline t-ratio & 0.55 & -2.49 & -2.84 & 0.05 & -2.25 & -2.43 \\
\hline $\begin{array}{l}\text { Significant }(\mathrm{p} \leq 0.05)^{\mathrm{g}} \\
30 \text { min exposure }\end{array}$ & $\ldots$ & $\sqrt{ }$ & $\sqrt{ }$ & $\ldots$ & $\sqrt{ }$ & $\sqrt{ }$ \\
\hline $\mathrm{r}$ & 0.2 & 0.7 & 0.75 & 0.08 & 0.64 & 0.66 \\
\hline $\mathrm{F}$ & 0.35 & 6.7 & 8.8 & 0.06 & 5.44 & 5.35 \\
\hline t-ratio & 0.59 & -2.59 & -2.97 & 0.24 & -2.33 & -2.31 \\
\hline Significant $(p \leq 0.05)^{g}$ & $\ldots$ & $\sqrt{ }$ & $\sqrt{ }$ & $\ldots$ & $\sqrt{ }$ & $\sqrt{ }$ \\
\hline
\end{tabular}

${ }^{a}$ Microtox values expressed as $\%$ toxicity values for correlation with wastewater quality parameters

${ }^{5}$ Chemical oxygen demand

${ }^{c}$ Total suspended solids

${ }^{\mathrm{d}}$ Total dissolved solids

${ }^{\mathfrak{e}}$ Ammonia Nitrogen $\mathrm{NH}_{3}{ }^{+} \mathrm{N}$

${ }^{f}$ Total petroleum hydrocabons

${ }^{\mathrm{B}}$ Check mark indicates statistically significant regression 
Table 4.12: Application of wastewater quality parameters for predicting toxicity response ( Emuent from API separator)

\begin{tabular}{|c|c|c|c|c|c|c|}
\hline \multirow{2}{*}{$\begin{array}{l}\text { Linear regression } \\
\text { statistics for bioassay } \\
\text { test }^{\mathrm{a}} \\
\text { Microtox (acute) } \\
\text { IC }_{50} \\
\text { I min exposure }\end{array}$} & \multicolumn{6}{|c|}{$\begin{array}{l}\text { Wastewater quality parameters for effluent from API } \\
\text { Separator }\end{array}$} \\
\hline & $\mathrm{pH}$ & $\mathrm{COD}^{\mathrm{b}}$ & $\mathrm{TSS}^{\mathrm{c}}$ & $\mathrm{TDS}^{\mathrm{d}}$ & $\mathrm{NH}_{3}-\mathrm{N}^{\mathrm{e}}$ & $\mathrm{TPH}^{\mathrm{r}}$ \\
\hline$r$ & 0.32 & 0.43 & 0.49 & 0.17 & 0.29 & 0.63 \\
\hline F & 0.92 & 1.61 & 2.22 & 0.24 & 0.71 & 4.64 \\
\hline t-ratio & 0.96 & -1.27 & -1.49 & 0.48 & -0.85 & -2.16 \\
\hline $\begin{array}{l}\text { Significant }(\mathrm{p} \leq 0.05)^{\mathrm{g}} \\
15 \text { min exposure }\end{array}$ & $\cdots$ & $\ldots$ & $\ldots$ & $\ldots$ & $\ldots$ & $\cdots$ \\
\hline$r$ & 0.25 & 0.48 & 0.55 & 0.21 & 0.36 & 0.63 \\
\hline $\mathbf{F}$ & 0.54 & 2.12 & 3.0 & 0.38 & 1.18 & 4.67 \\
\hline t-ratio & 0.73 & -1.46 & $-1,73$ & 0.62 & -1.08 & -2.16 \\
\hline Significant $(p \leq 0.05)^{\mathrm{g}}$ & $\cdots$ & $\ldots$ & $\cdots$ & $\cdots$ & $\ldots$ & $\cdots$ \\
\hline 30 min exposure & & & & & & \\
\hline r & 0.18 & 0.55 & 0.60 & 0.25 & 0.40 & 0.63 \\
\hline $\mathbf{F}$ & 0.26 & 3.0 & 3.87 & 0.52 & 1.53 & 4.56 \\
\hline t-ratio & 0.51 & -1.73 & -1.97 & 0.62 & -1.24 & -2.14 \\
\hline Significant $(\mathrm{p} \leq 0.05)^{\mathrm{g}}$ & $\ldots$ & $\ldots$ & $\ldots$ & $\ldots$ & $\ldots$ & $\ldots$ \\
\hline
\end{tabular}

"Microtox values expressed as \% toxicity values for correlation with wastewater quality parameters

${ }^{6}$ Chemical oxygen demand

${ }^{c}$ Total suspended solids

${ }^{\mathrm{d}}$ Total dissolved solids

${ }^{\mathrm{e}}$ Ammonia Nitrogen $\mathrm{NH}_{3}{ }^{+} \mathrm{N}$

' Total petroleum hydrocabons

${ }^{\mathfrak{B}}$ Check mark indicates statistically significant regression 
Table 4.13: Application of water quality parameters for predicting toxicity response ( Emuent from stabilization pond )

\begin{tabular}{|c|c|c|c|c|c|c|}
\hline $\begin{array}{l}\text { Linear regression } \\
\text { statistics for bioassay } \\
\text { test }^{\mathrm{a}} \\
\text { Microtox (acute) }\end{array}$ & \multicolumn{6}{|c|}{$\begin{array}{l}\text { Wastewater quality parameters for effluent from stabilization } \\
\text { pond }\end{array}$} \\
\hline $\begin{array}{l}\text { Microtox (acute) } \\
\text { IC }_{50} \\
\text { Imin exposure }\end{array}$ & $\mathrm{pH}$ & $\mathrm{COD}^{6}$ & $\mathrm{TSS}^{\mathrm{c}}$ & $\mathrm{TDS}^{\mathrm{d}}$ & $\mathrm{NH}_{3}-\mathrm{N}^{\mathrm{c}}$ & $\mathrm{TPH}^{\mathrm{T}}$ \\
\hline $\mathrm{r}$ & 0.82 & 0.66 & 0.001 & 0.53 & 0.73 & 0.06 \\
\hline $\mathbf{F}$ & 16.62 & 5.48 & 0 & 3.11 & 8.85 & 0.03 \\
\hline t-ratio & 4.08 & 2.34 & -0.004 & -1.76 & 2.98 & -0.16 \\
\hline $\begin{array}{l}\text { Significant }(p \leq 0.05)^{\mathrm{g}} \\
15 \mathrm{~min} \text { exposure }\end{array}$ & $\sqrt{ }$ & $\sqrt{ }$ & $\cdots$ & $\cdots$ & $\sqrt{ }$ & $\cdots$ \\
\hline $\mathbf{r}$ & 0.67 & 0.76 & 0.25 & 0.73 & 0.73 & 0.08 \\
\hline $\mathbf{F}$ & 6.43 & 9.41 & 0.47 & 9.12 & 9.37 & 0.05 \\
\hline t-ratio & 2.54 & 3.07 & -0.69 & -3.02 & 3.06 & -0.22 \\
\hline Significant $(p \leq 0.05)^{g}$ & $\sqrt{ }$ & $\sqrt{ }$ & $\ldots$ & $\sqrt{ }$ & $\sqrt{ }$ & $\ldots$ \\
\hline 30 min exposure & & & & & & \\
\hline r & 0.53 & 0.76 & 0.4 & 0.81 & 0.72 & 0.72 \\
\hline $\mathbf{F}$ & 3.12 & 9.73 & 1.32 & 15.64 & 8.56 & 8.56 \\
\hline t-ratio & 1.77 & 3.12 & -1.15 & -3.95 & 2.93 & 2.93 \\
\hline Significant $(\mathrm{p} \leq 0.05)^{\mathrm{g}}$ & $\ldots$ & $\sqrt{ }$ & $\ldots$ & $\sqrt{ }$ & $\sqrt{ }$ & $\ldots$ \\
\hline
\end{tabular}

${ }^{a}$ Microtox values expressed as \% toxicity values for correlation with wastewater quality parameters

${ }^{6}$ Chemical oxygen demand

" Total suspended solids

Total dissolved solids

e Ammonia Nitrogen $\mathrm{NH}_{3}{ }^{+} \mathrm{N}$

${ }^{f}$ Total petroleum hydrocabons

${ }^{\mathrm{g}}$ Check mark indicates statistically significant regression 


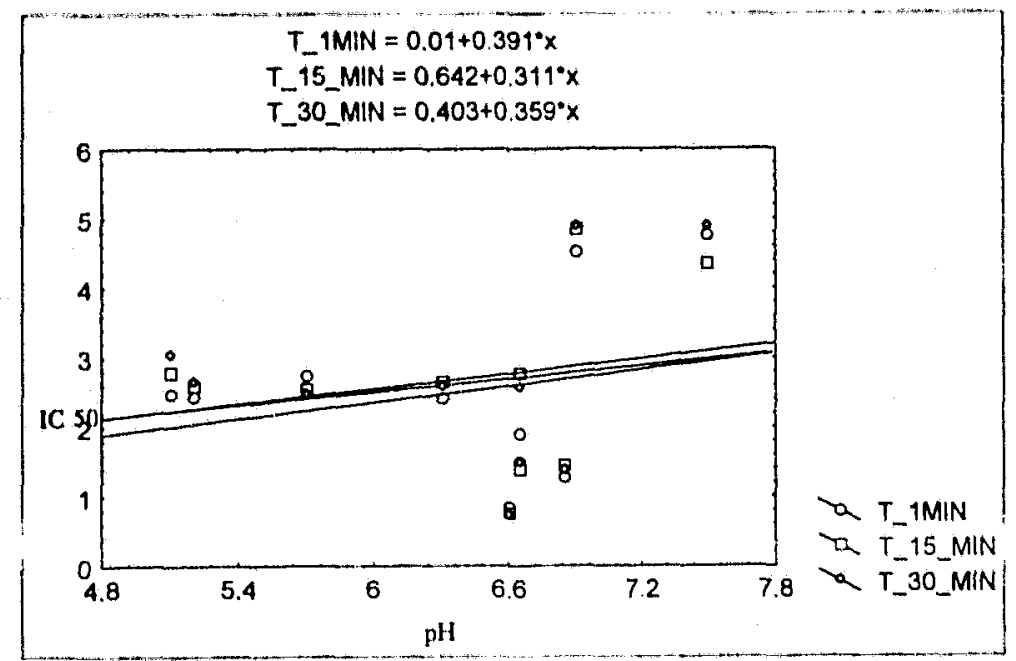

Figure 4.10 (a) $\mathrm{pH}$ vs Toxicity concentrations $\mathrm{IC}_{50}$ at contact times $\mathrm{T}=1,15$ and 30 min. for influent to API Separator

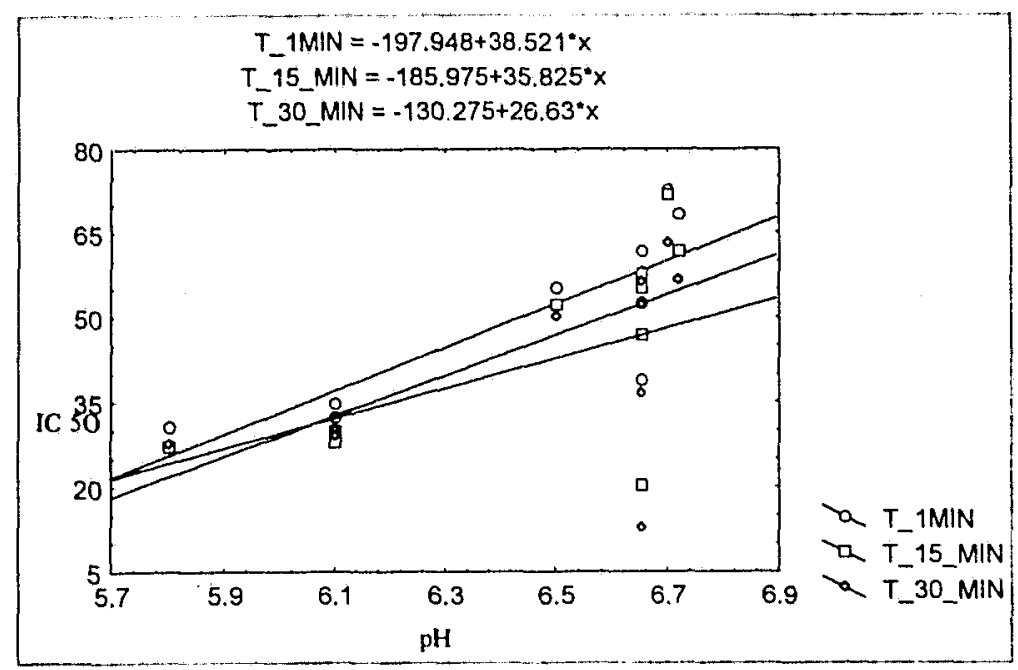

Fig 4.10(c) $\mathrm{pH}$ vs Toxicity concentrations $\mathrm{IC}_{50}$ at contact times $\mathrm{T}=1,15$ and $30 \mathrm{~min}$. for effluent from stabilization pond

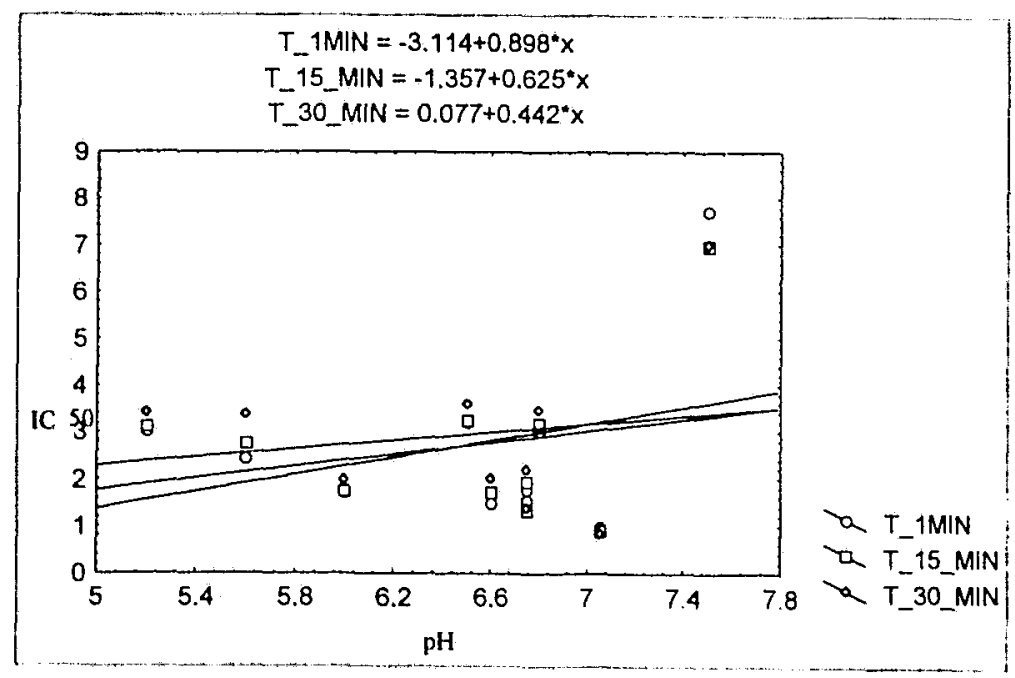

Fig 4.10 (b) $\mathrm{pH}$ vs Toxicity concentrations $\mathrm{IC}_{50}$ at contact times $T=1,15$ and $30 \mathrm{~min}$ tor effluent from API Separator 


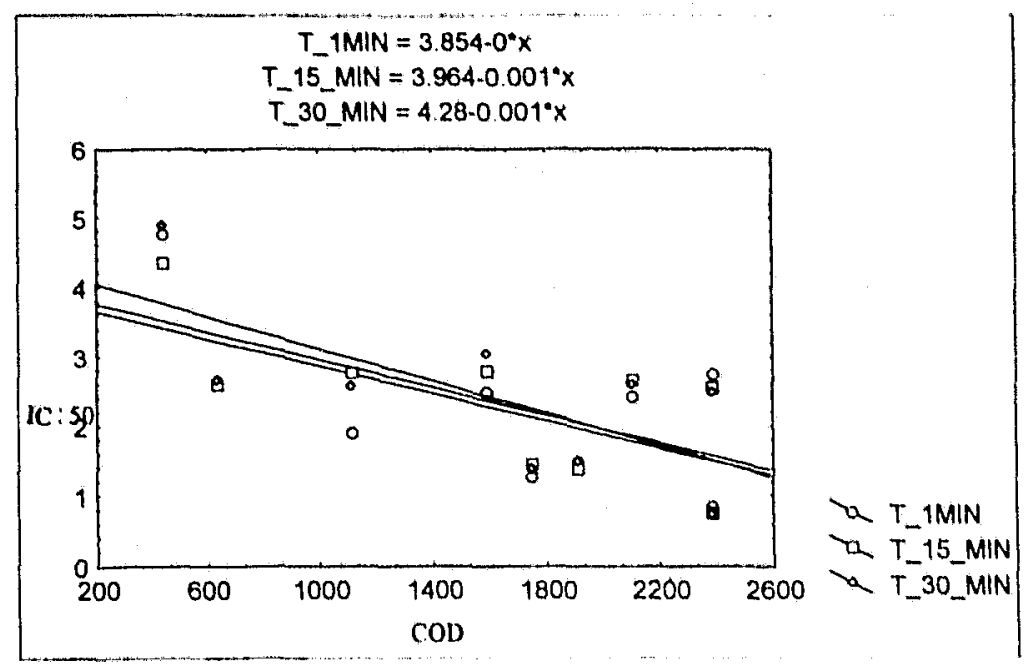

Figure:4. 1 (b) $C O D$ vs Toxicity values $\mathrm{IC}_{50}$ at contact times $\mathrm{T}=1,15$ und 30 min for influent to API Separator

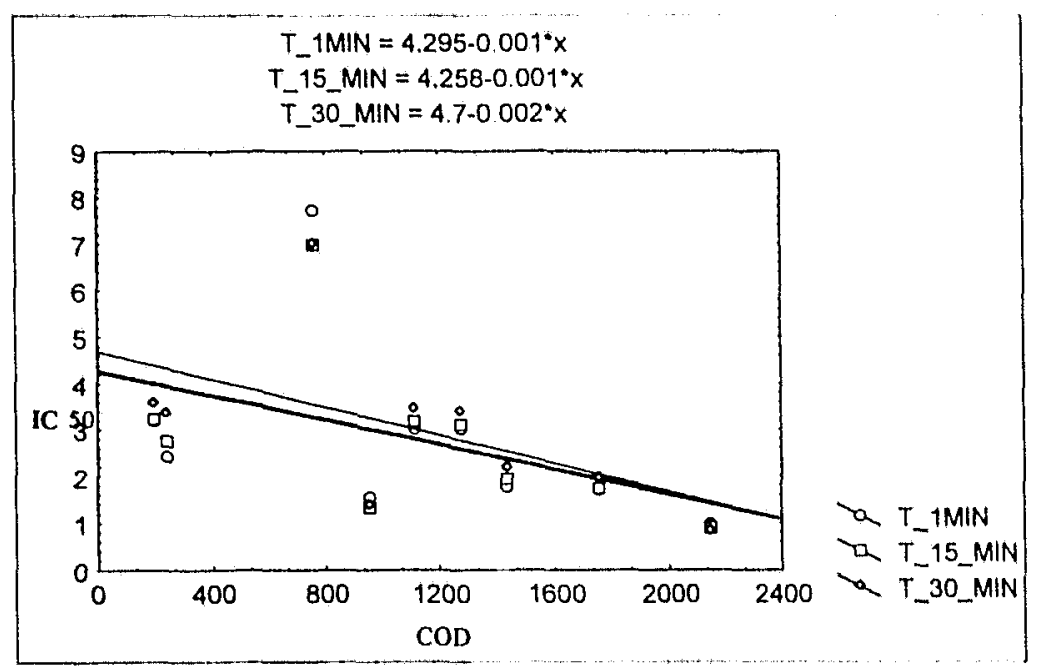

Figure: $4 . I$ ( (b) $C O D$ vs Toxicity values $I_{50}$ at contact times $T=1,15$ and 30 min for effluent from API Separator

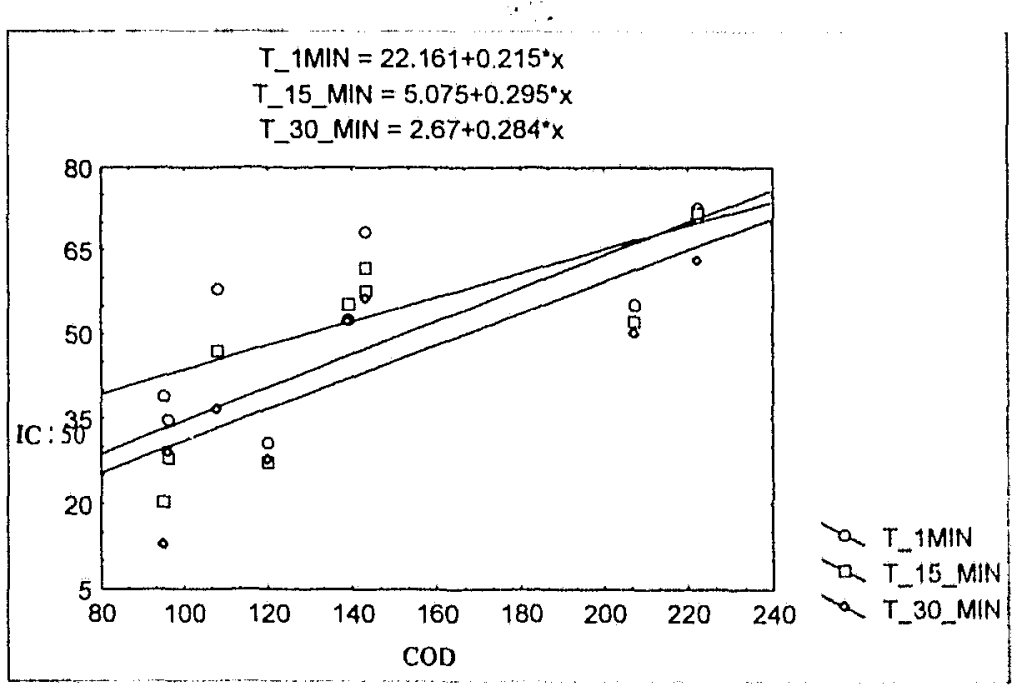

Fig 4.1I(c) COD vs Toxicity values $I_{50}$ at contact imes $T=1,15$ and $30 \mathrm{~min}$ for effluent from stabilization pond 


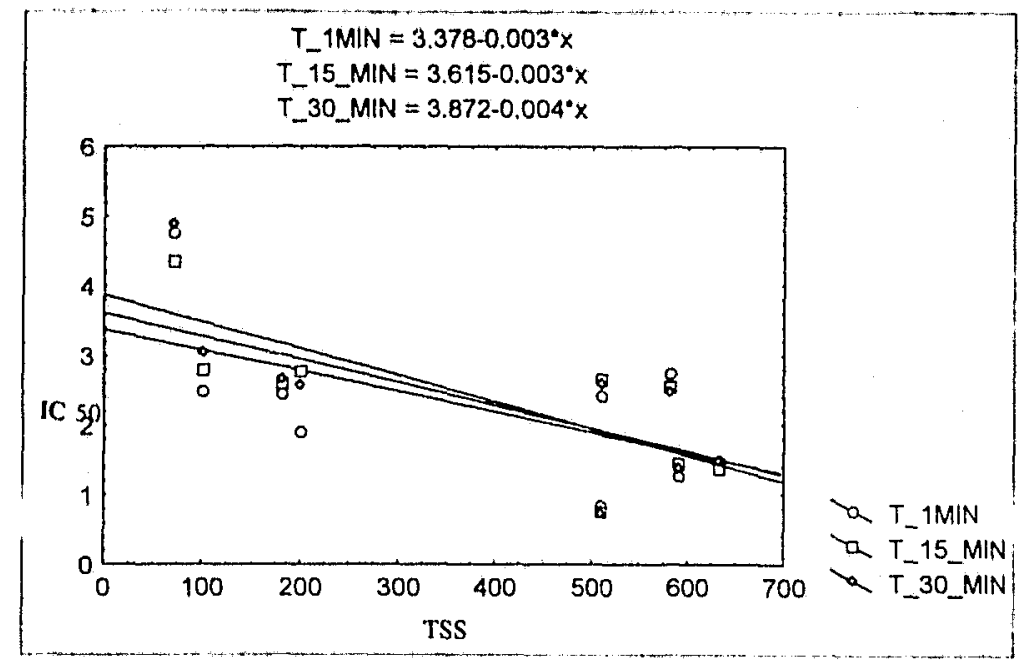

Figure 4.12(a) TSS vs Toxicity concentrations $I_{50}$ at contact times $T=1,15$ and $30 \mathrm{~min}$ for influent to API Separator.

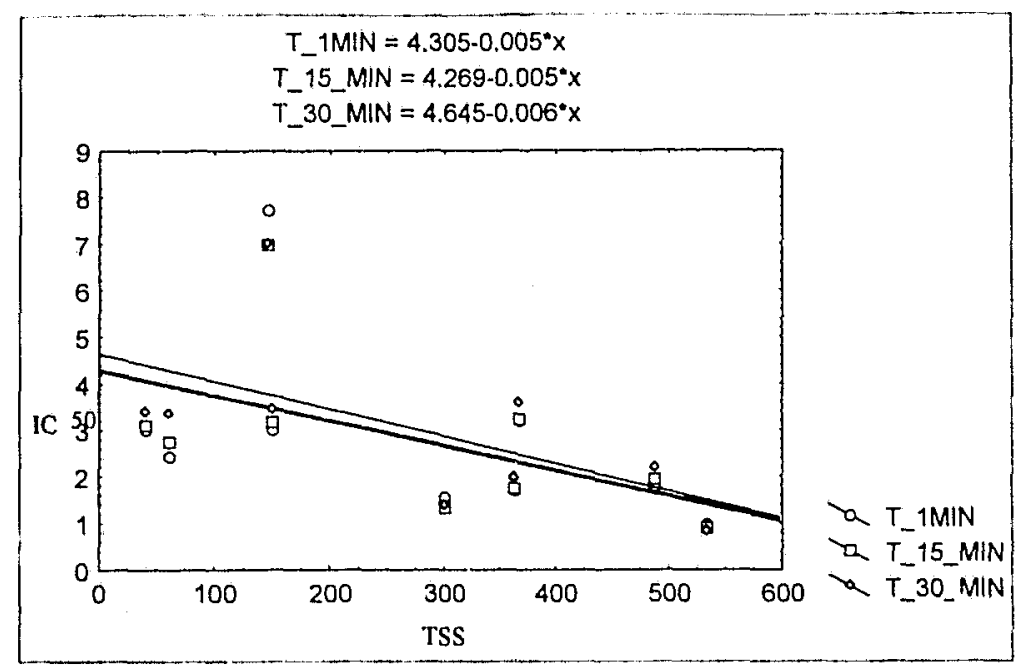

Fig 4.12(b) TSS vs Toxicity concentrations IC $_{50}$ at contact times $T=1,15$ and $30 \mathrm{~min}$ for effluent from API Separator

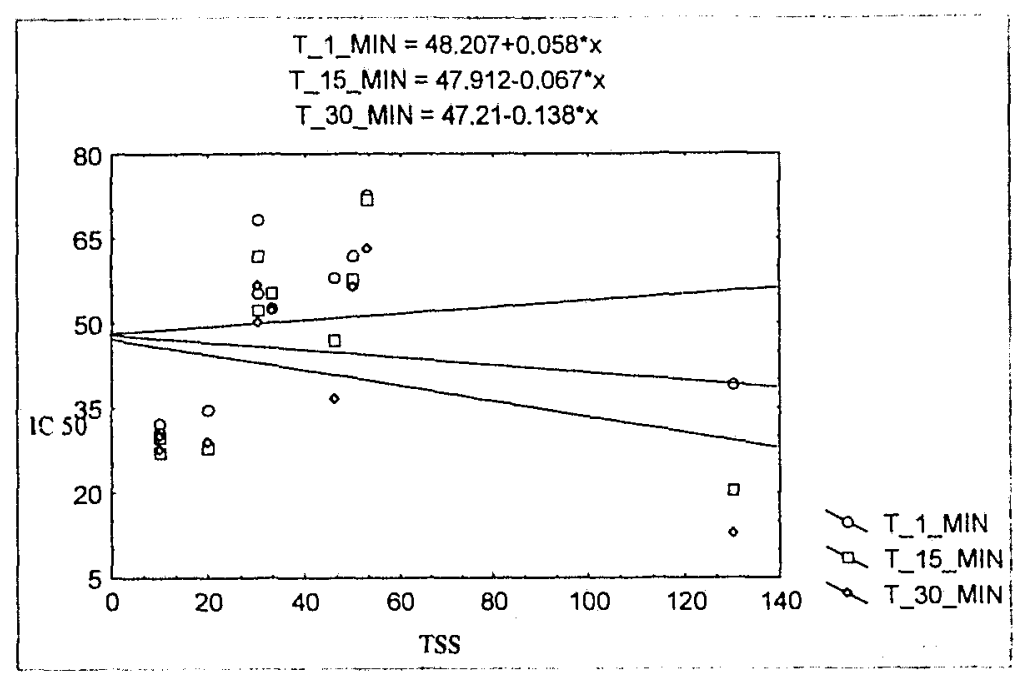

Fig 4.12(c) $T S S$ vs Toxicity values $I_{50}$ at contact times $T=1,15$ and $30 \mathrm{~min}$ for effluent from stabilization pond. 


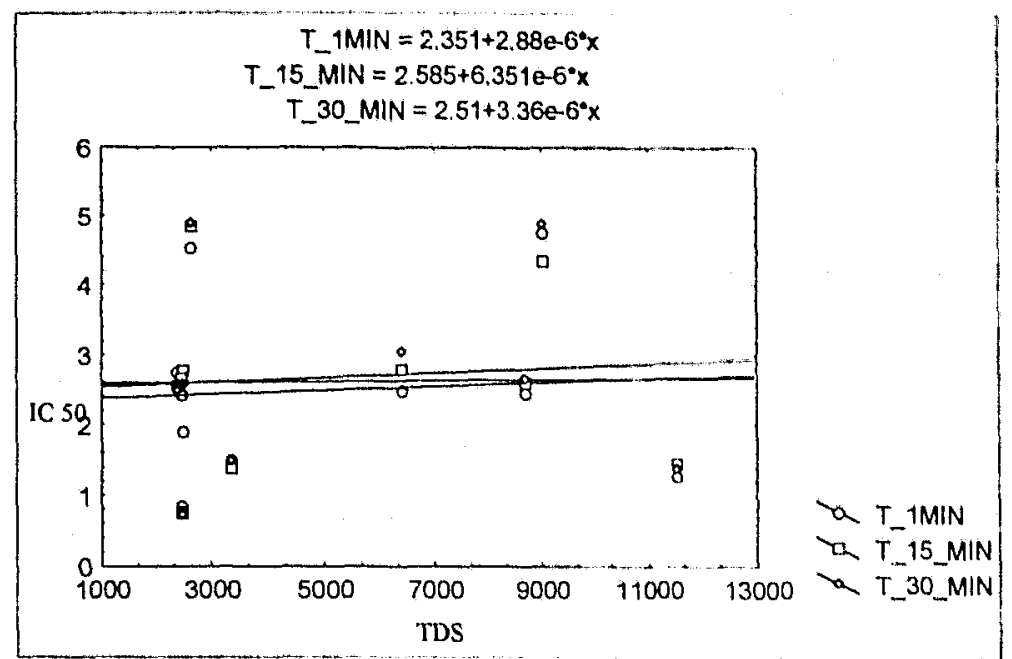

Figure 4.13(a) TDS vs Toxicity values $I_{50}$ at contact times $T \cdots 1,15$ and 30 min for influent to API separator.

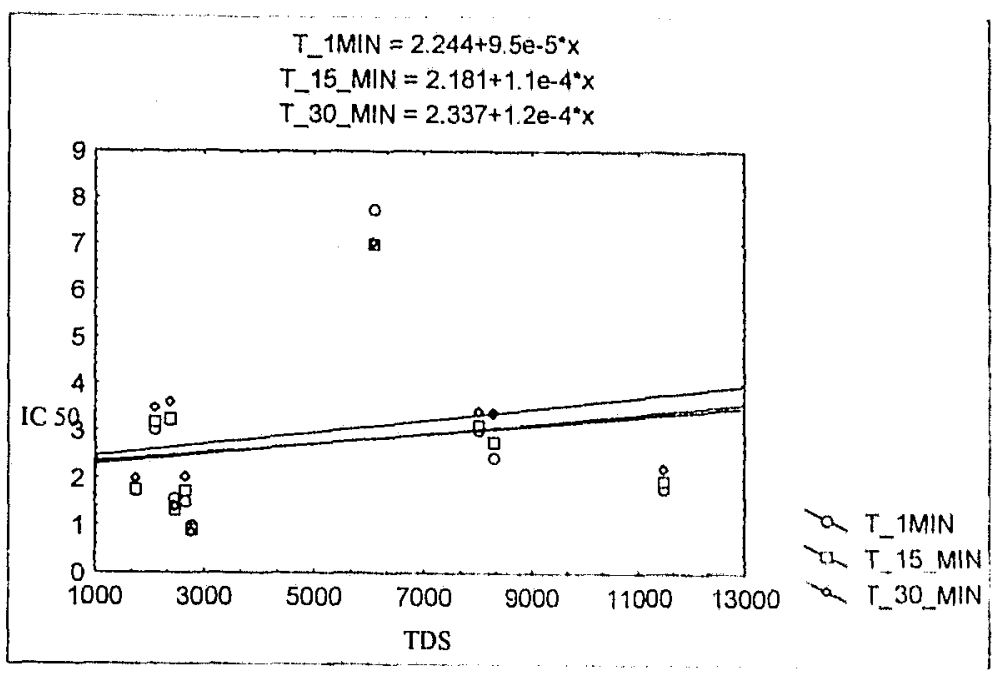

Figure 4.13 (b) TDS vs Toxicity values $I C_{50}$ at comact times $T=1,15$ and 30 min for effluent to API separator.

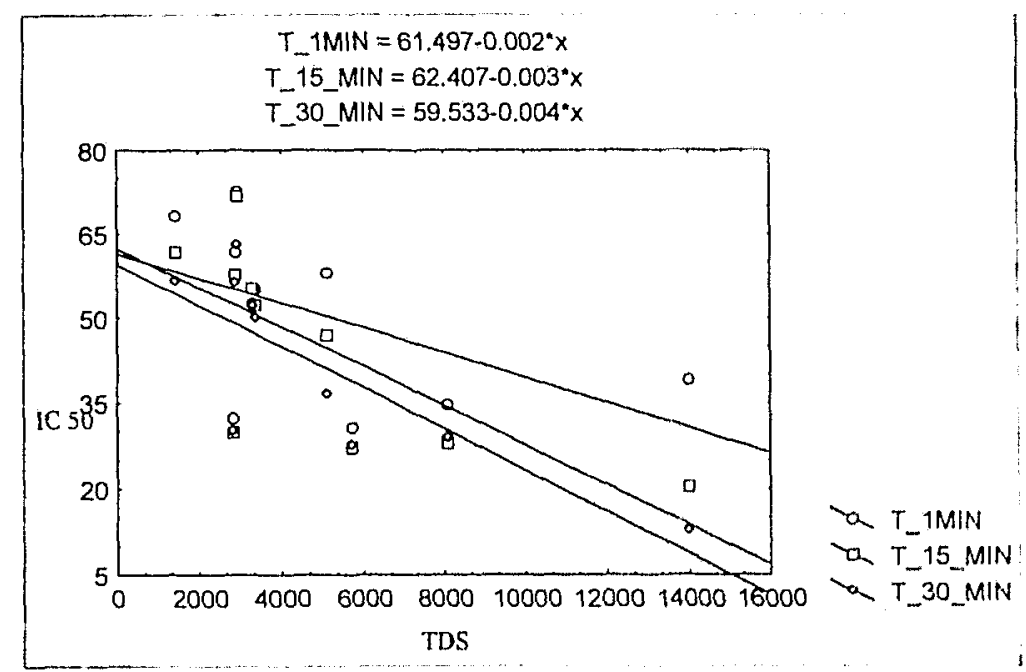

Figure 4.13 (c) TDS vs Toxicity concentrations $I_{50}$ at contact time $T-1,15$ and 30 ) $\mathrm{mm}$ for effluent from stabilization pond 


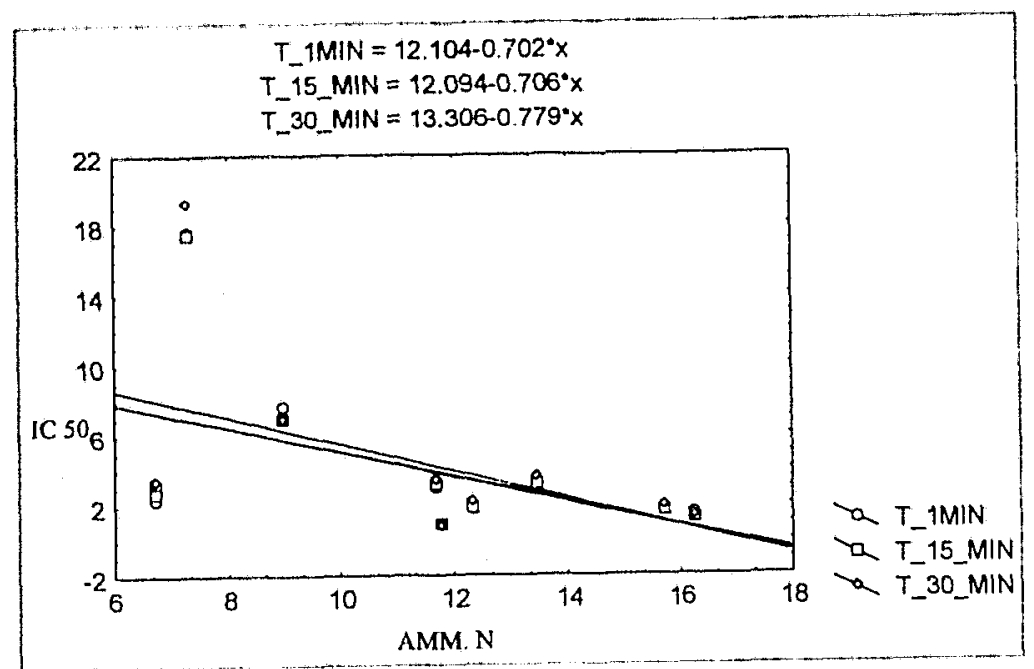

Figure 4.14 (a) $\mathrm{NH}_{3}{ }^{+} \mathrm{N}$ vs Toxicity values $\mathrm{IC}_{50}$ at contact time $\mathrm{T}=1,15$ and $30 \mathrm{~min}$. for effluent from API separator

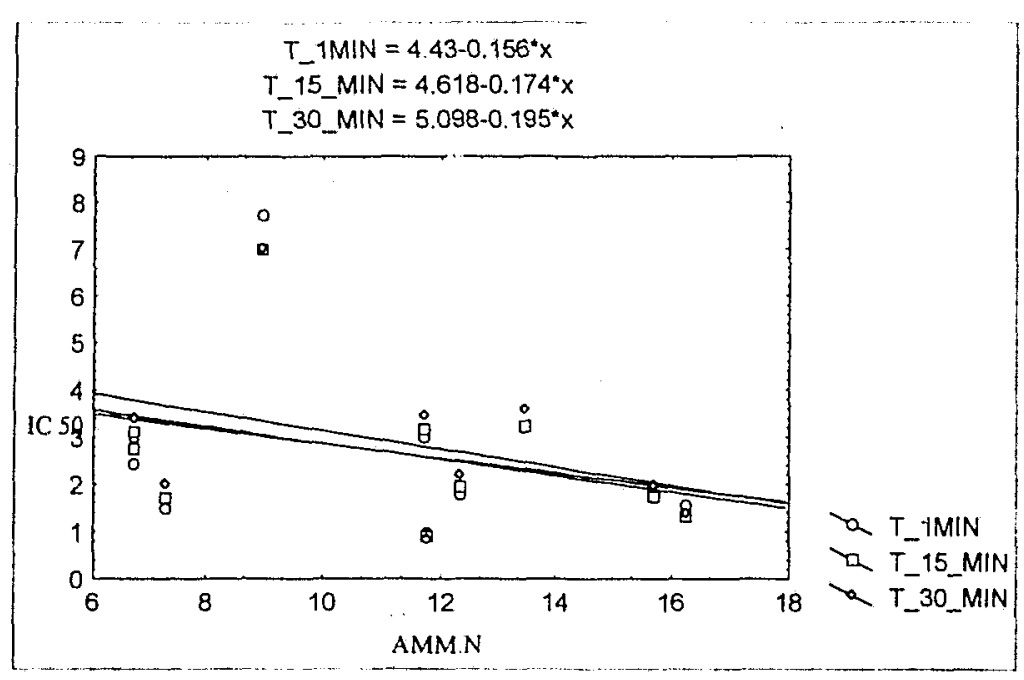

Figure 4.14(b) $\mathrm{NH}_{3}{ }^{+} \mathrm{N}$ vs Toxicity concentration $\mathrm{IC}_{50}$ at contact times $\mathrm{T}=1,15$ and 30 min. for efluent from API separator

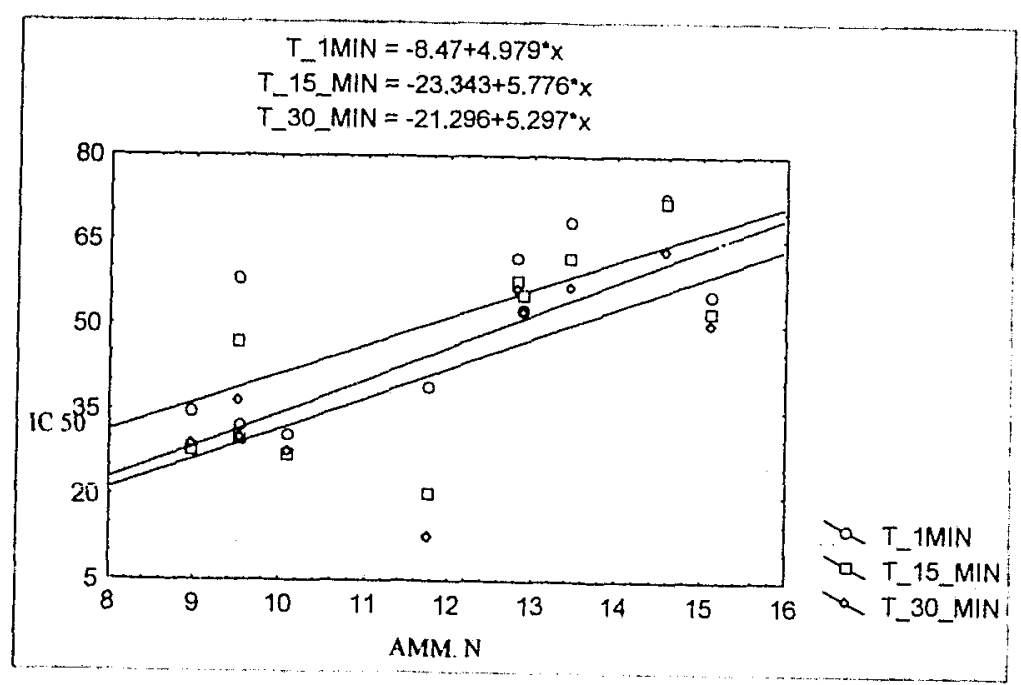

Figure $4.13(\mathrm{c}) \mathrm{NH}_{3}+\mathrm{N}$ vs Toxicity values $\mathrm{IC}_{50}$ at contact time $\mathrm{T}=1,15$ and $30 \mathrm{~min}$, for efluent from stabilization pond. 


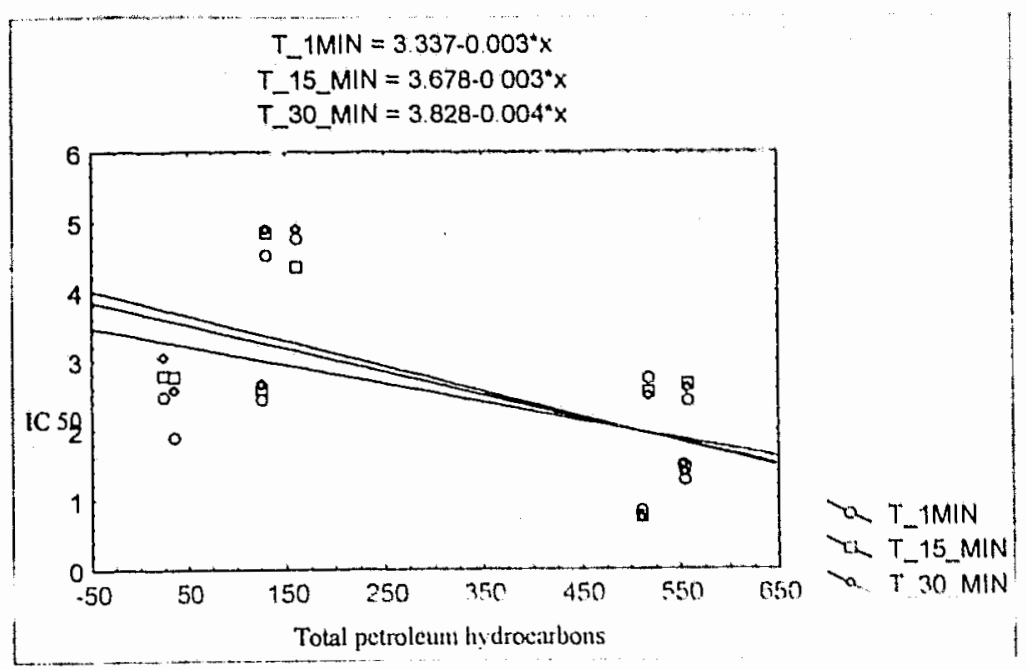

Figure 4.15(a) TPH vs Toxicity concentrations $I C_{s_{0}}$ at contact times $\tau=1,15$ and $30 \mathrm{~min}$ for influent to API separator

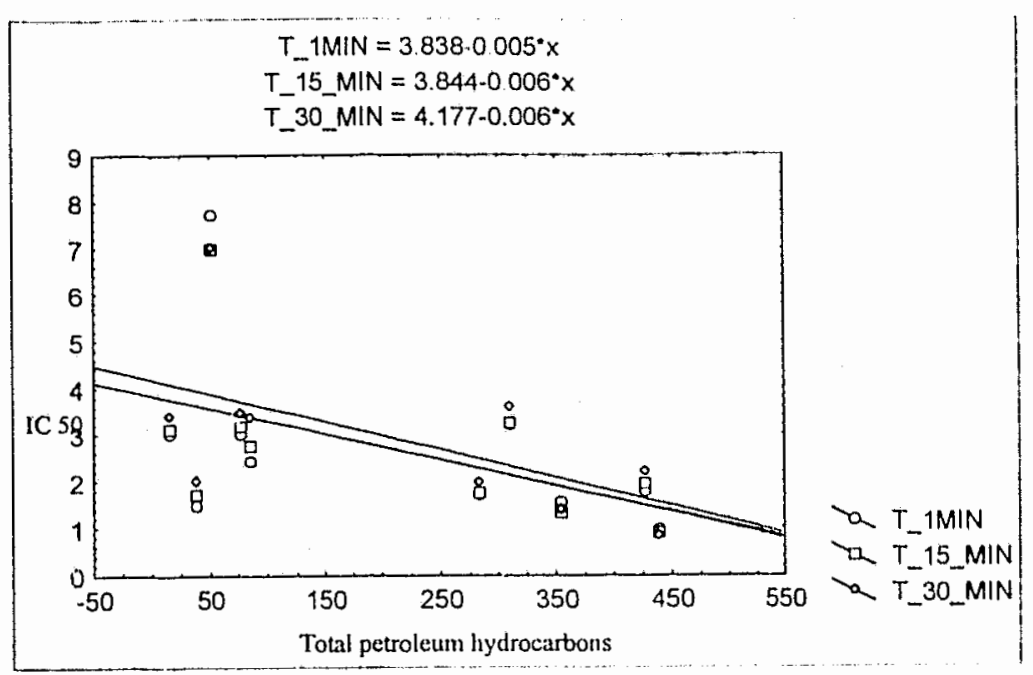

Figure 4.15(b) TPH vs Toxicity concentrations $I C_{50}$ at contact times $T=1,15$ and 30 min for effluent from API separator

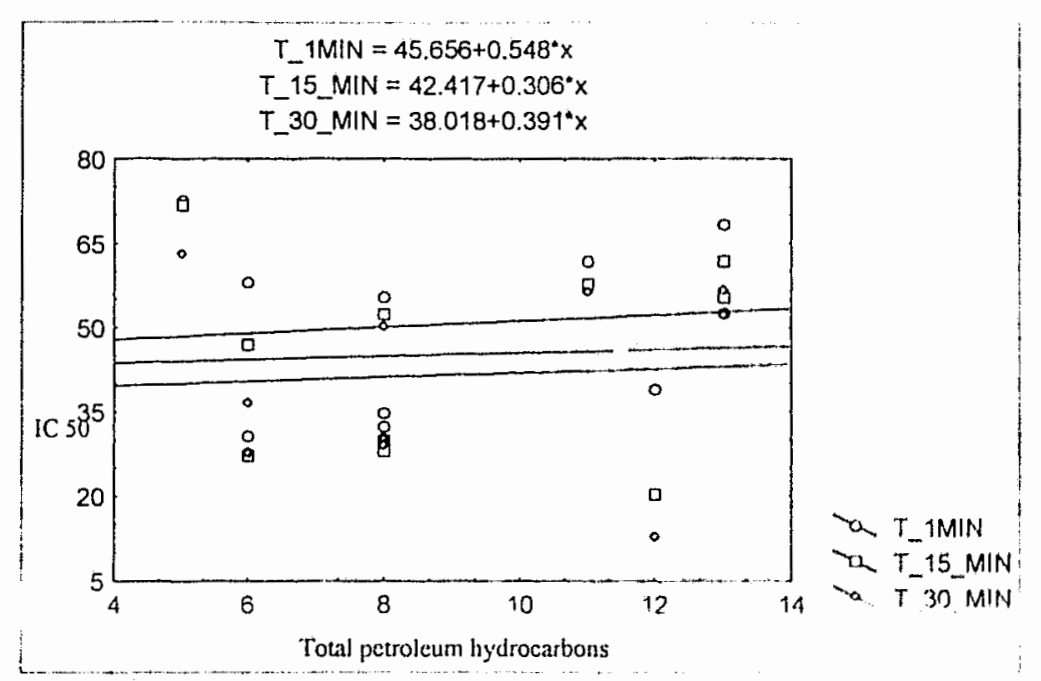

Figure 4.15(c) TPH vs Toxicity concentrations $I_{-50}$ at contact limes $T=1,15$ and $30 \mathrm{~min}$ for effluent from stabilization pond 


\subsection{Discussion on refinery wastewater toxicity}

Generally, the toxicity of influent is expected to be higher than the effluent from the API separator. As it is known, most of the oil is skimmed out by the API separator. A reasonable, if not high, quantity of particulate matter and other substances sorbed into the oil droplets are expected to get removed during this course of action. As mentioned earlier, this was not observed in this study. Therefore the change in toxic patterns could be related to the cumulative effects of waste oil constituents and operational patterns associated with this refinery.

The secondary treated effluent parameters measured in this study were similar to the range of values cited in literature.Different conclusions are drawn with respect to the toxic (acute) nature of effluent from secondary treatment. From an earlier study which included chemical fractionation, Hansen (1989) reported that final effluent toxicity could be attributed to organic constituents. The same could be said of the effluent in the present study too. Statistical evaluation of data from this study indicated a mean toxicity $\left(20\right.$ min $\mathrm{EC}_{50}$ ) of 29 perecnt effluent with a standard deviation of 11.7 percent. A mean toxicity $\left(30\right.$ min $\left.\mathrm{IC}_{50}\right)$ of 40 percent effluent with a standard deviation of 16 percent was observed for final effluent of this study. The reason for this differnce could be the type of sampling- $24 \mathrm{~h}$ composite sampling and number of samples-(34) in the reported study compared to grab sampling and 11 samples in this study. Sherry et al. (1594) observed negative results with Microtox for effluents collected at two different refineries. Even concentrating the effluent at $10 \mathrm{x}$ and 25 $\mathrm{X}$ did not change the negative effect significantly. Armant et al. (1980) observed an inhibition value of $12.4 \pm 1.9$ percent for a secondary refinery effluent in an enzyme bioassay. The characteristics of the effluent in present study were found to be almost identical to that effluent. In spite of the major difference in bioassays, this shows the 
drawbacks of secondary treatment in meeting discharge requirements. In the present study twice $\mathrm{IC}_{50}$ values of $12 \pm$ percentage were observed for samples $5(\mathrm{c})$ and $9(\mathrm{c})$. In one of the samples-5(c), the toxic effects were found to decrease with increase in exposure period. Therefore, it was expected that the effluent quality would improve. The same cannot be said of sample-9(c). Because, the toxicity of this sample seemed to be increasing with time. Incidentally, this sample had the highest concentration of TSS and TDS among all effluent samples. In an earlier study, TSS has not been identified as toxicity contributor of refinery effluent(Armant et al, 1980). Therefore, the possible causative agent in this sample could be TDS.

In all, results of this study attested the fact that Microtox bioassay test could serve as an adequate screening tool for determining the relative toxicities of process and waste treatment streams of the Consumers' COOP Refinery Ltd, Regina.

\subsection{Discussion on statistical analysis of $\mathrm{IC}_{50}$ vs. refinery wastewater parameters}

From the results of statistical analysis it could be seen that there exists a significant relationship between refinery wastewater parameters and their corresponding Microtox $\mathrm{IC}_{50}$ values. Of the six wastewater parameters, one or two exhibited a strong relationship with toxicity values. The remaining parameters which did not bear a relationship were nowhere near the significant statistic value considered in this study. This insignificance could be governed by so many factors such as process patterns, process upsets, effectiveness of wastewater unit operations. A detailed description about the relationship between each of the wastewaters and their corresponding Microtox $\mathrm{IC}_{50}$ values is provided in the following paragraphs.

\subsubsection{Influent to API separator}

Significant relationship between four of the wastewater characteristics and $\mathrm{IC}_{50}$ values were observed. According to the correlation coefficient (r) values, in an increasing order, they are 
arranged as- $\mathrm{TPH}, \mathrm{NH}_{3}{ }^{+} \mathrm{N}, \mathrm{COD}$ and TSS. The last two parameters were found to influence the toxicity values greatly, as seen from their correlation values and significance at all three exposures. Higher values of ' $F$ ' test of these two parameters and their corresponding Figures 4.11(a) and 4.12(a) also support this correlation. Figure 4.11(a) show that there is a strong influence of ' $\mathrm{X}$ ' variable to direct the pattern of corresponding 'Y'-IC 50. It could be seen from the slope of 1,15 and $30 \mathrm{~min}$. plots. Inspite of a very marginal value, the slope depicts two things-severity of bioassay and time dependence of COD and TSS. Inspite of such a high ' $r$ ' (0.801) and ' $F$ ' (14.27) values for TSS from this study, the relationship could raise some doubts due to past records. Although, particulate toxicity has been seen as a major factor in toxicity reduction evaluation (TRE) efforts (Vignon et al,1989) the idea of TSS as an indicator of toxicity has not been suggested anywhere. Because, the inconsistency in processes and bad house keeping could result in a frequent fluctuation in the original concentration. Samples 1(a) and 2(a) could be cited as examples for such conditions. It should also be remembered that, in the refinery under discussion, the sump which receives process wastewaters also occasionally receives storm water.

Ammonia nitrogen is well known as a toxicant. Haywood (1983) reviewed about the effects of ionized and un-ionized ammonia to fishes of diferent sources individually and along with other toxins. Significance of ammonia as a toxicity contributor in wastewater depends mostly on the concentration of un-ionized form. As a synergist, the contribution of ammonia in effluent mixture was significant (Armant et al, 1980). $\mathrm{pH}$ is one of the factors that greatly influences toxicity of ammonia. A rise in $\mathrm{pH}$ increases the concentration of un-ionized form of ammonia.Cote (1976) reported an increase in toxicity of ammonia when $\mathrm{pH}$ rose from 7 to 8. In this study toxic patterns to support such a statement was not observed anywhere. The following example would further clear the doubt, if any. One of the samples- 2(a) collected for this study had a $\mathrm{pH}$ of 7.5. Distinct difference in toxicity values between this 
sample and another sample 1(a) which had lesser $\mathrm{pH}$ and ammonia content were not observed. Influence of ammonia over certain organic compounds like phenols, thus increasing the lethality has been reported (Pessah et al. 1973).Results of the present study at least raises the possibility that ammonia as an individual parameter could be recognised as an indicator of wastewater toxicity.

Total petroleum hydrocarbons which mainly include oil and grease, apart from certain hydrocarbons such as short-chain acids and complex aromatics are known to be lethal substances. Higher concentration of TPH in an effluent would certainly give an idea about the lethality of wastewater, irrespective of any bioassay. A reasonable ' $r$ ' value and a vastly improving ' $\mathrm{F}$ ' value $\left(2.561\right.$ at $1 \mathrm{~min}$. to 5.255 at $\left.15 \mathrm{~min} \mathrm{IC}_{50}\right)$ indicate that the linear relationship is likely to improve further. Therefore, it is possible that TPH could be used as a surrogate of refinery wastewater toxicity, in a regular manner.

\subsubsection{Effluent from API separator.}

The most surprising and intriguing feature of this study is the absence of significant relationship between API effluent parameters and toxicity values $\left(\mathrm{IC}_{50} \mathrm{~s}\right)$. Except for TPH $\left(15 \& 30 \mathrm{~min} . \mathrm{IC}_{50}\right)$, none of the parameters exhibited significant correlation values $(\mathrm{r})$. Therefore any idea of a linear relationship between API effluent parameters and toxicity values are not possible at all. This could be observed from the ' $F$ ' test values too. It is well known that variance influences the ' $F$ ' test.Better the variance (or) the spread of population, more accuracy will be exhibited in the linear relationship between wastewater parameters and toxicity. In most cases, significant difference was not observed from Figures 4.10 (b) to 4.15(b) and slope ( $\beta$ ). Still, this cannot be used to predict the significance between wastewater characteristics and toxicity. For some parameters like oil (TPH), COD and filtered suspended solids a significant percent reduction is expected in a API effluent 
(Environment Canada, 1990). The reported percent reduction with respect to each parameter was achieved only on occasions. If the reported reduction had happened on a regular basis, possibilities of API effluent parameters as surrogates of toxicity would have improved.

\subsubsection{Emuent from stabilization pond}

Significant relationships were found to exist between toxicity and four wastewater parameters for stabilization pond effluent (c). According to the ' $r$ ' values, they are shown in an increasing order-pH, $\mathrm{NH}_{3}{ }^{+} \mathrm{N}, \mathrm{COD}$ and TDS. Among them, the relationship of COD, TDS and $\mathrm{NH}_{3}{ }^{+} \mathrm{N}$ with good correlation values ( $\mathrm{r}$ ) were strong enough to categorize them as surrogate parameters of effluent toxicity. The correlation coefficients ( $r$ ) and ' $F$ ' test values COD and TDS were found to increase proportionally with time, whereas ' $r$ ' value of $\mathrm{NH}_{3}{ }^{+} \mathrm{N}$ remains constant. In the case of TDS, statistical quantities prove beyond doubt, that this parameter could be recognised a surrogate of toxicity. Moreover the time bound improvement shed light to the fact that an increased contact time, as seen in other bioassays would have strengthened this parameter's validity.

In the case of $\mathrm{pH}$, it cannot be identified as a possible surrogate of toxicity. Because, a significant relationship that existed during initial period $(1 \& 15 \mathrm{~min}$.) was not observed with increase in time $(30 \mathrm{~min}$.). Toxicity was found to increase with increase in time as observed from Figure $4.10(\mathrm{c})$. Sometimes, toxicity also used to increase greatly with a decrease in $\mathrm{pH}$ (Cote, 196). Therefore, the pattern observed for the effluent in this study, cannot be expected to happen in similar type of effluents. Also, $\mathrm{pH}$ doesnot exactly reflect the toxic nature of effluent. This can be seen from the toxic behaviour of effluents collected at two different periods, which exhibited same $\mathrm{pH}$. Sample 2(c) produced an $\mathrm{IC}_{50}$ of 36.61 percent, whereas 9(c) inhibited Microtox assay at an effluent concentration of 12.83 
percent. Such a difference was observed at 30 min exposure period.A parameter which produces such a wide difference in toxic pattern cannot be identified as a surrogate.

USEPA established a unionized ammonia level of $0.020 \mathrm{mg} / \mathrm{l}$ in 1976 . In 1985 , it was modified to $0.030 \mathrm{mg} / \mathrm{l}$ except for special use zones which protect sensitive species. "Canadian Water Quality Guidelines", reference the EPA's guideline and use similar toxicity data.Ammonia nitrogen concentration observed in this effluent throughout this study far exceeded this water quality criterion. Surprisingly, more than $50 \%$ of stabilization pond effluent $\mathrm{IC}_{50} \mathrm{~s}$ measured in this study did not seem to reficit the lethality of ammonia. Despite this, the ammonia concentrations of effluent along with reasonable statistical values indicate that ammonia nitrogen could be identified as a toxicity surrogate.Apart from $\mathrm{pH}$, factors such as temperature too greatly enhances the concentration of un-ionized ammonia. Therefore, toxicity of this effluent due to ammonia is likely to be more during the summer months.

TSS did not qualify as a surrogate of toxicity, in this study. It did not seem to be a surprise, as Hansen(1989) observed a correlation coefficient of -0.31 between TSS and final effluent toxicity with fish studies. Therefore, of the four parameters that exhibited a significant statistical relationship, only TDS and COD could be considered as surrogates of effluent toxicity.

It is acknowledged that the results of present study could be improved with more number of samples. In spite of the numbers, this study helped to strengthen the concept of whole effluent toxicity testing (WET). 


\section{CHAPTER 5}

\section{SUMMARY, CONCLUSIONS AND FURTHER RESEARCH NEEDS}

\subsection{Summary}

Toxicity studies using Microtox bioassay were conducted to evaluate the toxic potential of three different types of refinery wastewaters. Observed toxic values were statistically compared with characteristics of the wastewater. Some of the wastewater parameters were found to exhibit a linear relationship with toxicity. From the data, the effectiveness of certain processes in toxicity reduction was also examined.

\subsection{CONCLUSIONS}

From the present study, the following conclusions are drawn:

- Wastewaters associated with API separator (influent and effluent) were found to be toxic;

- More than one-third of effluent samples from stabilization pond were found to be toxic 1(c), 3(c), 5(c) and 9(c). A consistency in toxicity reduction was not noticed; - Influence of API separator in toxicity reduction was observed only in a few samples; 
- In this study wastewater parameters such as COD, TDS and TSS exhibited a significant relationship with toxicity. Therefore they could be identified as surrogates of toxicity;and - Microtox assay has proved to be an excellent screening tool for the evaluation of toxicity of wastewaters related with refinery.

\subsection{FURTHER RESEARCH NEEDS}

Following studies should be designed and conducted in future.

- Increasing the monitoring period to improve the confidence in the results of present study;

- simultaneous conduct of fish or any recommended bioassay studies to identify or establish a relationship, if there is any;

- source investigation from the existing process streams to identify the proximal and ultimate sources of final effluent toxicity;

- performance analysis of the existing wastewater treatment plant, to improve the effectiveness of unit operations, especially the API separator;

- bench-top treatment studies to improve the quality of final effluent; and

- increasing the incubation temperature and use of different substances such as sucrose as an alternate to $\mathrm{NaCl}$ in Microtox analyzer to identify sensitivity . 


\section{References}

Alleman, J.E.(1986) "Respiration-Based evaluation of nitrification inhibition using enriched nitrosomonas cultures", Proceedings of International Conference on Innovative Biological Treatment of Toxic Wastewaters, Arlington, Va., 643-651.

Ankley, G.T., Peterson, G.S., Amato, J.R., and Jenson, J.J.(1990). "Evaluation of sucrose as an alternative to sodium chloride in the microtox assay :Comparison to fish and cladoceran tests with freshwater effluents", Environmental Toxicology and Chemistry, 9, 1305-1310.

Arbuckle, W.B., and Alleman, J.E.(1992) "Effluent toxicity testing using nitrifiers and Microtox TM", Water Environment rerearch, 64(3), 263-267.

Alsop, G.M et al(1980) "Bacterial growth inhibition test", Journal Water Pollution Control Federation, 52, 2452.

Armant, D.R., Buikema, A.L., Rutherford, C.L., and Cairns, J.Jr. (1980) "Evaluation of invitro enzyme inhibition for screening petroleum effluents", Bulletin of Environment Contamination and Toxicology, 24, 244-250.

Backman, C.J., and Firth, B.K.(1990) "Comparison of Microtox testing with rainbow trout(acute) and Ceriodaphnia (chronic) bioassays in mill wastewaters",Tappi Journal, December, 169-174.

Blum, D.J.W., and Speece, R.E.(1991) " A database of chemical toxicity to environmental bacteria and its use in interspecies comparisons and correlations", Journal Water Pollution Control Federation, 63(3), 198-207.

Bringmann, G., and Kuhn, R.(1980) "Comparisons of the toxicity thresholds of water pollutants to bacteria, algae and protozoan in the cell multiplication inhibition tests", Water Research, 14(2), 231-241. 
Buikema, A.L., Lee, D.R., and Cairns, J.Jr.(1976) "A screening bioassay using Daphnia pulex for refinery wastes discharged into fresh water", Journal of Test Evaluation, 4, 119125.

Bulich, A.A.(1979) " Use of luminescent bacteria for determining toxicity in aquatic environments"In Aquatic Toxicology: Second Conference, ASTM special technical publication (Eds) Markings, L.L and Kimerle, R.A, 98-106.

Bulich, A.A.(1986) "Bioluminescence Assays", In Toxicity Testing Using Microorganisms. Vol.1, Bitton, G and Dutka, B.J(Eds.)CRC Press Inc, Boca Raton, Fla, 57-74.

Cairns , J.Jr., Dickson, K.L., and Westlake, G.F.(1976) "Biological monitoring of water and effluent quality", Arnerican Society for Testing and Materials, ASTM 607, Philadelphia, PA. Canada Department of the Environment. (1972) "Guidelines for the pulp and paper mill effluent regulations :Regulations, codes and protocols. Report 2.Canada Department of Environment, Ottawa.

Clemens, H.P., and Summers, P.(1953) "Will refinery wastes kill fish?", Petroleum Refinery, 38, 145-147.

Chapman, D.T., and Grammas, J.(1989) "Management and analysis of data from petroleum refinery wastewater treatment plants", Water Pollution Research Journal of Canada, 24(3), $391-410$.

Cote, R.P.(1976) "The effects of petroleum refinery liquid wastes on aquatic life with special emphasis on the canadian environment" NRC Associate Committee on Scientific Criteria for Environmental Quality, Ottawa, Ontario.

Curtis,C., Lima, A., Lozano, S.J., and Veith, G.D.(1982) "Evaluation of a bacterial bioluminescence bioassay as a method for predicting acute toxicity of organic chemicals to fish", in Aquatic Toxicology and Hazard Assessment, ASTM special technical publication 766, (Eds) Pearson, J.G., Foster, R.B ., and Bishop, W.E, 170-178. 
Das, P.K.M.K and Konar, S.K.(1988) " Acute toxicity of petroleum products, crude oil and oil refinery effluent on plankton, benthic invertebrates and fish", Environment and Ecology, 6(4), 885-891.

Dold, P.L.(1989) "Current practice for treatment of petroleum refinery wastewater and toxics removal", Water Pollution Research Journal of Canada, 24(3), 363-390.

Douglas, N.H., and Irwin, W.H.(1963) "Relative resistance of fish species to petroleum refinery wastes: Parts I and III", Water and Sewage Works, R246-250, R258-261.

Dowdy,S.,and Wearden, S.(1985) "Statistics for research", Second Edition,Wiley Interscience, NewYork, N.Y, 10158-0012.

Dutka, B.J., and Kwan, K.K.(1983) "Studies on a synthetic activated sludge toxicity screening procedure with comparison to three microbial toxicity tests", In Toxicity Screening Procedures using Bacterial systems, Toxicity Series, Vol.1, Marcel Dekker Inc, New York, N.Y, 125-138

Graham, R.J., and Dorris, T.C.(1968) " Long term toxicity bioassay of oil refinery effluents", Water Research, 2, 643-663.

Hansen,S.(1989) "Case history:Tosco corporation's Avon refinery,Martinez, California" In Generalized Methodology for Conducting Industrial Toxicity Reduction Evaluations (TREs), EPA/600/2-88/070 USEPA, April 1989.

Hart, W.B., Doudoroff, P., and Greenbank, J.(1945) " The evaluation of the toxicity of industrial wastes, chemicals and other substances to fresh- water fishes", Atlantic Refining Co., Philadelphia, PA.

Haywood, G.P.(1983)" Ammonia toxicity in teleost fishes:a review" Technical Report No.1177.Dept of Fisheries and Oceans, Nanaimo, British Columbia.

Huber, L., Baumung, H., Metzner,G., and Popp,W.(1979) "Part IV: Ecological effects of refinery effluents in fresh water with particular reference to substances on list 1 of the EEC guidelines for water protection" In The Environmental Impact of Refinery Effluents, CONCAW, Report no. 5/79. 
Indorato, A.M., Snyder, K.B., and Usinowicz, P.J.(1984) "Toxicity screening using micritox analyser", In Toxicity Screening Procedures Using Bacterial Systems, Toxicity Series, Vol.1, Marcel Dekker Inc, New York, N.Y, 37-53.

Klecka, G.M., and Landi, L.D(1985) "Evaluation of the OECD activated sludge respiration inhibition test", Chemosphere, 14(9), 1239-1246.

Konar, S.K., and Panigrahi, A.K(1992) "Influence of petroleum refinery effluent in presence of non-ionic detergent sandozin NIS on fish", Environment \& Ecology, 10(1), 55-59.

Larson, R.J., and Schaeffer, S.L.(1982) "A rapid method for determining the toxicity of chemicals to activated sludge", Water Research, 16(5), 675-680.

Matthews, J.E., and Myers, L.H.(1976) "Acute toxic effects of petroleum refinery wastewaters on redear sunfish", EPA-600/2-76-241. US.Environmental Protection Agency, Ada, OK.

Maynard, A.W.(1989) "Chemical Monitoring: Effective use of chemical analysis for optimisation of contaminant removal", Water Pollution Research Journal of Canada, 24(3), 411-424.

Microbics Corp.(1992) "How to run a standard Microtox test" Vol-3, Microbics, Carlsbad, CA.

Nikunen, E.(1985) "Toxic impact of effluents from petrochemical industry", Ecotoxicology and Environmental Safety, 9, 84-91.

Organization of European Community Development.(1987) " Method 209, Activated sludge, Respiration inhibition test, OECD Guidelines for Testing of Chemicals, OECD, Paris, Fr.

PACE.(1985a) "Evaluation of the variability of trace organic substance in petroleum refinery effluents", The Petroleum Association for Conservation of the Canadian Environment. Report 85-6 Ottawa, Ontario. 
Pessah, E., Loch, J.S., and MacLeod, J.C. (1973) "Preliminary report on the acute toxicity of petroleum refinery effluents to fish", Technical Report No.408, Fisheries Research Board of Canada, Winnipeg, Canada.

Pessah, E., and Cornwall, G.M. (1980) "Use of toxicity tests in regulating the quality of industrial wastes in Canada", Aquatic Toxicology, ASTM special technical publication 707, 130-141.

Qureshi, A.A., Flood, K.W., Thompson, S.R., Janhurst, S.M., Inniss, C.S., and Rokosh, D.A.(1982) "Comparison of a luminescent bacterial test with other bioassays for determining toxicity of pure compounds and complex effluents", ASTM special ievinnical publication 766, 179-195.

Rice, S.D., Short, J.W., and Karinen, J.F.(1976) "Comparitive oil toxicity and comparitive animal sensitivity", Fate and Effects of Petroleum Hydrocarbons in Marine Ecosystems and Organisms (Ed) Wolfe, D.A. Pergamon Press, New York, N.Y.78-91.

Rebhun, M., and Galil, N.(1987) "Biotreatment inhibition by hazardous compounds in an integrated oil refinery", Proceedings of 42nd Purdue Industrial Waste Conference, Lewis Publishers, AnnArbor, Michigan, MI. 143-150.

Sherry, J.P., Scott, B.F., Nagy, E and Dutka, B.J.(1994) " Investigation of the sublethal effects of some petroleum refinery effluents", Journal of Aquatic Ecosystem Health, 3, 129137.

Sprague, J.B., Rowe, D.W., Westlake, G.F., Heming, T.A and Brown, I.T.(1978) "Sublethal effects of treated liquid refinery effluent from a petroleum refinery on freshwater organisms", Petroleum Association for Conservation of the Canadian Environment, and Fisheries and Environment Canada, Ottawa, Ontario.

Stumm,W and Morgan, J.J.(1981) "Aquatic Chemistry: An introduction emphasizing chemical equilibria in natural waters", Ed. 2nd, Wiley-Intersicence, Inc. 
USEPA.(1976) "Quality criteria for water" Office of Research and Deveopment, Office of water, Washington DC.

Vasseur, P., Fernard, J.F., Rast, C., and Lurbaigt, G.(1984) " Luminescent marine bacteria in ecotoxicty screening tests of complex effluents"In Toxicity Screening Procedures using Bacterial systems, Toxicity Series, Vol,1, Marcel Dekker Inc, New York, N.Y, 37-54.

Vignon, B.W., Cooney, J.D., and Clement, W.H.(1989) "Engineering for toxicity removal: A new set of design rules" Proceedings of 44th Purdue Industrial Waste Conference, Health Environmental Center-Battelle, Columbus, Ohio, OH. 97-104.

Walden, C.C(1976) " The toxicity of pulp and paper mill effluents and corresponding measurement procedures", Water Research, 10, 639-664.

Wall, T.M., and Hanmer, R.W.(1987) "Biological testing to control toxic water polutants", Journal Water Pollution Control Federation, 59,7-12.

Weber, C.I. (1989) "Short -Term methods for estimating the chreonic toxicity of efluents abnd receiving waters to freshwater organisms",USEPA/600/4-89/001, USEPA, Washington,D.C.

Wolaver, H., Spence, S., and Paton, I(1993)."Application of two real-time toxicity tests to monitor rocky flats plant water quality" Proceedings of 48th Purdue Industrial Waste Conference, Lewis Publishers, AnnArbor, Michigan, MI , 285-294. 
FILE NAME: 950427B1.K1

TEST DATE:

TEST TIME:

Investigator:

Approved by:

Sample Description: COOP Ref., Inf. to API Sep., pH=adj.

Procedure: BASIC

Initial Concentration : $4.5 \&$

Test Time: 1 minutes

NUMBER

IO/IT CONC.

Osmotic Adjustment: MOAS

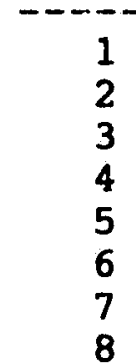

$89.78 / 61.22$
$90.18 / 61.57$
$90.33 / 47.25$
$86.44 /$
$86.70 / 25$
$88.04 / 31.43$
$88.58 / 22.06$
$89.14 / 21.32$

CONTROL IT/IO $=$

RATIOS =

$83 . \angle 2 / 92.20$

CORRECTION FACTOR $=0.9004$

0.5625

0.5625

1.1250

1. 1250

2.2500

2.2500

4.5000

4.5000

$82.51 / 91.87 * *$

$0.8981 * \star$
Dilution Factor : 2

Concentration Units: \&

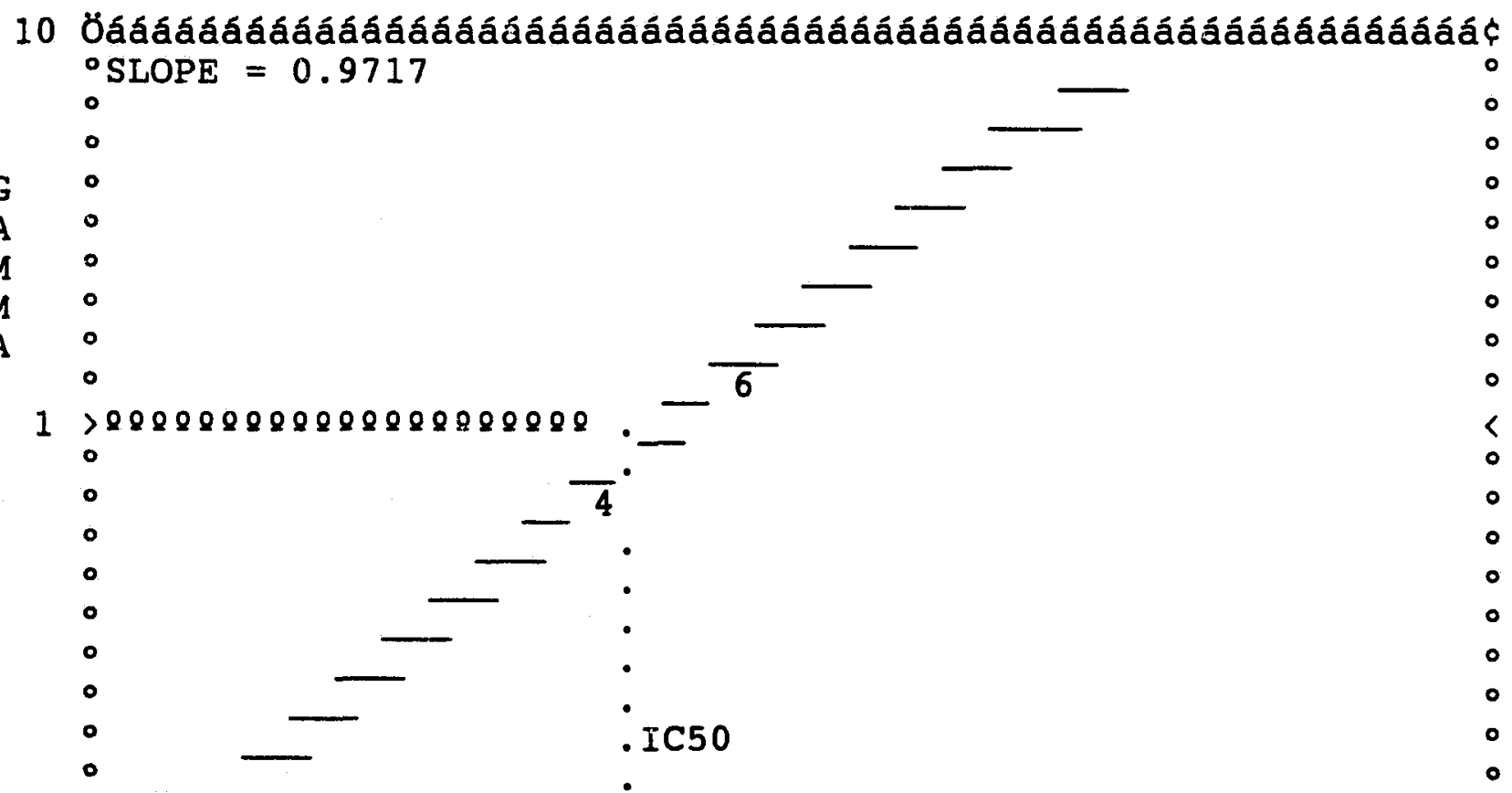

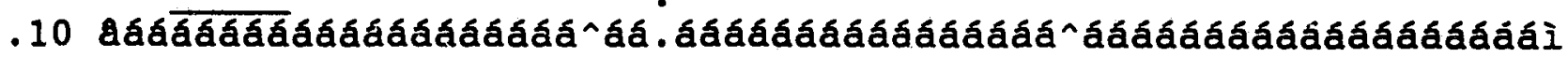
.100

1 CONCENTRATION

10

IC50 1.4946 (958 CONFIDENCE RANGE: 1.4405 TO 1.5506 )

* Used for calculations 
ESTIMATING EQUATION: LOG C $=1.0290 \times$ LOG $\tilde{a}+0.1745$

NUMBER OF DATA PAIRS USED: 3

RESIDUAL VARIANCE: 0.00000

958 CONFIDENCE FACTOR: 1.03753 FOR IC50

CORRELATION COEFFICIENT: $R=0.99997$

COEFFICIENT OF DETERMINATION: $R^{\wedge} 2=0.99994$

INHIBITING CONCENTRATIONS (958 CONFIDENCE RANGE):

\begin{tabular}{|c|c|c|c|c|c|c|}
\hline $\begin{array}{l}50= \\
20= \\
10=\end{array}$ & $\begin{array}{l}1.4946 \\
0.3589 \\
0.1558 \\
0.0132\end{array}$ & $\begin{array}{l}8 \\
8 \\
8 \\
8\end{array}$ & ? & $\begin{array}{l}1.4405 \\
0.3052 \\
0.1221 \\
0.0081\end{array}$ & $\begin{array}{l}\text { TO } \\
\text { TO } \\
\text { TO } \\
\text { TO }\end{array}$ & $\begin{array}{l}1.5506) \\
0.4221) * \star \star \\
0.1988) * \star \star \\
0.0215) * \star *\end{array}$ \\
\hline
\end{tabular}

*** EXTRAPOLATE RESULTS 
FILE NAME: 950427B1.K15

Investigator:

Sample Description: COOP Ref., Inf. to API Sep., pH=adj. Procedure: BASIC

Initial Concentration : 4.58

Test Time: 15 minutes NUMBER

--
1
2
3
4
5
6
7
8

I0/IT

$$
\begin{aligned}
& 89.78 / 60.06 \\
& 90.18 / 61.45 \\
& 90.33 / 45.22 \\
& 86.44 / 42.73 \\
& 86.70 / 27.00 \\
& 88.04 / 27.88 \\
& 88.58 / 16.39 \\
& 89.14 / 15.63
\end{aligned}
$$

CONTROL IT/IO =

$\begin{array}{ll}0.5625 & 0.32205 \\ 0.5625 & 0.29790 \\ 1.1250 & 0.76666 \# \\ 1.1250 & 0.76910 \# \\ 2.2500 & 1.83993 \# \\ 2.2500 & 1.79280 \# \\ 4.5000 & 3.77980 \\ 4.5000 & 4.04390\end{array}$

$80.72 / 92.20$

RATIOS =
CONC.

TEST DATE:

TEST TIME

Approved by:

Osmotic Adjustment: MOAS Dilution Factor : 2 Concentration Units: 8 GAMMA

CORRECTION FACTOR $=0.8844$

$82.07 / 91.87$ **

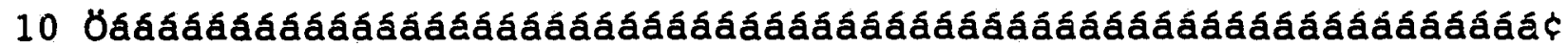
${ }^{\circ} \mathrm{SLOPE}=1.2235$

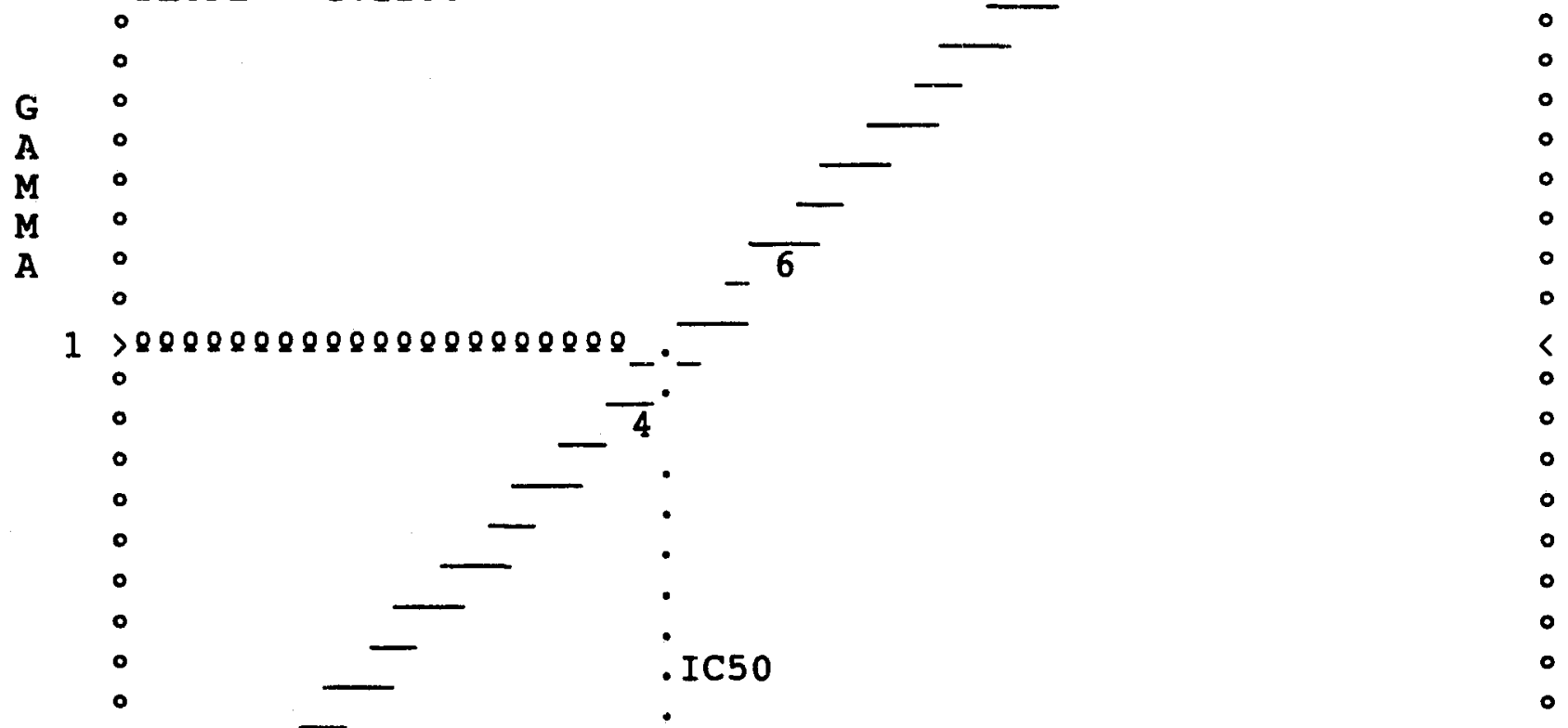

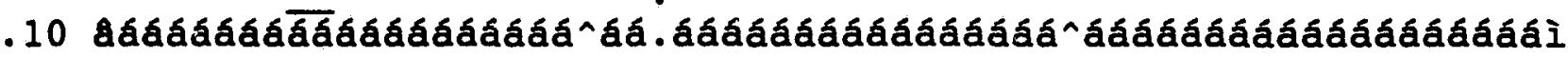
.100

1 CONCENTRATION 10

IC50 1.3817 (95\% CONFIDENCE RANGE: 1.3318 TO 1.4335 ) 
STATISTICAL REPORT FOR DATA FILE 950427B1.K15

ESTIMATING EQUATION: LOG $\mathrm{C}=0.8165 \times$ LOG $\mathrm{a}+0.1404$ NUMBER OF DATA PAIRS USED: 4

RESIDUAL VARIANCE: 0.00005

958 CONFIDENCE FACTOR: 1.03750 FOR IC50

CORRELATION COEFFICIENT: $R=0.99948$

COEFFICIENT OF DETERMINATION: $R^{\wedge} 2=0.99895$

INHIBITING CONCENTRATIONS ( 958 CONFIDENCE RANGE):

$$
\begin{aligned}
& \text { IC50 }=1.3817 \%(1.3318 \mathrm{TO} 1.4335) \\
& \text { IC20 }=0.44558 \quad(0.3912 \text { TO } 0.5073) * \star * \\
& \text { IC10 }=0.2298 \text { \& } \quad(0.1893 \text { TO } 0.2788) * \star \star \\
& \text { ICO1 }=0.03248 \quad(0.0221 \text { TO } 0.0476) * \star *
\end{aligned}
$$


TEST DATE : TEST TIME: Approved by:

Investigator: Sample Description: COOP Ref., Inf. to API Sep., pH=adj. Procedure: BASIC Initial Concentration : 4.5 \& Test Time: 30 minutes NUMBER \begin{tabular}{c} 
IO/IT \\
\hdashline $89.78 / 63.05$ \\
$90.18 / 63.79$ \\
$90.33 / 47.62$ \\
$86.44 / 45.94$ \\
$86.70 / 28.77$ \\
$88.04 / 29.94$ \\
$88.58 / 16.07$ \\
$89.14 / 15.57$ \\
$82.19 / 92.20$
\end{tabular}

--
1
2
3
4
5
6
7
8

CONTROL IT/IO = RATIOS = $82.19 / 92.20$ CORRECTION FACTOR $=0.9050$
Osmotic Adjustment: MOAS Dilution Factor : 2 Concentration Units: 8 CONC.

0.5625
0.5625
1.1250
1.1250
2.2500
2.2500
4.5000
4.5000
$39 / 91.87 \star \star$
$0.9186 \star \star$

$84.39 / 91.87 * \star$
$0.9186 * \star$
GAMMA

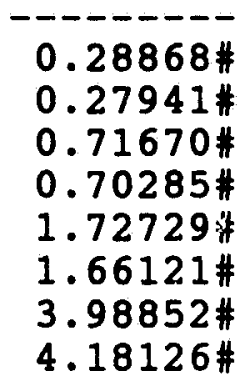

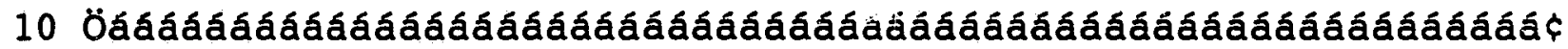
${ }^{\circ} \mathrm{SLOPE}=1.2793$

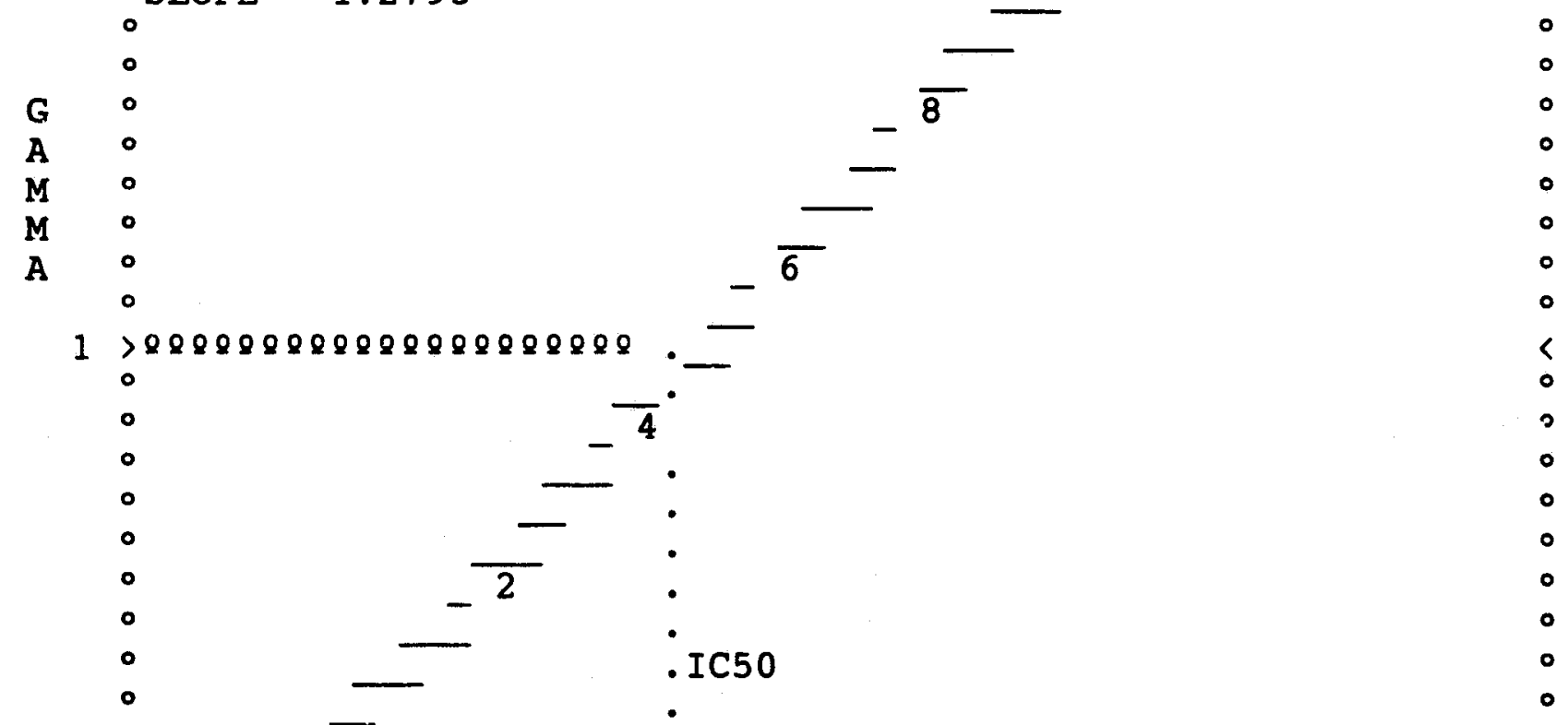

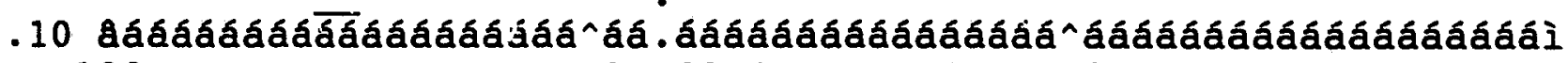
.100

1 CONCENTRATION 10

IC50 1.4910 (958 CONFIDENCE RANGE: 1.4665 TO 1.5158$)$ 
ESTIMATING EQUATION: LOG $\mathrm{C}=0.7813 \times$ LOG $\approx+0.1735$

NUMBER OF DATA PAIRS USED: 8

RESIDUAL VARIANCE: 0.00007

95\% CONFIDENCE FACTOR: 1.01666 FOR IC50

CORRELATION COEFFICIENT: $R=0.99977$

COEFFICIENT OF DETERMINATION: $R^{\wedge} 2=0.99955$

INHIBITING CONCENTRATIONS ( 958 CONFIDENCE RANGE):

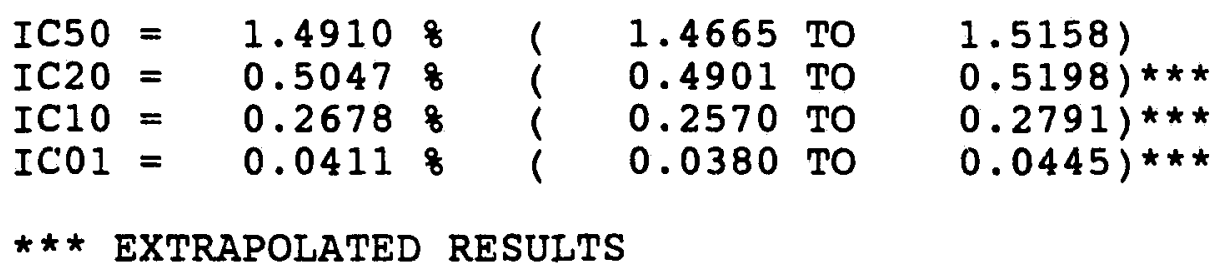


FILE NAME： 950427A1.K1

Investigator:

Sample Description: COOP Ref.,Effl. from Procedure: BASIC

Initial Concentration : 4.58

Test Time: 1 minutes NUMBER

1
2
3
4
5
6
7
8

CONTROL IT/IO = RATIOS $=0.9062$ $97.66 / 65.01$ $96.29 / 62.48$ $94.93 / 52.53$ $92.83 / 50.62$ $91.97 / 32.60$ $91.63 / 31.48$ $93.70 / 21.62$ $95.02 / 23.42$ CORRECTION FACTOR $=0.9060$ CONC.

TEST DATE:

TEST TIME:

Approved by:

API Sep., pH=adj.

Osmotic Adjustment: MOAS

Dilution Factor : 2 Concentration Units: 8

$\begin{array}{cc}-0.5625 & 0.36099 \\ 0.5625 & 0.39623 \\ 1.1250 & 0.63724 \# \\ 1.1250 & 0.66143 \# \\ 2.2500 & 1.55591 \# \\ 2.2500 & 1.63706 \# \\ 4.5000 & 2.92646 \\ 4.5000 & 2.67574\end{array}$

$86.80 / 95.83 * *$

2.67574

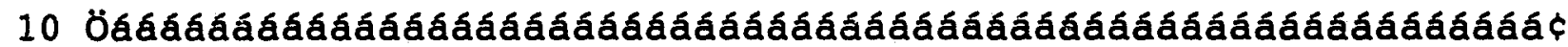
${ }^{\circ} \mathrm{SLOPE}=1.2976$

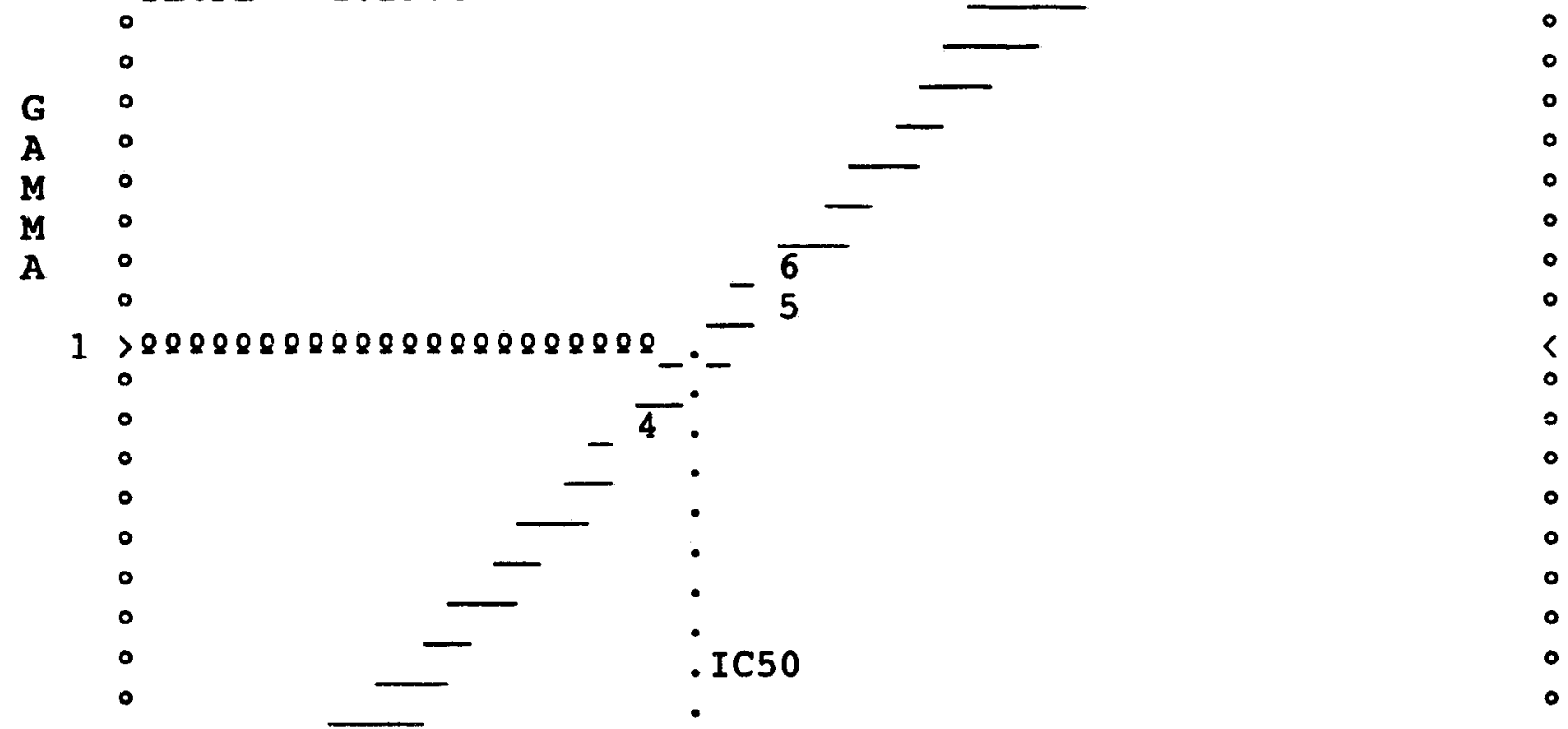

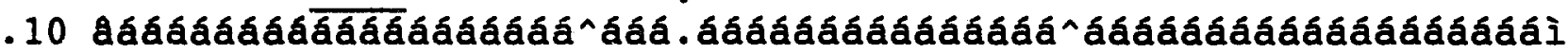
.100 1 CONCENTRATION 10 100

IC50 1.5694 (958 CONFIDENCE RANGE: 1.4896 TO 1.6536$)$ 
STATISTICAL REPORT IFOR DATA FILE 950427A1.K1

ESTIMATING EQUATION: LOG $\mathrm{C}=0.7687 \times$ LOG $\mathrm{a}+0.1957$

NUMBER OF DATA PAIRS USED: 4

RESIDUAL VARIANCE: 0.00011

$95 \%$ CONFIDENCE FACTOR: 1.05362 FOR IC50

CORRELATION COEFFICIENT: $R=0.99877$

COEFFICIENT OF DETERMINATION: $R^{\wedge} 2=0.99755$

INHIBITING CONCENTRATIONS (95\% CONFIDENCE RANGE):

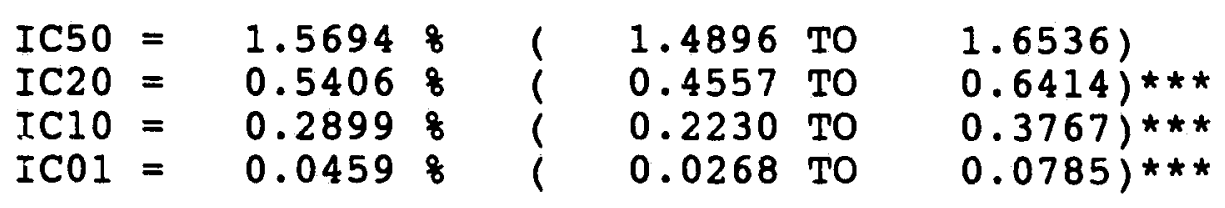

** EXTRAPOLATED RESULTS 
FILE NAME: 950427A1.K15

Investigator:

Sample Description: COOP Ref.,Effl. from API Sep,, pH=adj. Procedure: BASIC Initial Concentration : 4.5 \& Test Time: 15 minutes NUMBER

-1
2
3
4
5
6
7
8

CONTROL IT/IO $=$ RATIOS =
IO/IT

$97.66 / 65.42$

$96.29 / 62.17$

$94.93 / 40.67$

$92.83 / 49.61$

$91.97 / 27.80$

$91.63 / 27.42$

$93.70 / 15.50$

$95.02 / 17.63$
$84.55 / 93.48$
TEST DATE:

TEST TIME:

Approved by:
CONC.

$\begin{array}{ll}0.5625 & 0.35873 \# \\ 0.5625 & 0.40971 \# \\ 1.1250 & 0.77529 \# \\ 1.1250 & 0.70313 \# \\ 2.2500 & 2.01113 \# \\ 2.2500 & 2.04157 \# \\ 4.5000 & 4.50220 \# \\ 4.5000 & 3.90559 \#\end{array}$

$87.77 / 95.83 *$ *

$0.9159 * *$

DATA REPORT

CORRECTION FACTOR $=0.9102$

Osmotic Adjustment: MOAS

Dilution Factor : 2 Concentration Units: 8

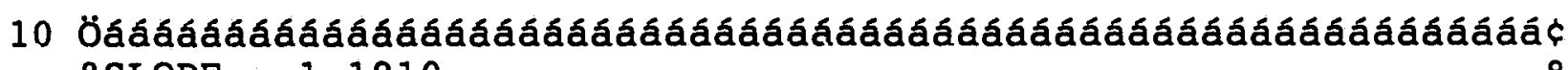

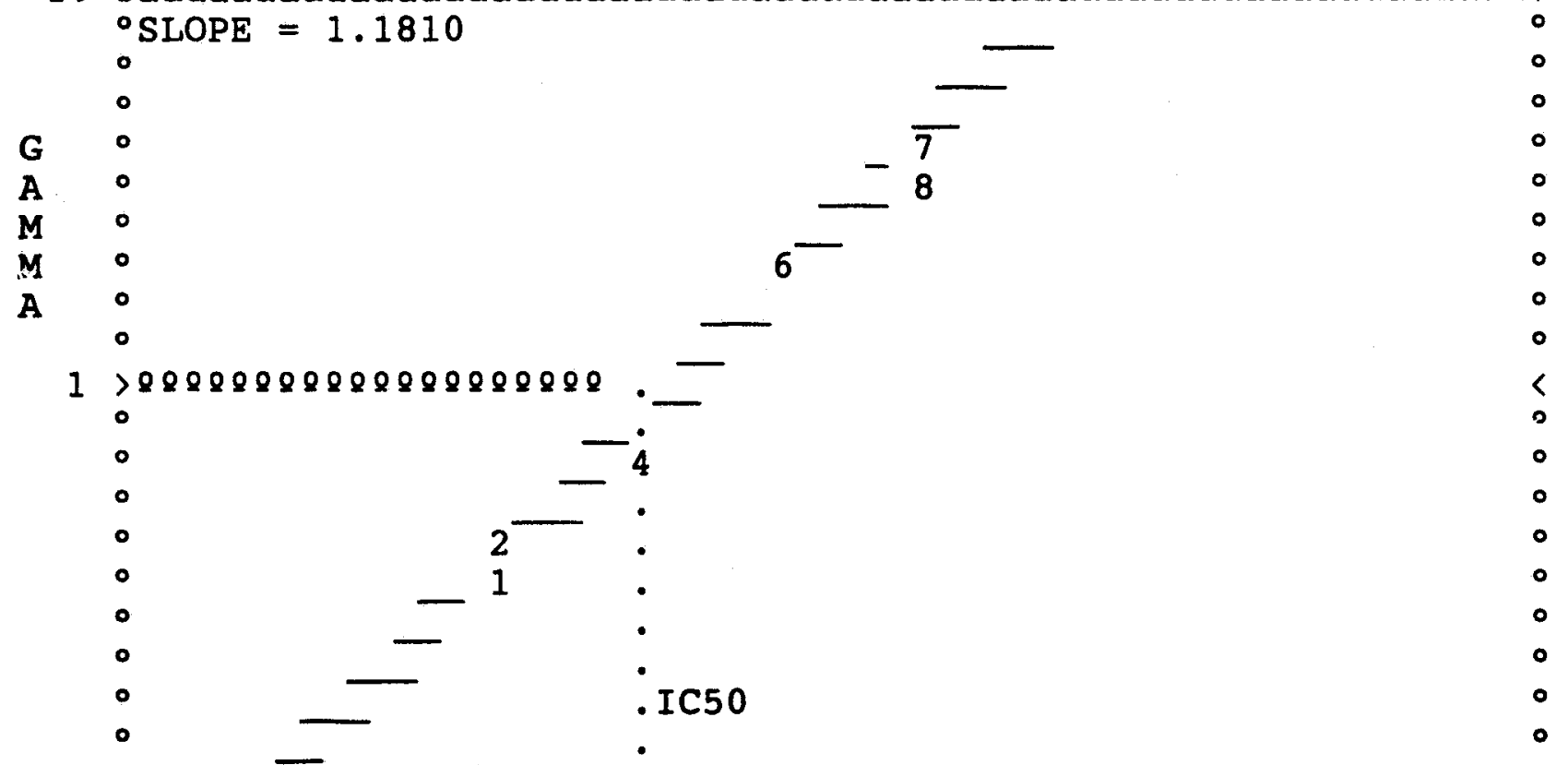

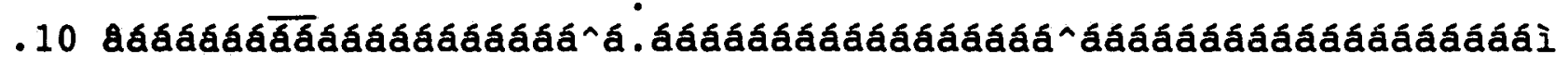
.100

1 CONCENTRATION 10

100

IC50 1.3237 (958 CONFIDENCE RANGE: 1.2230 TO 1.4327 )

\# Used for calculations 
ESTIMATING EQUATION: LOG $C=0.8383 \times$ LOG $\bar{a}+0.1218$

NUMBER OF DATA PAIRS USED: 8

RESIDUAL VARIANCE: 0.00149

$95 \%$ CONFIDENCE FACTOR: 1.08235 FOR IC50

CORRELATION COEFFICIENT: $R=0.99504$

COEFFICIENT OF DETERMINATION: $R^{\wedge} 2=0.99011$

INHIBITING CONCENTRATIONS (958 CONFIDENCE RANGE):

\begin{tabular}{|c|c|c|c|c|c|c|}
\hline $\begin{array}{l}I C 50 \\
I C 20 \\
I C 10 \\
I C 01\end{array}$ & $\begin{array}{l}= \\
=\end{array}$ & $\begin{array}{l}1.3237 \\
0.4140 \\
0.2098 \\
0.0281\end{array}$ & $\begin{array}{l}q \\
8 \\
8 \\
8\end{array}$ & $\begin{array}{l}1.2230 \\
0.3546 \\
0.1690 \\
0.0186\end{array}$ & $\begin{array}{l}\text { TO } \\
\text { TO } \\
\text { TO } \\
\text { TO }\end{array}$ & $\begin{array}{l}1.4327) \\
0.4834) \star \star \star \star \\
0.2605) \star \star \star \\
0.0424) \star \star \star\end{array}$ \\
\hline
\end{tabular}

*** EXTRAPOLATED RESULTS 
FILE NAME： 950427A1.K30

Investigator:

Sample Description: COOP Ref.,Effl. from Procedure: BASIC

Initial Concentration : $4.5 \%$

Test Time: 30 minutes NUMBER

IO/IT

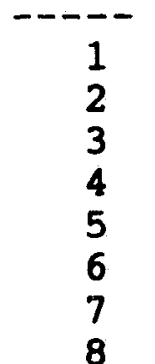

CONTROI IT/IO =

$$
\text { RATIOS = }
$$

$97.66 / 69.04$

$96.29 / 65.32$

$94.93 / 52.71$

$92.83 / 52.84$

$91.97 / 29.74$

$91.63 / 29.74$

$93.70 / 14.72$

$95.02 / 17.37$

CORRECTION FACTOR $=0.9315$
TEST DATE:

TEST TIME:

Approved by:

API Sep., pH=adj.

Osmotic Adjustment: MOAS CONC.

Dilution Factor : 2

Concentration Units: 8

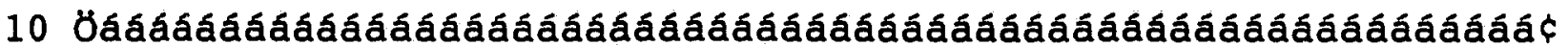

${ }^{\circ} \mathrm{SLOPE}=1.2633$

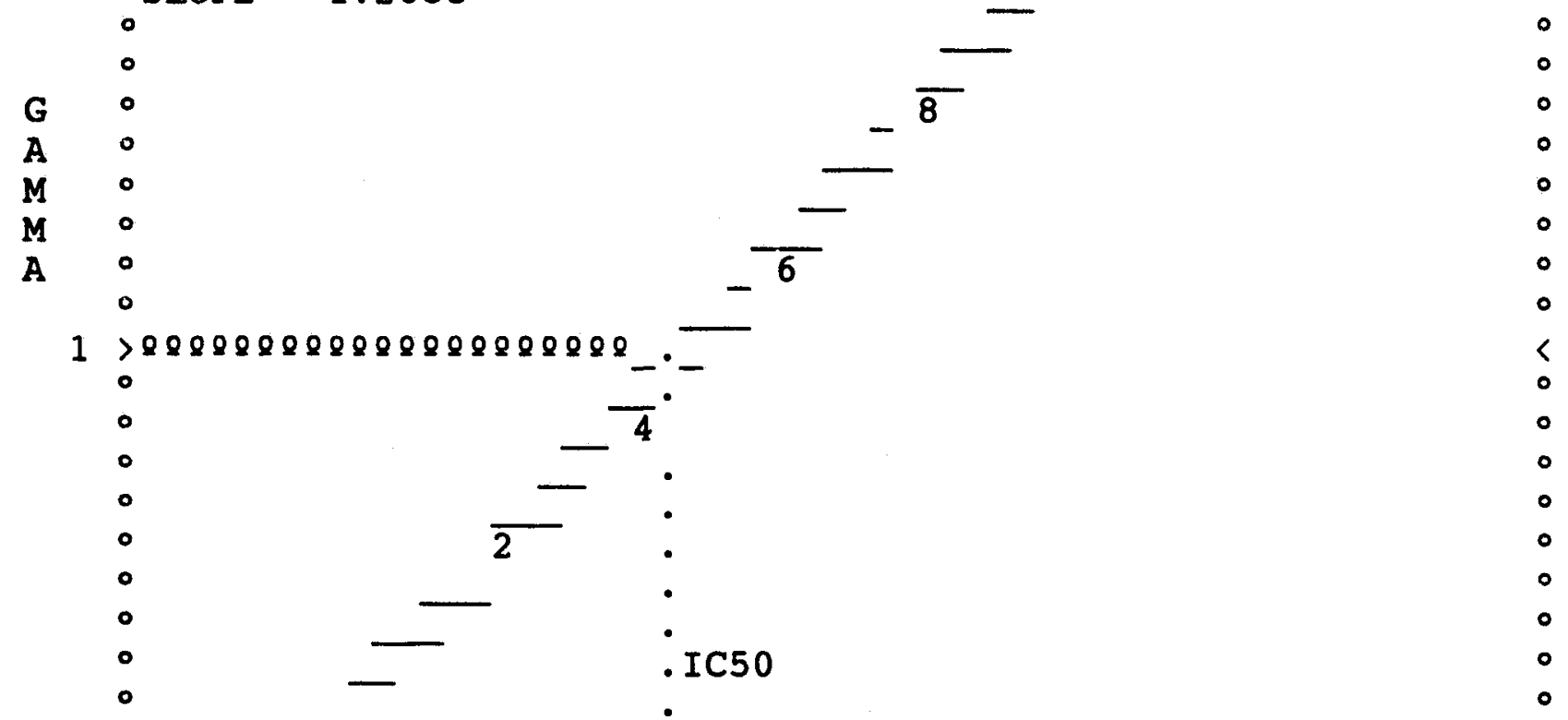

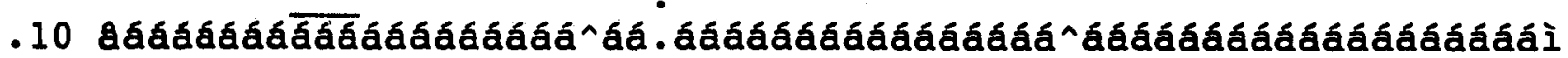
.100 1 CONCENTRATION

10

IC50 1.4027 (958 CONFIDENCE RANGE: 1.2881 TO 1.5275$)$

\# Used for calculations 
STATISTICAL REPORT FOR DATA FILE 950427A1.K30

ESTIMATING EQUATION: LOG $C=0.7823 \times$ LOG $a+0.1470$ NUMBER OF DATA PAIRS USED: 8

RESIDUAL VARIANCE: 0.00178

958 CONFIDENCE FACTOR: 1.08898 FOR IC50

CORRELATION COEFFICIENT: $R=0.99408$

COEFFICIENT OF DETERMINATION: $R^{\wedge} 2=0.98819$

INHIBITING CONCENTRATIONS (958 CONFIDENCE RANGE):

\begin{tabular}{|c|c|c|c|c|}
\hline $\begin{array}{l}I C 50= \\
\text { IC20 }= \\
I C 10= \\
I C 01=\end{array}$ & $\begin{array}{l}1.40278 \\
0.47428 \\
0.25158 \\
0.0385\end{array}$ & $\begin{array}{l}\text { l } \\
\text { ( }\end{array}$ & $\begin{array}{l}1.2881 \text { TO } \\
0.4055 \text { TO } \\
0.2022 \text { TO } \\
0.0254 \text { TO }\end{array}$ & $\begin{array}{l}1.5275) \\
0.5547)^{*} \star \star \star \\
0.3128) * \star \star \\
0.0584) * \star \star\end{array}$ \\
\hline
\end{tabular}

*** EXTRAPOLATED RESULTS 
FILE NAME: 950427E1.KI

Investigator:

Sample Description: COOP Ref., Effl. towards City, pH= adj.

Procedure: BASIC

Initial Concentration : 45 \&

Test Time: 1 minutes NUMBER

I0/IT

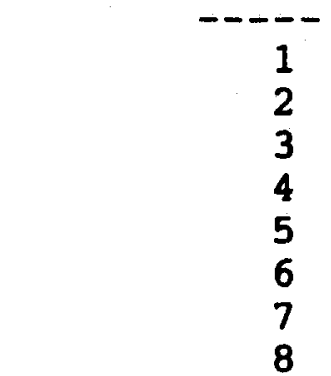

$97.34 / 83.61$

$91.80 / 70.65$

$94.54 / 63.94$

$92.09 / 46.60$
$93.60 / 77.67$

$98.60 / 76.88$
TEST DATE:

TEST TIME:

Approved by:
Dilution Factor : 2
CONC.

5.6250
5.6250
11.2500
11.2500
22.5000
22.5000
45.0000
45.0000

$84.61 / 91.96 *$ *

$0.9201 * \star$

\begin{abstract}
$87.82 / 44.41$
\end{abstract}
CONTROL ITT/IO $=$

$\begin{array}{cc}\text { RATIOS }= & 0.8805 \\ \text { CORRECTION FACTOR }= & 0.9003\end{array}$

Osmotic Adjustment: MOAS

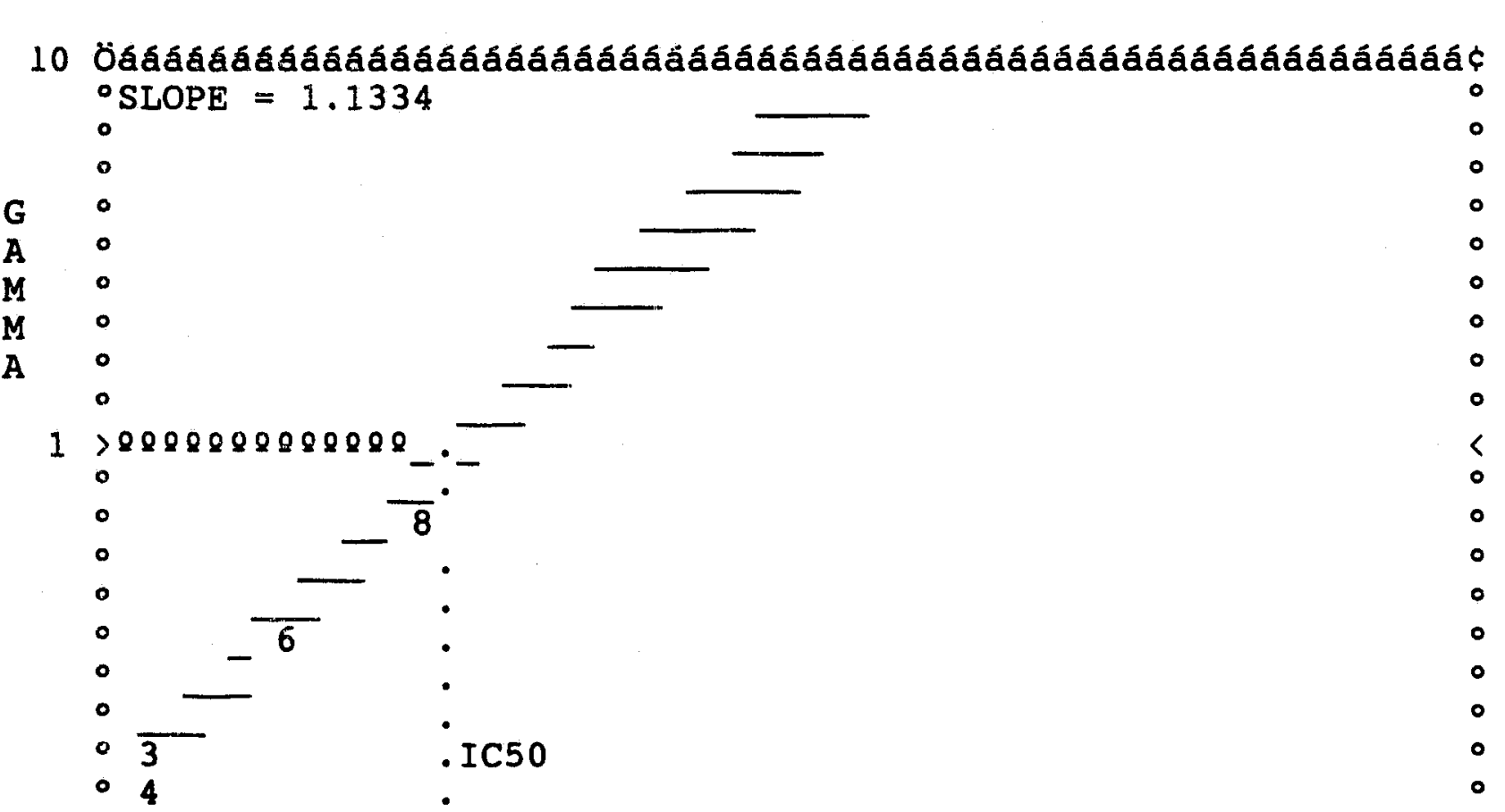

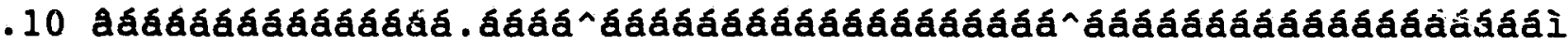
10 100 CONCENTRATION 1000

IC50 55.4242 (958 CONFIDENCE RANGE: 48.6631 TO 63.1246) 
STATISTICAL REPORT FOR DATA FILE 950427E1.K1

ESTIMATING EQUATION: LOG $C=0.8755 \times$ LOG $\approx+1.7437$ NUMBER OF DATA PAIRS USED: 6

RESIDUAL VARIANCE: 0.00070

958 CONFIDENCE FACTOR: 1.13894 FOR IC50

CORRELATION COEFFICIENT: $R=0.99614$

COEFFICIENT OF DETERMINATION: $R^{\wedge} 2=0.99229$

INHIBITING CONCENTRATIONS (958 CONFIDENCE RANGE):

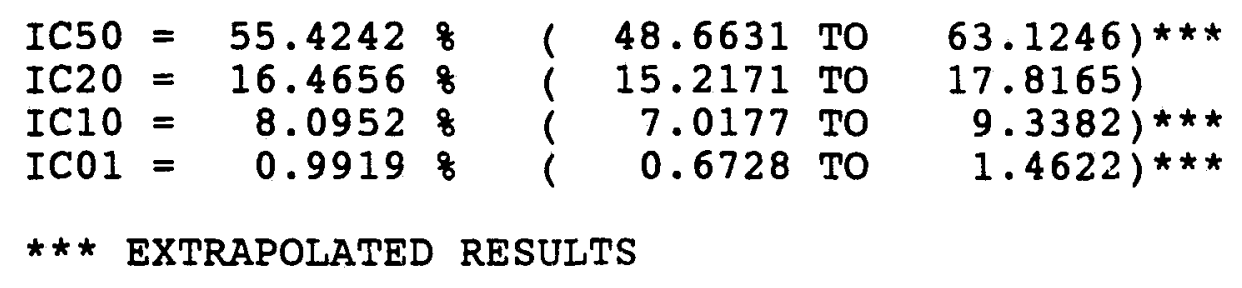


MICROTOX DATA REPOR!

FIIE NAME: 950427E1.K15

TEST DATE:

TEST TIME:

Investigator:

Approved by:

Sampie Description: COOP Ref., Effi. towards City, pH=adj.

Procedure: BASIC

Initial Concentration : $45 \%$

Test lime: 15 minutes

NUMBER

IO/IT

CONC.

Osmotic Adjustment: MOAS

Dilution Factor : 2

$\begin{array}{cc}1 & 93.60 / 77.03 \\ 2 & 97.34 / 80.93 \\ 3 & 91.80 / 67.97 \\ 4 & 98.60 / 73.94 \\ 5 & 89.21 / 54.50 \\ 6 & 94.54 / 60.65 \\ 7 & 92.09 / 43.80 \\ 8 & 87.82 / 42.90\end{array}$

CONTROL IT/IO $=80.23 / 93.03$

RATIOS $=0.8624$

CORRECTION FACTOR $=0.8815$

Concentration Units: 8

GAMMA

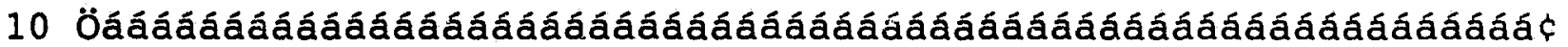
${ }^{\circ} \mathrm{SLOPE}=1.0899$

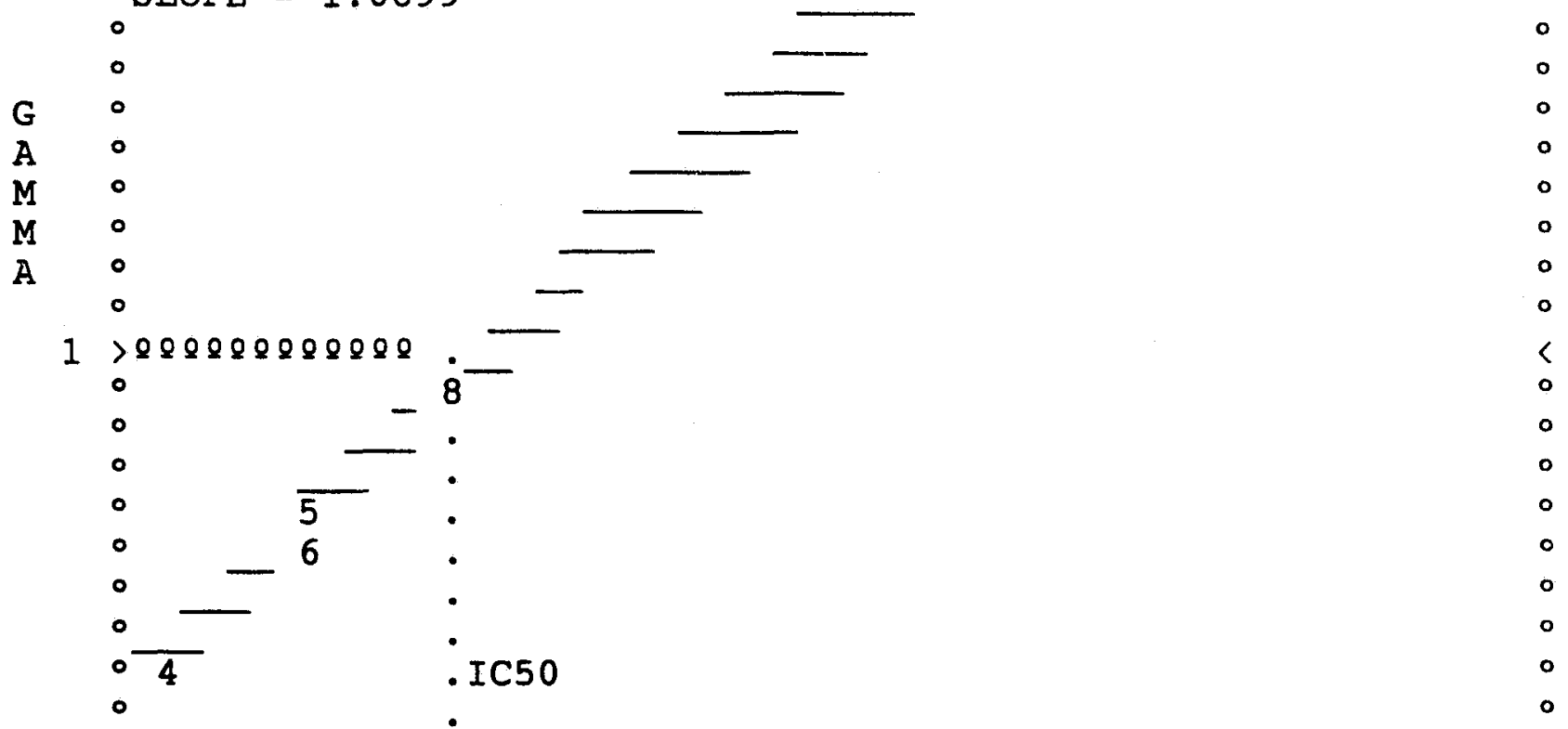

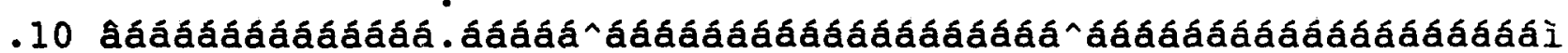

10

100 CONCENTRATION 1000

10E 4

IC50 52.3195 (958 CONFIDENCE RANGE: 45.5553 TO 60.0881 )

\# Used for calculations 
ESTIMATING EQUATION: LOG $\mathrm{C}=0.9087 \times$ LOG $\mathbf{a}+1.7187$

NUMBER OF DATA FAIRS USED: 6

RESIDUAL VARIANCE: 0.00087

958 CONFIDENCE FACTOR: 1.14848 FOR IC50

CORRELATION COEFFICIENT: $R=0.99520$

COEFFICIENT OF DETERMINATION: $\mathrm{R}^{\wedge} 2=0.99043$

INHIBITING CONCENTRATIONS (958 CONFIDENCE RANGE):

$$
\begin{aligned}
& \text { IC50 }=52.3195 \%(45.5553 \text { TO } 60.0881) * * * \\
& \text { IC20 }=14.8438 \text { \% (13.4912 TO 16.3319) } \\
& \text { IC10 }=7.1039 \text { \& }(5.9629 \text { TO } 8.4633) * * * \\
& I C 01=0.8038 \%(0.5068 \mathrm{TO} \quad 1.2747) * \star *
\end{aligned}
$$


FILE NAME: $950427 \mathrm{E} 1 . \mathrm{K} 30$

Investigator:

Sample Description: COOP Ref., Effl. towards City, $\mathrm{pH}=$ adj. Procedure: BASIC

Initial Concentration : 45 \%

Test Time: 30 minutes NUMBER

IO/IT

$\begin{array}{cc}-- & -\cdots \\ 1 & 93.60 / 72.11 \\ 2 & 97.34 / 77.69 \\ 3 & 91.80 / 65.35 \\ 4 & 98.60 / 71.01 \\ 5 & 89.21 / 53.05 \\ 6 & 94.54 / 58.45 \\ 7 & 92.09 / 41.94 \\ 8 & 87.82 / 40.89\end{array}$

CONTROL IT/IO $=79.00 / 93.03$ RATIOS $=0.8492$

CORRECTION FACTOR $=0.8704$
GAMMA

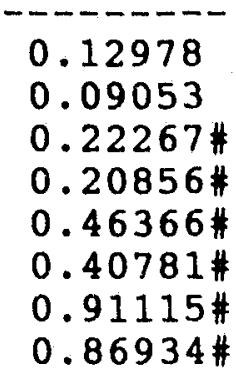

TEST DATE:

TEST TIME:

Approved by:

Osmotic Adjustment: MOAS

Dilution Factor : 2

CONC.

Concentration Units: 8

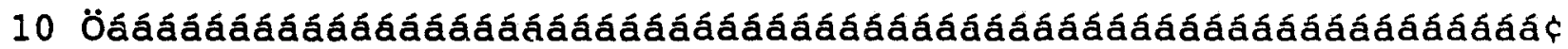

${ }^{\circ}$ SLOPE $=1.0231$

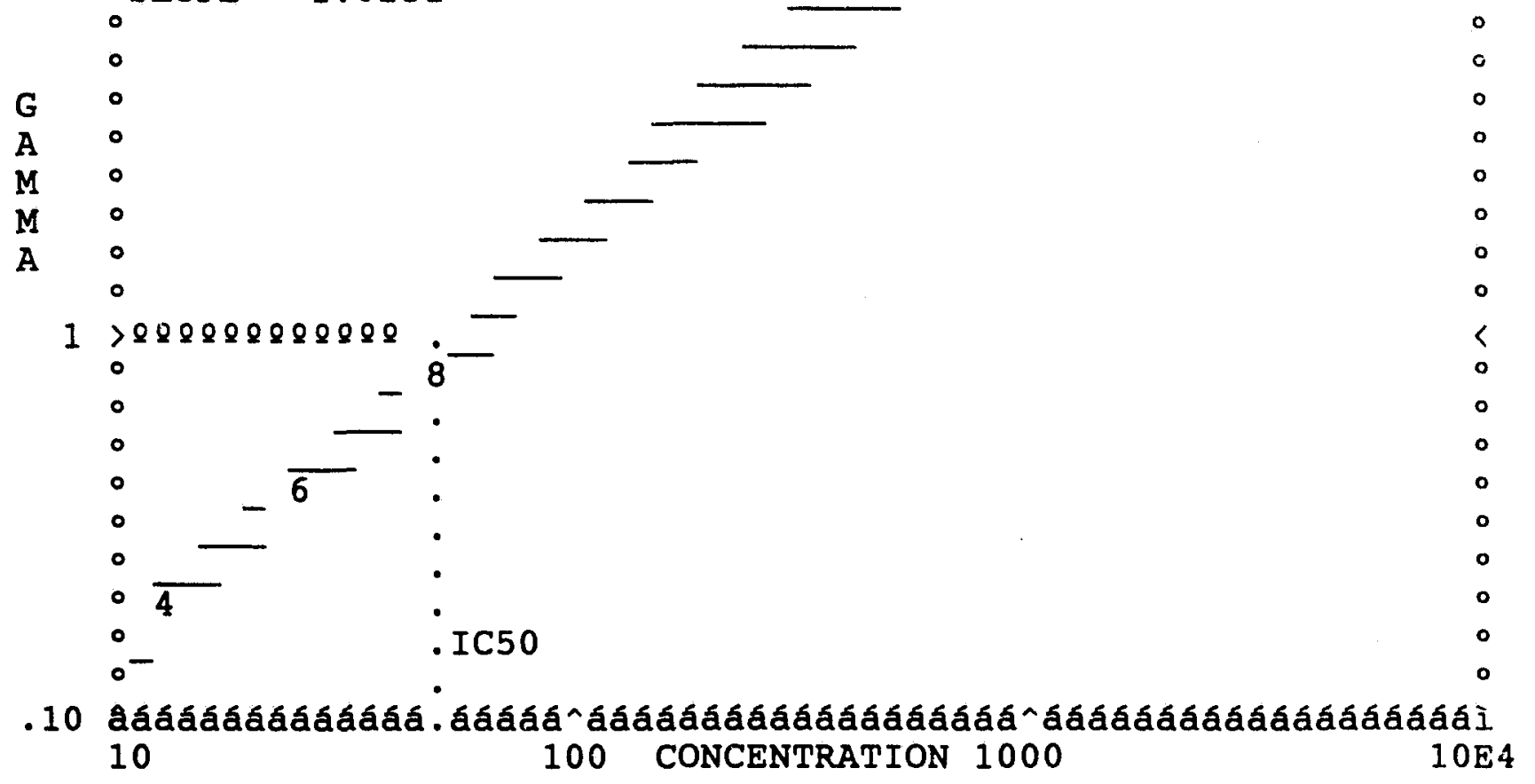

IC50 50.3132 (958 CONFIDENCE RANGE: 45.3696 TO 55.7954)

\# Used for calculations 
ESTIMATING EQUATION: LOG $\mathrm{C}=0.9719 \times$ LOG $\tilde{\mathrm{a}}+1.7017$

NUMBER OF DATA PAIRS USED: 6

RESIDUAL VARIANCE: 0.00052

$95 \%$ CONFIDENCE FACTOR: 1.10896 FOR IC50

CORRELATION COEFFICIENT: $R=0.99714$

COEFFICIENT OF DETERMINATION: $\mathrm{R}^{\wedge} 2=0.99429$

INHIBITING CONCENTRATIONS (958 CONFIDENCE RANGE):

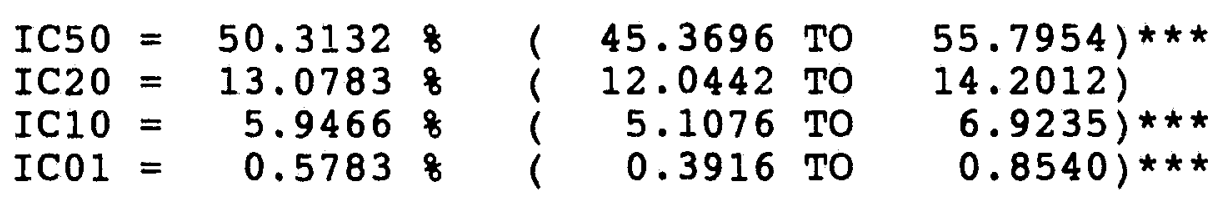

** * EXTRAPOLATED RESULTS 